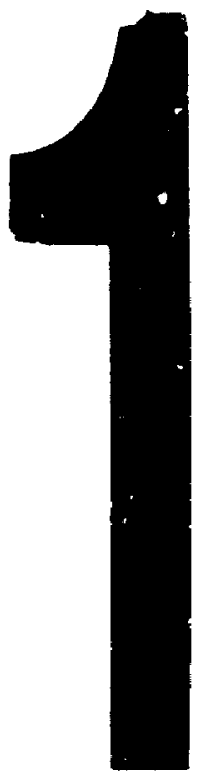

PM-1 3' $\times$ 4 PHOTOGRAPHIC MICROCOPY TARGET NBS 1010a ANSI/ISO \#2 EQUIVALENT

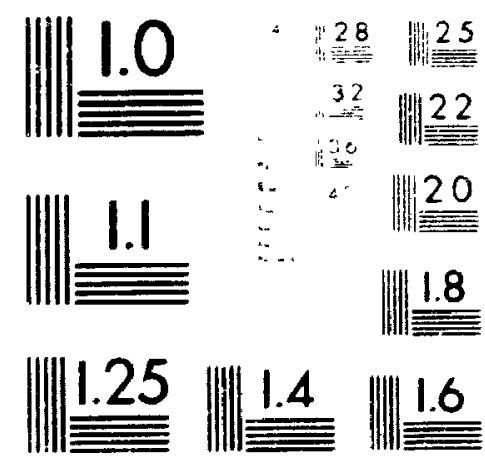

PRECISIONSM RESOLUTION TARGETS 
The quality of this microform is heavily dependent upon the quality of the original thesis submitted for microfilming. Every effort has been made to ensure the highest qua'ity of reproduction possible.

If pages are missing, contact the university which granted the degree.

Some pages may have indistinct print especially if the original pages were typed with a poor typewritor ribbon or if the university sent us an inferior photocopy.

Reproduction in full or in part of this microform is governed by the Canadian Copyright Act, R.S.C. 1970, c. C-30, and subsequent amendments.
La qualité de cette microforme dépend grandement de la qualité de la thèse soumise au microfilmage. Nous avons tout fait pour assurer une qualité supérieure de reproduction.

S'il manque des pages, veuillez communiquer avec l'université qui a conféré le grade.

La qualité d'impression de certaines pages peut laisser à désirer, surtout si les pages originales ont été dactylographiées à l'aide d'un ruban usé ou si l'université nous a fait parvenir une photocopie de qualité inférieure.

La reproduction, même partielle, de cette microforme est soumise à la Loi canadienne sur le droit d'auteur, SRC 1970, c. C-30, et ses amendements subséquents. 


\title{
Sino-Soviet Relations During The Gorbachev Era
}

\author{
by \\ Joan Xiuzhen Zhao
}

A thesis submitted to the Faculty of Graduate

Studies in partial fulfilment of the requirements

for the degree of Master of Arts

Institute of Central/East European

and Russian-Area Studies

Carleton University

Ottawa, Canada

March 231994 
Acquisitions and

Bibliographic Services Branch

395 Wellington Sireet

Ontawa. Ontarto

KIA ON4
Direction des acquisitions ef

des services bibliographiques

395. rue Wellington

Ottawa (Ontaro)

KIA ONA
The author has granted an irrevocable non-exclusive licence allowing the National Library of Canada to reproduce, loan, distribute or sell copies of his/her thesis by any means and in any form or format, making this thesis available to interested persons.
L'auteur a accordé une licence irrévocable et non exclusive permettant à la Bibliothèque nationale du Canada de reproduire, prêter, distribuer ou vendre des copies de sa thèse de quelque manière et sous quelque forme que ce soit pour mettre des exemplaires de cette thèse à la disposition des personnes intéressées.

L'auteur conserve la propriété du droit d'auteur qui protège sa thèse. Ni la thèse ni des extraits substantiels de celle-ci ne doivent être imprimés ou autrement reproduits sans son autorisation.

ISBN $\quad 0-315-92928-6$ 
Name $2 H A C$ Jian xiuzhen

Dissertation Abstracts International is arranged by brood, general subject categories. Please select the one subject which most nearly describes the content of your dissertation Enter it : corresponding four-digit code in the spaces providud

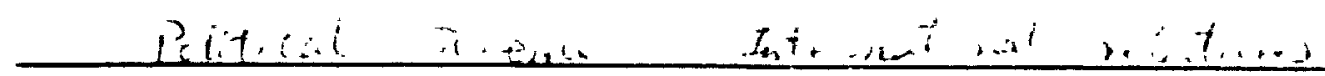
SUBSECT TERM

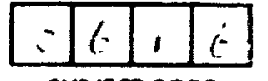

SUAJECT CODE

\section{Subject Catogories}

\section{THE MUMANImES ANo Social sciences}

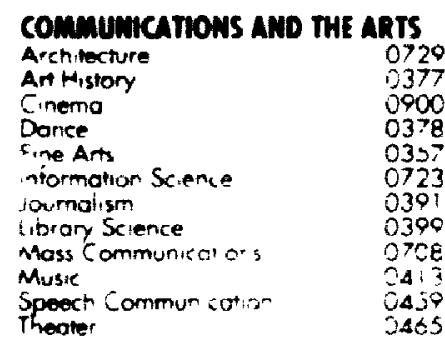

\section{EDUCATION}

\section{General}

Adr: astratice:

Aribl ond Conim $=9$

Aor cultura

A

Bil nguat and Mulniculita

Business

Gomimuir Gotrege

Eoly Chidhood

Elemertion

En-ce

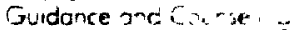

trooith

Hather

Hotory of

industri

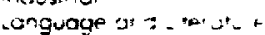

Mothemat :s

Music

Prilosoping

Psycholagy
Reading
Re'igious
Sciences
Secondary
Social Sciences
Sociologr of
Spectal
Teacher Training
Technotogy
Tests and Meosurements
Vocational

0525
0.535
0.27
0714
0533
05.4
0340
0527
0536
0716
0288
0.74

UMGUACE, UTERATURE AND IHOHSTICS

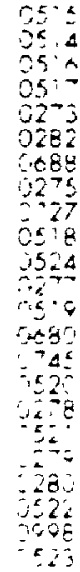

antient

+ngsuses

Mogen-

: taration

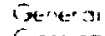

C.sssica

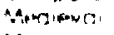

Moder-

Atrecon

Americor

A. or

Smata frg at

Erais

rerror

ir - Gma ,

momance
PHILOSOPHY, RELGION ANO

\section{THEOLOGY}

Philosophy
Religion

Generol

Biblical Studie

Clergy

History of

Philosophy of

Theology

\section{SOCIN SCIENCES}

Americon Studies

Anthropology

Archaeologe

Culura

Nidale Ezimer
Exsiness Admin station

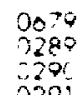

Genero

Accounting

Bomking

Marogemen.

Murke"ing

Comerdean Sterios

Economirs

enenera

Azriculata

mmers 6.sions.

Fured

Hescosing

suter

imarer

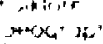

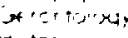

an.
0422

0318

0321

0379

, 322

0460

0,323

0324

0326
0.327

0310

는?

5454
.338

0338

$350:$

0505

0509
.508

0509

05

358

351

$5 e$

\section{THE SCIENCES AND ENGINEERING}

\section{molockal satnces}

igricuiture

Agronomy

Agronomy

Nutrifior.

Arime Potho ugr

foud Science on:

iechnotogy

Foresty and $W$ id $\ldots$

Plant Culthe

Plant Famoing

Plant Physiatogr

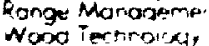

5 ology

Gerers'

Angtomy

Bostaist

Golan

Eeology

Entomales:

Genetic:

limnotogy

Micrees.jog:

Molex jior

neuroscierce

Jxeanograph,

Physiology

Padiotion

beterinary $5 x+e$

Zoology

B:ophysics

Genero

EAMTH SoEnces

brogeochemisim

Goochemisty
Seocess

coongry

reconiysist

tyorocsy

agecistar

piecistar

Falionoriogyr

Foleozwiom

Parmology

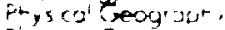

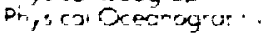

MEAITH ANC ENVIRONMENTAL

SCIENCES

Ene oomeres sorian ids

Anoglet toremes

senirez

Audingr

byortister.

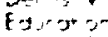

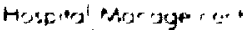

to mne reveloomare

lmim jionsyy

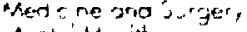

Auntgi Heoriti

itustirs,

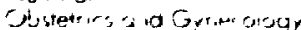

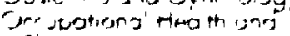

Thergoy

Sphthalmosogy

Eutrology

Phormac soayy

Phirmact

Phyicat Therocor

Public Heolit

Rodiologr
Recreation

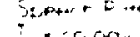

ane tersetit

\section{PHYSICAL SCIENCES}

Pure Sciences

nom siry

Agerir vit.

Arapien

triegrar

iuriece

seture

ftoumare it

Physicesl

Polymer

Arthemgics

Prisire:

Cenartat

Arousits

Asirrinomy ard

Asteoptysirs

Amospheric Scienco

Atom:

Electronic: and Elerte -it

Elementrory Purtittes orit

Hath Energy

Furdoria flosm

Molec ula

isur lear

Rodics

Solid Stote

inatisties

Applied Sciences

0905
Applied Mernancs

computer science

Ansent

Medieval

Modern

Black

Afriran

033

o and foredris 0332

Ernodiar

Europeon

Latrin Americar

Middle Easter

History of Science

Low

Polifical Science

Genera

international law and

Relotions

Fuvile Admimistration.

Fecreation

Soctal Work

Sociology

Tenera:

Eriminology ur a fenzicgy

Demography

Ethnic and Rar oi Stuates

individua and Fam ir

Sturdies

industrini and gbe.

Relations

Fubir and 50 a woiket

Socol Struchuse a re

Developmen'

Theory arin Metteri,

irmsectation

stirar ard Feger

'A5':

28

Exy, near 's

acerers

Agriculiuro

Automat.

E.omec $: 0$.

Comica

ris

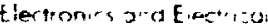

Hed and ithermogynam.es

Hyaraulis

industrizi

Marne

Moteria: 'se 6 .

Mechonica!

Metoll Jrgr 
The undersigned recommend to the Faculty of Graduate studies and Research acceptance of the thesis

\section{SINO-SOVIET RELATIONS DURING THE GORBACHEV ERA}

submitted b:- Joan Xiuzhen Zhao, B.A. in partial fulfilment of the requirements for the degree of Master of Arts
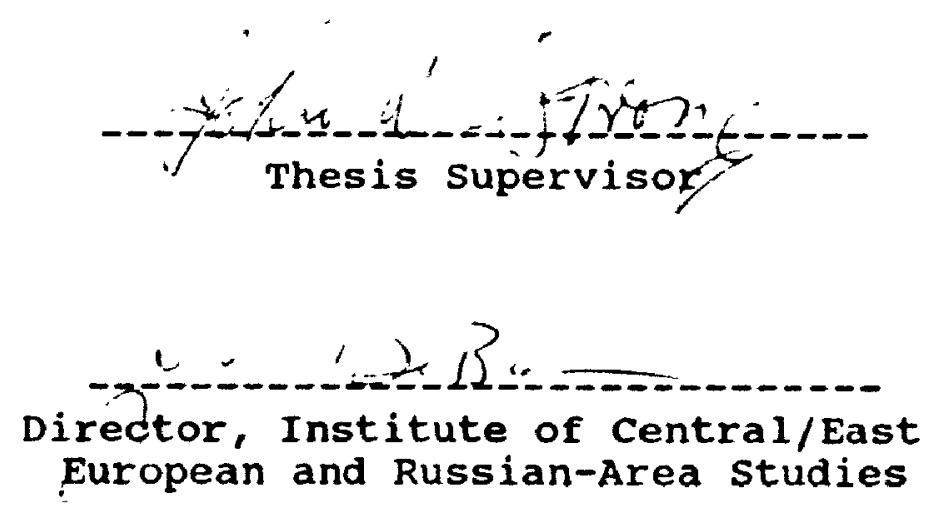

Carleton University

April 1994 


\begin{abstract}
During the period of 1949 to 1985 , sino-soviet relations went through a zigzag course. The fraternal bilateral relations during 1950-1956 turned into a gradual deterioration under Khrushchev's administration. In Brezhnev's era, the continuance of the sino-soviet split led to border clashes in 1969. Sino-Soviet relations under the Andropov and Cherenenko periods were characterized by stand-still unfavourable relations with low-tone contacts between two countries.

It was not until Gorbachev's rise to power that the issue of normalization of sino-Soviet relations came true. However, before the completion of normalization, Moscow had to address "the three obstaclis" put forward by China. The long process of negotiations for sino-Soviet normalization finally led to the sino-Soviet Summit in May 1989, which signified the ending of abnormal relations and the opening of a new stage in bilateral relations.

The Sino-Soviet economic relations during Gorbachev's era had moved ahead of political relations. Both sides had engaged in economic cooperations long before Moscow completely addressed "the three obstacles". The economic contacts were complementary, based on the self-interest of both sides. The border trade played an important role in sino-soviet economic ties.
\end{abstract}

The Beijing Summit led to the development of improved political and economic relations between china and the soviet Union. 


\section{ACKNOWLEDGEMENTS}

My thanks are due to Professor John w. Strong, my thesis supervisor, who checred the whole paper, suggested numerous corrections and improvements.

I am most grateful to Professor Marilyn Marshall, Dean of the Faculty of social sciences, for her support and encouragement.

I owe a special debt of gratitude to Mrs. Donna Harper, for her help and kindness to me.

During my study, help and advice from many scholars ard students in Institute of Central/East European and RussianArea studies are greatly appreciated. 


\section{DEDICATION}

I wish to dedicate the paper to my husband, Hanje, for his help, encouragement and trust in my life. Without him, it would be impossible for me to complete my study. 


\section{TABLE OF CONTENTS}

I. Introduction -

II. Chapter One: Historizal Review

1. Introduction---

2. Sino-Soviet Relations During Stalin's Era -.....- 15

3. Khrushchev's Foreign Policy and Response From CCP

4. Several Issues During the Conflict $-20-2$

5. Relations During the Brezhnev

6. The Border Issues and the 1969 Border clashes - -31

7. The Initial stage of Normalization of Sino-Soviet Relations --

8. Relations During the Periods of Andropov and Cherenenko -

9. Conclusion -

III. Chapter Two: Bilateral Relations During Gorbachev's Era 1. Introduction - -

2. Soviet Foreign Policy Toward China -

3. China's Foreign Policy Toward the Soviet Union --- 61

4. The Process of Normalization of Sino-Soviet Relations

5. Political Consultations -

6. The Three Great Obstacles a). Soviet Forces Along the Sino-Soviet Border and Mongolia -- Al- 75

b) . Afghanistan -

c). Vietnam-Kampuchean Conflict -

7. Border Dispute -

8. Further Negotiations Towards Normalization -..--- 85

9. May 1989 Beijing Summit ....... 88

10. Implication of Sino-Soviet Normalization - - - 90

VI. Chapter Three: Sino-Soviet Economic Relations

1. Brief History Review of Sino-Soviet Economic Relations -

2. A New Stage of Economic Relations --_-_-_-_- 102

3. The Joint Soviet-Chinese Commission -

4. Foreign Trade -

5. Construction and Transformation of Industrial Projects -..-...- 116

6. Border Trade -

7. The Advantages of Sino-Soviet Economic Cooperation

8. Problems Existing in Sino-Soviet Economic Cooperation

8. Problens Existing in sino-soviet Econ- 125

7. Conclusion - 127 
V. Chapter Four: Sino-Soyiet Relations After 1989's Summit

1. Soviet Reaction to Tiananmen Square's Event -- - 129

2. The Changes in the Eastern Europe and its Impact on China - 132

3. Actual Process in Bilateral Relations -

4. Visits by $I i$ Peng in April 1990 and Jiang Zeming In May 1991 -

5. Bilateral Economic Relations After the Summit -- 142

VI. Conclusion

VII. Bibliography

VII. Tables

Table 1. Planned Projects in China during the First

Five-Year Plan (1953-1957) -

Table 2. Sino-Soviet Trade, 1950-1964

Table 3. Soviet Trade with China, 1965-19\%4

Table 4. Soviet Forelgn Trade Turnover with China (1980-1984) - 101

Table 5. Soviet Foreign Trade, 1980-1985

Table 6. Soviet Foreign Trade Turnover with china (1985-1990)

Table 7. Soviet Foreign Trade, 1986-1990 


\section{INTRODUCTION}

From 1949 when the People's Republic of China was founded to 1991, the time of the collapse of the Soviet Union, SinoSoviet relations had gone through four major stages. In the early 1950s, China and the Soviet Union formed a fraternal alignment against the West, especially the United states. However, the late 1950 s saw the beginning of a historic split between them. The split occupied a central place in international politics, and reached its height in the 1969 border clashes over disputed islands in the Ussuri River.

For strategic reasons, China changed its foreign policy by an alignment with the united states in the early 1970s. The final normalization of Sino-American relations in 1979 altered the strategic setting in international political arena, and led to formation of a de-facto sino-American alliance against. the Soviet Union. Since then, sino-Soviet relations fell into a long "chilling time" until the rise of Mikhail Gorbachev as General Secretary of the Communist Party of the Soviet Union (CPSU) in March 1985.

The 1989 Beijing summit and the final normalization of sino-Soviet relationship opened a new stage in bilateral relations. Both sides had gone through a long way toward normalization. The soviet regime had made efforts toward overcoming "the three obstacles" put by china: the reduction of Soviet troops from the sino-soviet border and the remover of Soviet troops from Mongolia; the withdrawal of soviet 
troops from Afghanistan; and the elimination of soviet political support and military aid to vietnam's occupation of Kampuchea.

During the early period of 1949-1952, the main priority for Chinese leaders was domestic concerns rather than international politics. The Chinese communists found that it was urgent to lay the social foundation for the new china in order to consolidate their power. The objective of cnina's foreign policy during this period was to unify tise whole country and to defend China's border. A close alliance with communist countries, especially the soviet Union, was deemed necessary. Under such circumstances, cooperation between china and the Soviet Union was fairly smooth, even though Josef stalin was hostile to Mas zedong, especially during Mao's visit to Moscow from December 1949 to January 1950. Although a number of trade and economic agreements concluded at that time were inequitable, China had to sign with the soviet Union, as no other sources of aid were available to china on such a large scale. The soviet aid did help in creating the foundations for the Chinese economy, and thus, Mao's personal resentment of stalin was carefully hidden.

Nikita Khrushchev's new foreign policy - one of peaceful co-existence with the West, and his destalinization program begun in 1956, faced overwhelming opposition from China, because of Mao's special position in the communist movement, on the one hand, and because of different outlooks and 
interests between the two countries, on the other. In the late 1950 s Sino-soviet relations grew worse.

There were several factors which contributed to the $r$ ift in sino-Soviet relations. One was the different outlooks or idenlogical issues. Mao opposed Khrushchev's pnlicies, when the latter denounced the personality cuit of stalin and adopted a policy of detente with the United states. By the mid 1950s, Mao had shaped his own personality cult inside China. Thus, by defending stalin's personality cult, Mao was defending himself. Mao also opposed Khrushchev's peaceful coexistence with the West, because of his strong sense of anti-Americanism. On the economic scene, the chinese policy of "the Great Leap Forward" (which was Mao's attempt to speed up China toward communism through forced industrial development) was criticized by the soviet regime as a misunderstanding of communism.' The failure of soviet relations with communist China was one of reasons for Khrushchev's removal from his post in October 1964.

Leonid Erezhnev came to power in 1964 as First Secretary of the Soviet Communist Party. Although the change in soviet leadership led to hopes for an improvement in sino-soviet relations, this did not materialise. In fact, relations grew worse in the late 1960s. In March 1969, there were some armed encounters between the soviet and chinese frontier guards

1 Harry Gelman. "The Conflict: A Survey", Problems of Communism. Vol. XIII, March-April 1964, p. 7 . 
along the Ussuri River (over a small disputed island known iu the Russians as Damanskii and to the Chinese as zhenbao).

Mao's death in september 1976 led to renewed speculation that sino-soviet relations would change significantly. Nevertheless, as China initially seemed to be preoccupied with its domestic political arrangements, relationship with the Soviet Union was not the main focus of its attention. With Deng Xiaoping's consolidation of his power, signs began to tmerge a possible improvement in bilateral relations.

Prior to Mao's death in 1976, there were two basic reasons why tint chinese regime opposed a detente with the Soviet Union.2 one was ideological. Mao was concerned that intimate relations with the "revisionist" soviets could contaminate the chinese revolution. The other reason was strategic. During the late 19603 to the 1970 s, the greatly increased quantity and quality of the soviet military forces along the sino-soviet border were still threatening china's security. Beijing feared a possible soviet military action against China.

Since the death of Mao, both Moscow and Beijing had exercised much greater caution in their bilateral relations. The Soviets only verbally attacked the chinese, when the Chinese-Vietnam Border War broke out in February 1979. Tre

2 Donald S. Zagoria "The Moscow-Beijing Detente", in Laird, Robbin F. and Hoffmann, Erik P. (eds.) Soviet Foreign Policy in a Changing World. New York: Aldine Publishing Company, 1986 , p. 682 . 
Chinese behaver more cautiously on the vietnam border, and there were no major incidents during the post-Mao period. The Chinese-American normalization in 1979, and Deng's established leadership and firm control added to Chinese self-confidence. By 1979, the ideological barriers to detente with the soviet Union were removed, and strategic concerns about the soviet's intention were reduced.

Since 1976 major changes in china's domestic politics and foreign policies had taken place. Under the leadership of Deng xiaoping, China began a series of radical reforms. For the first time in China's modern history, the new Chinese leaders had set economic development as the principal goal for modernization of the country. In order to achieve this goal, the country pursued a policy of opening up to the outside wcrld, and launched domestic economic reforms. They introduced "the household responsibility system" to decollectivize agriculture, expanded free market regulations and introduced foreign capitals into china. At the same time, China's foreign policy underwent significant changes. In its relations with developing countries, the chinese government reduced its ties with most national liberation movements. It cut its economic aid to developing countries by placing strong emphasis on expanding business ties with them instead.

In order to promote its "Four Moderrization Programs", Beijing needed a long-term peaceful international environment and peaceful borders. In late 1981, China began to pursue a 
new line in its foreign relatinns, one of "independent foreign policy". The policy was made clear in a speech by Chinese Premier zhao ziyang, in which he said:

China will never attach itself to any big power or group of powers, nor will it yield to any foreign pressure. ... China definitely will not enter into an alliance or strategic relationship with any big power. In other words, China will not align itself with one big power against another. ${ }^{3}$

The new line in chinese foreign policy created some hope in Moscow for a breakdown in Sino-American alignment.

In an important speech in Tashkent in March 1982, Brezhnev declared that Moscow was going to discuss the border issues with China. At the same time, he stressed that Moscow, unlike washington, did not pursue a "two-china policy". However, the Chinese were still wary. In September 1982, Hu Yaobang, clarified the fundamental differences between the Chinese and the Soviet's perspectives on foreign policy, and he still accused the soviets in pursuance of "hegemonist policy".

The Chinese regime still remained wary of Moscow, because it viewed the Soviet policy toward China as only a tactical shift within a general and continuing commitment to the Brezhnev policy in Asia. The Soviet's political and military

${ }^{3}$ Ziyang 2hao. "The Objectives of China's Foreign Policy: For Lasting Peace, Increased Friendly Cooperation, and coprosperity", International Affairs. (Great Britain) Vol. 61, No. 4, Autumn 1985 , p. 578 .

4 Yaobang Hu. "Create A New Situation in All Fields of Socialist Modernization -- Report to the 12 th National Congress of the Communist Party of China", Beijing Review. Vol. 25, No.37, September 13, 1982, p. 33. 
encirclement of China continued. Beijing and Moscow had different views over Afghanistan as well as southeast and northeast Asia, areas which were of great importance to China's security. Thus, chinese leaders kept their distance from the Soviet Union, and still tilted toward the United states. Before china would consider normalization of sinoSoviet relations, Moscow had to address the china's earlier declaration of "the three obstacles".

From the Fall of 1982 to the emergence of Gorbachev in March 1985, contacts between Beijing and Moscow increased gradually. Five rounds of semi-annual meetings on the level of deputy foreign ministers were held. This substantial process paved a way for future institutionalization of bilateral relations.

When Gorbachev came to power in March 1985, his vision of international politics and of how the Soviet Union should perform as a superpower in the new international environment had changed.' Gorbachev radically changed the concept of Soviet national security. Fundamental issues such as what was national security, and how should the sovist Union act as a superpower, were raised. According to Gorbachev's thinking, military power alone was not sufficient for national security. National and mutual security, especially relating to sovietAmerican relations, were closely connected. In his speech to

5 Robert Legvold. "The Revolution in Soviet Foreign Policy", Foreign Affairs: America and the World 1988/1989. Vol.68, No.1, 1988/1989, pp. 86-87. 
the 27th Party Congress in February 1986, Gorbachev said:

The nature of current weaponry leaves no state with any hope of defending itself using solely military-technical means- through the creation of a defense. ... Ensuring security is becoming more and more a political task, and it can be accomplished only by political means.

The Soviet leader realized that in the present era, most threats to national security and prosperity were economic and political instead of military. The possession of military power provided little solution to these threats.

A second changed concept was Gorbachev's deep conviction that no nation's security can be achieved at the expense of another nation. As Gorbachev stated:

Security, if we are talking about welations between the USSR and the U. S. can only be mutual, and if we take international relations as a whole, it can only be universal. ... It is necessary that everyone feel equally secure, since the fears and anxieties of the nuclear age give rise to unpredictability in policies and concrete actions.?

From the very beginning, Gorbachev sought to improve relations with China as an important element in his effort to revise soviet foreign policy. In a speech in July 1986 in Valdivostok, Gorbachev spoke about the Soviet policy in Asia."

6. M. Gorbachev. "The Political Report of the CPSU Central Committee to the 27 th Congress of the communist Party of the Soviet Union", Pravda and Izvestiia, February 26, 1986, pp. 2-10. Text is translated in The Current Digest of The Soviet Press. (hereafter, CDSP) Vol. XXXVIII, No. 8, March 26, 1986, p. 27 .

7 Ibid.

- For the whole content, see, "Speech by Comrade M.S. Gorbachev at the Ceremonial Mceting Devoted to the Presentation of the Order of Lenin to vladivostok" " Pravda and Izvestila, July 29, 1986, pp. 1-3. Text is translated in CDSP. Vol. XXXVIII, No. 30, August 27, 1986, pp. 1-8, 32 . 
He talked about an all-Asian approach to regional security that could be based on the model of the Helsinki Agreement; announced greater Soviet economic participation in the region; suggested that Soviet troop would be withdrawn from Mongolia and Afghanistan; declared Soviet's willingness to accept the middle channel principle of border demarcation on the sinoSoviet border; and proposed a number of joint projects between China and the Soviet Union. Gorbachev's foreign policy was welcomed by China.

Due to the failure of the centrally-planned economy, under Gorbachev's leadership the Soviet Union embarked on a path of economic reform, which in nany ways was similar to that carried out in China. It was obvious that the soviets were very interested in experiences and practices of Chinese economic reform. Since both countries had similar economic systems, it would be mutually beneficial for them to study each other's experiences. Economic ties would play a vital role in sino-soviet relations.

There are a number of books and articles covicring the history of sino-soviet relations, especially during the honeymoon period of the 1950 s and the sino-soviet conflict in the 1960s. However, there are few accounts on the whole development of Sino-Soviet relations during Gorbachev's administration, even though some articles contribute to one or another specific events. As a Chinese person interested in 
studying international relations, I am especially interested in sino-soviet relations during the Gorbachev era. Many articles on sino-Soviet relations by western specialists, such as Gerald Segal, Donald Zagoria and Robert Horn provided me with valuable sources and examples of analysis of international relations.

To be sure, sino-Soviet relations are not merely bilateral issues between the two countries. They also cover a very wide range of topics, such as relations of these two countries with the United States, the West and developing countries. Given the limited length of this paper, the paper will concentrate on sino-Soviet bilateral relations in political and economic areas. currently, due to the independence of each former Soviet republics, the name of the Soviet Union no longer exists. However, as this paper focuses on the time before the collapse of the Soviet Union, it will still use that title.

The purpose of this paper is to examine sino-soviet relations during the Gorbachev era by focusing on the political process of normalization and on the field of ecunomic cooperation. It will be argued that normalization of sino-Soviet relations is an inevitable outcome of historical developments; the emergence of a new generation of leaders in both countries which made possible reforms in domestic and foreign policies; and because of changes in the international political environment. It will also be argued that sino-Soviet 
economic relations during Gorbachev's administration are complementary. Economic ties began to develop before Moscow took steps to meet China's "three obstacles", mainly because of the economic self-interest from the both sides.

The paper consists of four chapters. The first chapter gives a historical review of sino-soviet relations, starting from the establishment of People's Republic of China in 1949. In this chapter, it explains why the sino-Soviet dispute did not break out during the stalin era, what major areas of difference were for both sides durirg Khrushchev's leadership, the border issues, and the first signs of normalization in the administrations of Leonid Brezhnev and his two successors, Yuri Andropov and Konstantin Chernenko.

The second chapter will describe a new orientation of Soviet foreign policy toward china under the leadership of Gorbachev, and the response from the chinese government. The policies of both sides will be followed by the actual processes of sino-soviet rapprochement. The response from Moscow toward "the three obstacles" and the border issues during this period will also be included in this chapter. Sino-Soviet economic cooperation and foreign trade (including barter and border trades) are main themes in Chapter Three. At the beginning of this chapter, it briefly reviews bilateral economic relations before the Gorbachev era. Then, it evaluates the advantages of bilateral economic cooperation for both sides, and discusses existing problems 
during the economic contacts.

The last chapter examines major events which happened in sino-Soviet relations after Gorbachev's visit to Beijing in 1989 .

The paper is going to be based on a historical chronological and descriptive-analyzed methodology. In other words, the paper will discuss events which happen first, and then those which happen later. The content of each chapter is divided by categories of topics, and these are then followed by an overall analysis.

The paper will mainly rely upon sources from Foreign Broadcast Information Services: Daily Report, The current Digest of Soviet Press and Keesing's contemporary Archive. The primary sources from these two countries will be such journals and newspapers as Beijing Review, People's Daily, Izvestila, Pravda, International Affairs (Moscow) and Eoreign Trade (Moscow). Other sources, such as Problems of Communism, Issues and Studies, Far Eastern Economic Review and International Affairs (London), will be important and useful sources for the paper. 


\section{CHAPTER ONE}

Introduction:

A country's foreign policy always serves its domestic requirements. Aims of foreign policy are various. It may serve to increase foreign trade for domestic industrial and agricultural needs, or serve to form military-policical allies with other countries for preventing outside threats, and so on. Decisions of foreign policy reflect perceptions of foreign policy makers, considering their country's domestic situations and its involved international environment. Thus, varying definitions of domestic and international situations lead to varying conclusions about fundamentals of foreign policy strategy and tactics.

The Sino-Soviet dispute during the mid 1950 s and the mid 1960 s did reveal these features. The sino-soviet dispute during this period was inevitable. The seeds of dispute had already been planted in the stalin era. Khrushchev's new foreign policy -- one of "peaceful coexistence" toward the West created an overwhelming opposition from China, because of Mao's special position in communist movement on one hand; and because of different outlook and interest between the soviet Union and communist china on the other hand. Thus, the following nine years had seen escalating deterioration of bilateral relations, from displute, then a conflict, and 
eventually a rift.'

The tensions of bilateral relations during the Khrushchev era did not cease but continued to escalate during Brezhnev's administration. In March 1969 the hostilities reached a peak with a series of border clashes along the Ussuri River, which was followed by accelerated military build-up by both sides along the frontier. However, from 1979 bilateral relations had gone through a slow but steady process of rapprochement. Prior to the rising of Gorbachev as new soviet leader, although the main issues of "the three obstacles" had not been solved, contacts between the two countries had provided a useful channel for further negotiaticns.

The purpose of this chapter is to review sino-soviet relations during the stalin era and the Khrushchev era, by explaining why sino-Soviet conflict did not break out during the stalin period, and depicting the factors contributing to conflict and some different outlooks and national interests on several selected issues in Khrushchev leadership. It will also examine bilateral relations during the Brezhnev era, especially emphasising border issues and 1969 March clashes. The long period of process of normalization of sino-soviet relations under administrations by Brezhnev's two successors will also be included.

- K. Zbigniew Brzezinski. The soviet Bloc: Unity And conflict. London: Harvard University Press, 1967. p. 398 . 


\section{8ino-8oviet Relations During the stalin Era:}

The historic relations between Russia and China were not good. They might be traced back to several hundred years ago, when Batu Khan overran Kievan Russian diring the 13-14th centuries, and when Imperial Russia, under the guise of "honest broker" for Britain and France, occupied Chinese north-east territory during the Manchu government administration. ${ }^{10}$ The root of sino-soviet dispute after the 1950 s had deeply embraced in Stalin's ill treatment to Chinese Communist Party (CCP) led by Mao Zedong before and after 1949 , and the historical position of CCP vis-a-vis the world in general, and the Soviet communist Party in particular.

Before 1949, Sino-Soviet relations reflected one of triangular ties -- the soviet Union, the Chinese National Government, and the Chinese Communist Party. Moscow's policy toward China was to find a political faction which would serve Soviet interest in Asia in general and its Far East in particular." Moscow's choice went to the National Government controlled by Jiang Jieshi after Sun Zhongshan's death in 1925.12 Possessing political and military force in china, Jiang's legitimate government was able to deter potential

10 John W. Strong. "Sino-Soviet Relations in Historical Perspective," in Adam Bromke. (ed.) The Communist states at the Crossroads: Between Koscow and Peking. New York: Frederick A. Praeger, 1965, p. 22-24.

"Ibid., p. 25 .

12 Donald S. zagoria. The sino-Soviet Conflict 19561961. London: Princeton University Press, 1962. p. 11. 
thereat to China and the Soviet Far East from Japan's expansionism during the 1920 s to the early 1940s. In contract, CCP, which was formally established in Shanghai in 1921, was too weak as stalin suspected, to resist Japanese force and to achieve a victory of communist revolution in backward, agriculturally-predominant china. ${ }^{13}$ Thus, to strengthen the Guomindang (GMD), Moscow, via Cominterm, ordered Chinese communists to cooperate and subordinate their political lines with Jiang's regime in the formation of the United Front. Soviet political and material aid were sent to GMD instead of CCP." But, to Jiang, the CCP was a capable and determined political faction which could overthrow his power. He could not have any accommodation with the existence of this party.

Chinese communist leaders, who were always trained by Moscow before zunyi meeting of January 1935, once tried to attack chinese major cities in order to set up communist government in China, following the orthodox Marxism-Leninism revolution line. is soviet revolutionary experience, however, failed to be accomplished in the Chinese scene. China had neither Marxism revolutionary precondition that communism was supposed to happen after the height of capital $\mathrm{sm}$, nor Russian experience (a developing capitalist society). It was a semifeudal, semi-colonial society. Jiang still attempted to

13 Strong., p. 27.

14 Ibid., p. 26.

is Ibid., pp. 30-31. 
thoroughly destroy CCP. A good example: is the Canton commune Uprising in 1927 which was ordered from Moscow caused CCP more seriously destroyed by Jiang's force. ${ }^{16}$

It was rao zedong who argued that a victory of Chinese communist revolutior should be achieved only through chinese methods. He incisively analyzed Chinese class structures, and pointed out that the peasantry, which was the major population in china and the lowest-level class, would play an active role in overthrowing Jiang's regime. Mao created a revolutionary tactic -- the Guerrilla War. These theories greatly distinguished from those of classic Leninism in which revolution was accomplished by a trained, organized and highly disciplined communist party, acting in the name of the working class. 17

Different ideological approaches toward communism road between the orthodox Marxism-Leninism 1 ine and the heretical Maoism line lay the first fundamental sino-Soviet split." Mao's ideology had never been acknowledged by the sovicts. ${ }^{19}$ stalin regarded Mao, a leader not being formally trained by Moscow, merely as an "agrarian reformer."20 Thus, even after

36 Ibid., p. 30 .

17 Roy C. Macridis. Contemporary Political Ideologies: Movements and Regimes. Glenview: Scott, Foresman and Company, 1989, p. 174.

18 strong., p. 30 .

19 Zagoria., The Sino-Soviet Conflict 1956-1961. p. 15 .

20 strong., p. 37 . 
Japan's surrender and CCP force became increasingly strong, stalin's political and military support continued to go to Iiang's government unil the GMD fled to the Taiwan Island. Stilin's unfavourable approach toward Mao caused Mao's antisoviet antipathy.

Through intense power struggle with orthodox Marxist leaders, the historical "Long March" to shake off Jiang's "extermination campaigns", and the waz against Japan (the third CCP-GMD alliance), Mao's CCP finally came to power in 1949. It was not until the CCP finally defeated Jiang's force that Moscow recognized Communist China." stalin did not anticipate Mao's success without any help from Moscow. Mao's victory not only proved stalin's misguiding of orthodox Marxism-Leninism line in China, but also broke down Stalin's thesis of "socialism in one country." There was no dolibt that by developing Marxism-Leninism, Mao and his cormunist party regarded themselves as one of prophets of communism rather than a disciple of communism. ${ }^{n}$ As early as 1946 in a foreign interview, Liu Shaogi, a major creator of Maoism, stated:

Mao zedong's great accomplishment has been to change Marxism from a European to an Asiatic form. Marx and Lenin were Europeans, they wrote in European languages about European histories and problems, seldcm discussing Asia or China... (Mao) uses Marxist-Leninist principles to explain Chinese history and the practical problems of China. He is the first that has succeeded in doing so... He has created a

21 Ibid.

22 zagoria., The sino-Soviet Conflict 1956-1961. p. 1 . 
Chinese or Asiatic form of Marxism. ${ }^{23}$

Between 1949 and 1951 Chinese regime intensively declared that Mao's theories on revolution would be a model for other underdeveloped countries to follow. 24

The Bolshevik October Revolution of 1917 created the USSR as the first world proletarian country and the guiding revolutionary leadership in the communism movement. Nevertheless, Communist China, as George Kennan stated, had regarded itself at least "an ally but not a satellite" to the Soviet Union. ${ }^{25}$ They not only developed Marxism-Leninism on their own, but also enjoyed chinese civilized culture and vast territory.

During stalin's leadership, China was unable to challenge to soviet supremacy in the communist movement primarily for several reasons. On one hand, China needed an alliance with the soviet Union. In order to build a new industrialized China and to consolidate CCP authority, china badly needed foreign economic, scientific and technical aids, and a military ally to protect China from American threat and attack from Jiang's regime in Taiwan supported by the United states. The Soviet Union was the only country that china could turn

Ibid., p. 14

in Ibid., p. 15 .

25 Ibid., p. 12 . 
to. ${ }^{26}$ In his first visit to Moscow in December 1949, Mao tasted Stalin's cold treatment. Stalin was very unwilling to meet. with him. ${ }^{n}$ After more than two months bargaining, a "Treaty of Friendship, Alliance, and Mutual Assistance" was signed in Moscow on February 14, 1950. China received Soviet technical assistance, and would send its students and trainees to the Soviet Union. Moreover, China gained a long term economic credit from Moscow (with US\$ 300 million in first five years). ${ }^{28}$ Despite the fact that this treaty was "full of unequal terms conductive to soviet exploitation of china" (a joint stock companies was set up in china to exploit Chinese raw resources), Mao's anti-stalin's stance was tightly concealed by significant contribution of the Soviet aid into the construction of chinese economy during the period of China's First Five-Year Plan (1953-57). ${ }^{29}$ Furthermore, motivated by its encouraging revolutionary enthusiasm and preventing the United states from extending the war to Chinese continent, China took part in the Korean War. The war intensified chinese economic and political isolation from the

26 Jacobsen., Sino-Soviet Relations Since Mao: The Chairman's Leaacy. New York: Praeger, 1981, p. 51.

$n$ c G. Jacobsen. "Sino-Soviet Normalization: The Forgotten story". (Paper for World Soviet studies Congress, Harrogate, England, 1990.) F. 1.

$2 a$ Jacobsen., sirio-Soviet Relations Since Mao. p. 50.

29 Ibid., and Walter c. clements. "Soviet Foreign Policy since 1917: Achievements and Failures," Survey, (London), Vol. 30, No. 4, June 1989, p. 97. 
West. Consequently, It st.engthened China's dependence on the Soviet Union, despite the CCP's successful competition with the United Nation forces dominated by Americans. ${ }^{30}$ Indeed, Chinese economic and military dependence on the soviet union forced Chinese regime to be very cautious and modest about their challenge to stalin's position in the communist movement. The year of 1951 witnessed disappearance of Chinese propaganda on Mao's revolutionary theory to underdeveloped areas. 31

On the other hand, the influence of soviet foreign policy during the stalin era was greatly limited. The soviet's tremendous cost in the second world war pushed stalin to be more concerned about soviet territory and the highly valuable extension of soviet frontiers. Though, at the same time, stalin tried to spread soviet power and hegemony in the world arena, he was not very interested in areas which he had difficulty reaching. This feature was proved by the fact that stalin intensively propped up communist regimes in Eastern European countries, and he held an inflexible attitude toward neutral countries. ${ }^{32}$ Furthermore, to prevent another Tito's emergence and challenge to soviet position in the communism movement, stalin tried to avoid another open confrontation

30 John Gittings. Survey of the sino-Soviet Dispute: A Commentary and Extracts from the Recent Polemics 1963-1967. London: Oxford University Press, 1968. p. 19.

31 zagoria., The sino-Soviet Conflict 1956-1961. p. 15.

32 Ibid., p. 19 . 
with a major communist leader which was able to contest with him, such as Mao."3

Thus, during Stalin's era, the sino-soviet dispute was hidden by the both sides. The death of stalin left Mao feeling himself to be the only major spokesman for the international comunism movement.

\section{Khrushchev's roreign Pollcy and Rasponse From China:}

The death of stalin in March 1953 caused a great change in the Soviet foreign policy. On August 8, 1953, the new Soviet Premier Georgi Malenkov announced the new stance of policy -- "peaceful coexistence." ${ }^{34}$ It was written into Khrushchev's report of Party Congress in 1956, as a new fundamental principle of the Soviet foreign policy. Khrushchev repudiated Marxist-Leninist concept that wars were inevitable as long as imperialism existed. 3

The introduction of this new posture reflected new Soviet leaders' re-evaluation of the soviet domestic and international situations that faced them. Politically, the Soviet leadership recognized that the consequence of stalin's policy of self-imposed isolation (Stalinist xenophobia) "had

33 Peter Zwick. Soviet Foreign Relations: Process and Policy. New Jersey: Prentice Hall, 1990. p. 28.

3 Adam Ulam. Expansion and Coexistence: The History of Soviet Foreign Policy 1917-1967. New York: Fredirck A. Prager, 1968. p. 547.

3s Khrushchev's Report to the 20th Congress, 1956, in Livermore, Gordon (ed.) soviet Foreign Policy Today: Report and commentaries from the soviet Press. 3rd edn. 1989. p. 6. 
created an alr of tension, which apart fron being a source of danger to Russia, was largely unnecessary." Union had become not only one of the two world superpowers, but also the recognized leader of the world communism movement. Economically, the Soviet Union had reached a stage of Industrial development, and appeared to be in a position to achieve substantial improvement in its backward agricultural and living standards. Stalin's policy of forced industrialization and the pursuit of military power had enable the Soviet Union to achieve great power status. By 1957, the Soviet Union had developed the atomic bomb, and subsequently also the hydrogen bomb. 37

Despite the fact that the Soviet leadership was feeling confidence and security that new-found military forces gave them, they clearly acknowledged that the USSR did not have military superiority over the United states."3 Thus, the objectives of their new policy aimed to raise the prestige of the Soviet Union both at home and abroad; to increase trade with the West in order to gain the needed advanced technology and to improve soviet living standards."

Khrushchev's new foreign policy created an overwhelming

36 Ulam., p. 543 .

37 Ibid., p. 545.

38 Zwick., p 38 .

39 Ibld. and Leigh Sarty. "Canadian-Soviet Relaticns, 1955-1989: Three Encounters," (occaslonal paper), p. 6 . 
opposition from China, as Beifing found itself at a disadvantage when compared to Moscow's position. China was relatively isolated in the world political environment -- its establishment won recognition from only a handful of countries; many major countries, including the United states still refused to recognize $1 t .^{40}$ More seriously, China was in direct confrontation with the United state, which not only supported Jiang's elite, but also its occupation of the Taiwan Island." The Jiang's regime in Taiwan was seen as a constant threat to the solidarity of Mao's government.

Economically, China was in an early stage of development. Its industrialization was at a very low level, and its primitive and backward agriculture barely managed to keep abreast of the population growth. Militarily, unlike the Soviet Union, China had neither atomic nor hydrogen weapons, with which to achieve political goals. These features showed that China must rely on the Soviet Union's aid, especially concerning China's economic construction and recapture of Taiwan. Unlike the Soviets, the chinese did not come to realize that Moscow had not achieved military superiority over Washington. They believed the soviet strengthened military force had led to a great change in the balance of power of East-West relations. They expected the Soviets to use their

$\omega$ R. Lowenthal. "Factors of Unity and Factors of Conflict," Innals of the American Academy of Political and social science, september 1963, p. 110.

4 Ibid. 
milltary force to destroy the Americans once and for all.". The differences between the soviet Union and China concerning their levels of economic development, military security and political environment generated divergent outlooks on the world. Furthermore, their own outlook was enlarged by the dissimilar revolutionary experiences between these two parties. The Soviet Bolsheviks came to power almost overnight. In contrast, Chinese communists experienced hard internal wars for more than two decades. As a result, different outlooks between both sides involved several issues, concerning ideological assessments (such as nature of epoch, war and peace, peaceful transition to socialism), and strategy and tactic of foreign policy related divergent ideological aspects (such as national liberation struggle, soviet rapprochement with the United States)."s

According to Moscow, "the present epoch is distinguished by the transition from capitalism to socialism, and by the extension and consolidation of a world socialist system." China rejected this perception, claiming that it was still the epoch of imperialism, wars and revolutions. Chinese leaders thought that this epoch was characterized by the aggressive nature of imperialism. But, the soviet elite juxtaposed:

Imperialism is still aggressive by nature, but the position of imperialism in the world, and especially its

42 Zwick., p. 39.

43 For a good summary, see K. Z. Brzezinski, The soyift Bloc: Unity ind conflict. pp. 397-406. 
ability to take aggressive action have radically changed." several Iseues During the conflict:

The Sino-Soviet dispute during the Khrushchev era, as mentioned previously, touched on divergent outlooks from both sides. The outlook was seen to be tightly joined with their own national interests. Different national interests had involved many issues, such as: whether the Soviet Union should assist China with nuclear weapons; what risks Moscow would meet, if Beijing would bombard Taiwan; and what attitude of Moscow should have toward the Indo-China dispute. ${ }^{\text {is }}$

In terms of the international communist movement, Khrushchev hoped to create a new self-regulating system to replace stalin's highly informal supranational autocracy. He was willing to tolerate domestic diversity in communist countries, but they should all be bound by a common ideology." However, this policy (including destalinization) soon caused precipitated uprisings in Poland and Hungary in 1956; it also greatly disappointed the Chinese communists. East European uprisings made China for the first time participate affairs of the Soviet Eastern Bloc."

The Moscow conference in November 1957 issued a 56.

4 zagoria., The sino-Soviet Conflict 1956-1961. pp. 55-

45 See Gelman., "The conflict: A Survey," pp. 3-15.

4 Brzezinski., The soviet Bloc: Unity and Conflict. p. 397.

on strong., p. 41. 
declaration of unity by all communist parties, stressing the importance of unity." Mao attended this conference himself. He supported soviet leadership within the international communist movement, claiming "every snake must have a head," and this head was the soviet Union." The implication of Mao's declaration was by no means Mao's concession of his challenge to Khrushchev's position in communist movement. Mao regarded himself as the greatest living communist theoretician and revolutionist in communist movement. The Chinese regime needed to maintain the unity of communist world to antagonize the West, especially the United states. Inside this unity, what China also needed was the military unity. It was clear later that Mao's claim in the 1957 Moscow Conference was designed to receive soviet military support to strengthen the Chinese military force. Within less than month after the conference, a sino-Soviet agreement, concerning new technology for Chinese national defense was signed, under which China would receive a sample of an atomic weapon from the soviet Union. ${ }^{50}$ China needed the Soviet support to sustain pressure against Taiwan. However, the Soviet Union remained acutely sensitive to the risk of nuclear war, and consequently

4 K. 2. Brzezinski. "Pattern and Limits of the sinoSoviet Dispute," Problems of Communism. Vol. IX, SeptemberOctober 1960 , p. 2 . 103.

4 clements.. "Soviet Foreign Policy since 1917", p.

so Gelman., "The Conflict: A survey", p. 6. 
discouraged any local offensives." Khrushchev took an unscheduled visit to Beifing in July 1958, attempting to change Mao's mind of liberation of Taiwan, but he failed. 52 It was very likely that Khrushchev feared the possibility of China's bombing Taiwan and consequently nuclear conflict with the United States. In 1959, the Soviet Union denied nuclear weapons to China, and withdrew its military assistance. It was sald that Khrushchev suggested to Mao accepting of two-China solution on the Taiwan issue."3 Beijing regarded Washington as the principle obstacle to Chinese influence in Asia, and considered pressure against the United States in the world as essential to its national interests. Khrushchev's visit to Washington in 1959, the Soviet initiatives toward detente with the United States and negotiations with the US, as viewed by Mao, were indirectly at China's expense. Around 1958 China launched its own independent nuclear program."

Different revolutionary interests also separated the Soviet Union and china, adding to their conflict, and undermining their relationship, though both were committed to communism and believed in fermenting revolution and the ultimate victory of communism in the world. Their differences

si Lowentha1., p. 111.

52 Gittings., p. 89.

53 Gelman., "The conflict: A survey", p. 8 .

It zagorla., The sino-soviet conflict 1956-1961. p. 18 and p. 22 . 
concerned pricrity, sectionalism and the timing of revolution. The Soviet's primary target was to guide revolutions in Europe, and especially in the more advanced western countries." Khrushchev intended to change the Soviet Union from an isolated regional power during Stalin's era to a world-wide superpower. ${ }^{\text {S6 }}$ His strategy toward the Third World (Khrushchev called "a zone of peace") was to use the soviet economic and military aid to countries, such as India, Egypt, Afghanistan, in an attempt to break down the western monopoly of influence in these areas. ${ }^{57}$ The strategy brought the Soviet's into confrontation with china, because the chinese aimed at guiding revolution in underdeveloped areas, primarily in the Third World.

By 1957 Soviet economic aid to China had been cut back sharply in favour of more aid to the East European Bloc and neutral countries. But, more inportantly, it was because of the confrontation between the two sides. Being dissatisfied with the Soviet model and the level of Soviet aid, Mao launched policies of economic self-reliance -- "the Great Leap Forward" in 1958, which aimed not only at the rapid communization of China, but also at bypassing the Soviet Union

ss Ibid., p. 19.

s6 Zwick., p. 44.

37 Ibid., p. 40. 
on the way to communism." They attempted to create a unique model for underdeveloped countries to follow, thus to challenge soviet leadership in the communist movements. ${ }^{59}$ The soviets criticized chinese actions, saying China's lack of material incentives characterized the commune system, and suggested that it was much more realistic to expect the soviet Union to attain the levels of production required for full communism rather than Communist China. ${ }^{0}$ On July 1959 at Poznan of Poland, Khrushchev (without referring to China by name) commented that those who had set up communes "had a poor understanding of what communism is and how it is to be built. "61

The sino-soviet alliance reflected the comnonality of communist ideology, and therefore conflict with the West, that resulted from the coming to power of Communist china. ${ }^{62}$ Both countries were conscious that their unity was a decisive factor of strength vis-a-vis the non-communist world, which both interpreted as hostile. ${ }^{63}$ In a speech of the 21 th CPSU

34 Franz Michael "The struggle for Power," Problems of Communism, May-June 1967, p. 12. and Gittings., The sinoSoviet Dispute. Pp. 22-23.

s) Gittings., p. 23.

"Gelman., "The Conflict: A Survey", p. 7.

Ibid., p. 8 .

62 Lowentha 1 ., p. 108.

B Brzezinski., "Pattern and Limits of the sino-Soviet Dispute*, p. 2 . 
Congress, A. I. Mikoyan, Deputy Premier stated:

soviet-chinese friendship rests on the unshakable foundation of Marxist-Leninist ideology, on the common goals of communism, on the fraternal and mutual support of the peoples of our countries, on joint struggies against imperialism and for peace and socialism.... We should cherish this friendship as the apple of our eye.

This common guideline, indeed, once provided possibility for easing the dispute. For instance, the year of 1962 saw the celebration of the sino-Soviet alliance's tenth anniversary on the both sides in February and signature of a new bilateral trade agreement in April."s In meetings with the departing Chinese Ambassador Liu $x i a o$ on October 13 and 14, 1962, Khrushchev asked both sides to forget the past and "start our relations with a new clear page." Khrushchev also expressed coupiete sympathy for Beijing's stand on the borier conflict with India, implicitly endorsing the Chinese intention to use force in that conflict. ${ }^{\text {to }}$ Nevertheless, with Khrushchev's further rapprochement with American President Kennedy, signing test ban treaties with the united states in 1963, the bilateral relations was completely broken down. ${ }^{6}$

Relations During the Brezhnev Era:

On October 141964 , Khrushchev was removed from his position of leadership. Leonid Brezhnev replaced him as First
attings., p. 7
65 Ibid., p. 169.
6o Gelman., "The Conflict: A Survey", p. 13.
67 Gittings.. p. 185. 
Secretary of the CPSU and Alexel Kosygin as prime Minister. The dismissal of Khrushchev brought temporarily improved relations between Moscow and Beijing. It could be seen from the greeting messages sent by Mao and his colleges to Brezhnev and Kosygin, and the participation of a chinese delegation led by Primer zhou Enlai on Moscow's anniversary celebration of Bolshevik Revolution in November 1964.6

However, it was soon clear that the new Soviet leadership was not prepared to abandon Khrushchev's foreign policy, but rather was determined to pursue it. On November 6 , in a public speech, Brezhnev stated that Moscow would continue its foreign policy laid down by Khrushchev. ${ }^{\circ 9}$ The main features of this policy were consistent, including pursuing the unity of the world communist camp, support for national movenents, cooperation with the non-aligned countries and peaceful coexistence. Then, attacks from Beijing and Moscow on each other which had been restrained just for few weeks because of the downfall of Khrushchev were soon resumed. On November 20 , China's authoritative magazine Red flag made a violent denunciation of Khrushchev, and referred to the Soviet's new policy as "Khrushchevism without Khrushchev". 70

Nevertheless, the most important feature of sino-soviet

68 Peter Jones and Sian Kevill (Compi lєd). China and tice Soviet Union 1949-1984. (Keesing's International

Studies) London: Longman, 1985. p. 60.

69 Ibid.

70 Ibid., pp. 60-61. 
relations in the second half of the $1960 \mathrm{~s}$ was not two countries' public confrontation. It was the emergence of a tense, dangerous military confrontation. In the past, the sino-Soviet split was essentially ideological and political, now it developed into a direct military conflict.

Both sides had seen a growing threat to own security, and began to strengthen their border defense to prepare for a possible military conflict. starting in 1965, Hoscow initiated a military build-up along the sino-soviet boundary. Perhaps, the soviet military build-up was motivated by soviet regime's considerations of China's explosion of its first nuclear device in 1964, China's claims on soviet territory and the unpredictability of Beijing leaders during "the cultural Revolution". Moreover, the soviets might expect to use military pressure to force the chinese to compromise."

The Soviet's large scale military build-up along the sino-Soviet border, combined with increasing border incidents posed a growing threat to China. Moreover, the Soviet invasion of Czechoslovakia in 1968 and the Brezhnev doctrine of "limited sovereignty" (under which the soviet union had the right to intervene in a country where socialism was being threatened) posed a threat to China. Beijing feared that this action was a prelude to similar soviet intervention into

7 A. Doak Barnett. China and the Major Powers in East Asia. Washington, D.C.: The Brookings Institution, 1977. p. 49. 
China.n The chinese reaction to the soviet invasion of Crechoslovakia was hostile. In his report to the Ninth Congress of the CCP in April 1969, Lin Plao strongly condemned the Brezhnev doctrine and compared "Soviet social imperialism" to Hitlerism and Japanese imperialism."

The CCP's Ninth Congress in April 1969 formulated China's overall foreign policy and its basic policy toward the soviet Union as well.74 Under the new guideline, China was trying to form the broadest possible united front to further the worldwide revolutionary struggle, by strengthening unity :ith oppressed people and nations of the world, and with all. countries subjected to imperialist aggression. The soviet Union was referred as a social imperialist country, placed on the equal footing as the imperialism of the United States. Some western scholars had argued that since 1969 China

$n$ Kenneth w. Rea. "Peking and the Brezhnev Doctrine", Asian Affairs: An American Review. Vol. 3, No. 1, September/October 1975, p. 22.

$n$ Piao Lin. "Report to the Nintr: National Congress of the Communist Party of China", Peking Review. (later renamed as Beijing Review) Vol. 12, No. 18, April 30, 1969, p. 30.

74 Pias Lin. "Report to the Ninth National Congress of the Communist Party of China", pp. 16-35. Lin stated four major contradictions in the world: the contradictions between the oppressed nations and imperialism (social imperialism), between proletariat and bourgeoisie, between imperialist (social imperialist) countries and imperialist countries, between socialist countries and imperialism (social imperialist). (see p. 31.) 
had put Moscow above Washington as its Number One Enemy.75 This argument was supported by the intense military deployment along sino-Soviet border by both China, and the Soviet Union and the Sino-American rapprochement symbolized by the Nixon's visit to Beijing in 1972.

The Border Issues and the 1969 Border Clashes:

The deterioration of sino-soviet relations inspired the Chinese leaders to raise the boundary issue. It was on March 8, 1963 that China, for the first time, publicly raised the territorial claims against the Soviet Union. They asserted that the treaties (of 1858, 1860, 1881) signed between Tsarist Russia and Chinese Manchu Erapire were "unequal", as these treaties had been imposed by force, and therefore, theoretically invalid." At the same time, Beijing tried to reexamine the entire boundary question and to sign a new treaty to replace the old one, tnough china was prepared to take the old treaties as a basis for the border settlement. The Soviet Union rejected China's claiming of the existing of "unequal" border treaties and refused to have comprehensive boundary negotiations. They were only prepared to make minor adjustment to the frontier with china.

The boundary negotiations began in Beijing on February

75 Joseph Y.S. Cheng. "China's Foreign Policy: Continuity and Change", Asian Quarterly. No. 4, 1976, p. 308 .

76 Harold C. Hinton. The Sino-soviet confrontation: Implications for the Future. New York: Crane, Russak Company, Ine. 1976 . p. 11. 
25, 1964, but no progress was achieved. Again, a Chinese delegation proposed to readjust individual places on the border, by using the old "unequal" treaties as a basis for a boundary settlement. The soviet side rejected these proposals. They proposed only for the "clarification" of certain section of the border. $n$

since the raising of the border issue by the chinese side, a number of incidents provided evidences that tensions on the frontier had greatly increased. For instance, in september 1963, China alleged that the soviets carried out a large-scale subversive activity in xinjiang Province and incited tens of thousands of Chinese citizens across Xinjiang to take refuge in the Soviet Union. ${ }^{78}$

The border armed clashes between Chinese and soviet forces along both Xinjiang and Ussuri-Amur sectors continued. On March 2 1969, a serious clash took place on the Ussuri River, over a disputed island (called Damanskii by the Russians and zhenbao by the Chinese), which drew world attention. Both governments sent strong protest notes to the other on the same day. As both sides demanded the punishment of the responsible persons, Moscow declared that "reckless and provocative actions by the chinese authorities would be met on our (Soviet) side by a rebuff", while Beijing declared that if

$n$ Jones., and Kevill., (compiled) China and the soviet Union 1949-1984. p. 90 .

7 Ibid. 
Moscow continued to provoke armed conflicts, it would receive "resolute counter-blows"."

Just few days later, on March 15, a large scale fighting again occurred in the same area. Each side blamed the other for opening fire first and for having violated the other's territory. The Soviet scholars claimed that the armed clashed on the Ussuri River was planned in advance and carefully prepared by the $\mathrm{Ch}^{\text {i }}$ ese side. ${ }^{20}$ It was widely reported that the Chinese initiated the March 2 incident in response to a long period of harassment along the border by the soviets, and that the Soviets were responsible for the following initial attack, as they intended to teach the Chinese a lesson and to provoke a war of nerves with them."

The war did not break out partly due to the soviet reaction. On his way home via Beijing from the funeral of Ho Chi Minh, President of the Republic of North Vietnam, the Soviet Premier Kosygin met with his counterpart zhou Enlai in Beijing Airport in september 1969. The meeting halted the escalation of tension that had threatened to erupt into war throughout 1969, and resulted in resumption of border talks in October 1969.

7 Ibid., p. 93.

w O. B. Borisov. and B. T. Koloskov. Soviet-Chinese Relations, 1945-1970. Bloomington \& London: Indiana University Press, 1975. p. 323.

1 Sung An Tai. The sino-soviet Territorial Dispute. Philadephia: The Westminster Press, 1973. p. 94. 
Perhaps, China did not want a full-scale war either. The internal political upheavals caused by "the Culture Revolution" greatly isolated china from broad contacts with foreign countries. Having only Albania and North Vietnam as its close friends in the international arena, the Chinese regime clearly realized that China could hardly hope to contain the Soviet Union." The crisis of China's internal security, caused by armed clashes between rival political factions, reduced China's overall milltary capability. As a result, China's ability to reinforce war preparations in the event of an external crisis seemed to be severely weakened." Thus, China was fully aware of its military weakness vis-a-vis the Soviet Union. The balance of power was not in its favour, and Beljing strategy in its relations with Moscow was to avoid any direct confrontation. Thus, Beifing agreed to have talks with Moscow.

sino-Soviet border negotiations begun on October 201950 and continued with many ups and downs until July 1973. T'ze negotiations did not produce any significant results, but they helped keeping the cold war between the two countries from turning into a hot war. It was reported that during the border

1 William V. Wallace. "sino-Soviet Relations: An Interpretation", Soviet studies. Vol. XXXXV, No. 4, October 1983 , p. 467.

"3elvin Gurtov and Byong-Moo Hwang. China Under Threat: The Politics of strategy and Diplonacy. Baltimore and London: The Johns Hopkins University Press, 1980. p. 187. 
talks, the soviet delegation put forward a proposal to sign a non-aggression treaty, under which both sides would not attack or threaten each other with any type of weapons. However, China rejected this proposal, stating it was unnecessary since the treaty of alliance of 1950 was still in force." Again, in October 1974, Moscow repeated its offer of a non-aggression pact to Beifing, but it met with rejection from china again. During 1969 to 1982, Sino-Soviet border incidents continued to take place. Several times China accused the Soviet Union of encroaching on Chinese territory in xinjlang Province. For instance, China alleged that from January 1973 to March 1974, the Soviet aircrafts had intruded into Xinjlang 61 times and some of them were engaged in espionage."s within this decade, border negotiation had been a main content of the bilateral relations. The corder issue was a very tough one to address. The result of the border negotiation in February 1975 reached an agreement that border issues should be examined item by item, rather than in its entirety." The Joint sinoSoviet Commission for Navigation on the Far Eastern Rivers met in Heine (a city of Chinese Helongjiang Province) during July 1977 to October 1977. They reached a limited agreement, under which Chinese ships would use the eastern watercourse on the

Hones., and Kevill., (compiled) China and the Soviet Union 1949-1984. p. 144 .

is Ibid., p. 147.

4 Ibid., p. 148. 
Amur River, when the Kazakevich Channel was not deep enough for navigation."

During the period of 1969-1979, Sino-Soviet relations changed very little, and very few politically important meeting at high level took place. This period was characterized by an extraordinary stalemate in direct dealing, continued military confrontation, diplomatic encirclement and counterencirclement, and ideological estrangement.

According to the reference book of Wilitary Balance for 1973-1974, published by London's Institute of Strategic studies, after border clashes in 1969, the military forces of both sides stationed along the common border were dramatically increased." Prior to 1968, 15 divisions of Soviet troops were deployed in the Far East, which accounted for 11 percent of its total army divisions. From 1969 to 1973, the number of army forces were increased rapidly: 21 divisions in 1969, 30 divisions in 1970, 33 divisions in 1971. By 1973 there were 45 divisions deployed in this area. This amount was 28 percent of the Soviet 164 army divisions. On the Chinese side, 48 divisions were stationed along the sino-soviet and sinoMongolia borders, which constituted about 40 percent of China's total of 120 divisions. By 1973 the deployed ground

7 Ibid., p. 150. The Joint Sino-soviet Commission for Navigation on the Far Eastern River was established in 1951 and was proposed to meet annually. But due to border tensions, they did not meet during 1967-1968 and 1974-1976.

" Ying-hsien Pin. "Peiping-Moscow Relations: An Evolving Trend", Issues and studies. Vol. 11, No. 3, 1975, p. 61. 
forces ralses to 70 divisions (including 1.5 million of Chinese military army, three times as many as the soviet forces)."

Following the Soviet Invasion of Czechoslovakia and the Sino-Soviet border clashes in 1969, Chinese leaders led by Zhou Erilai sought to open contacts with the United States in an effort to play the American card against the perceived Soviet threat. This led to the beginning of rapprochement of sino-American relations, first signified by us President Nixon's visit to China in February 1972.

Mao Zedong personally played an important role in the deterioration of Sino-Soviet relations. However, the passing of Mao in 1976 did not inspire any significant changes in sino-Soviet relations. It was really difficult for the both sides to ease the deep-seated antagonisms.

In September 1976, Moscow suspended its anti-Chinese polemics and sent China sondolences for Mao's death, hoping for improving relations with China. However, Beijing informally rejected Moscow's condolences, observing that there were no official CCP-CPSU ties. A similar exchange happened, when Hua Guofeng was elected as Chairman of the central Committee of CCP in late October $1976.0^{\circ 0}$

\section{Ibid.}

"Harold C. Hinton "Moscow and Peking since Mao". current History, Vol. 75, No. 440, October 1978, p. 121 . 
The Initial poriod of rormalisation of 8ino-8oviet Relationas

The first stage of talks on normalization of sino-Soviet relations can be dated to 1979. In April 1979 the Chinese government passed a note to Koscow that China had decided not to extend the "Sino-Soviet Treaty of Friendship Alliance and Mutual Assistance", which would be nullifled on April 11, 1980. However surprisingly, at the same time, China proposed that both sides could hold negotiations to solve outstanding issues between the two countries. The proposal was accented by the Soviet government."

From September 1979 to November 30 of that year, SinoSoviet vice-ministerial talks were held in Moscow. However, the first round of the talks ended without any results. Big gaps remained between China and the soviet Union. China insisted on a comprehensive content in negotiation, involving not only issues of bilateral relations but also Soviet foreign policy, while the Soviet Union wanted the negotiation to be limited in bilateral relations." Yugoslav sources reported that during the talks, three preliminary conditions for normalization of bilateral relations were put forward by the Chinese: 1) the decrease of the Soviet troops along the sinoSoviet borier from the present 54 divisions to the 12

" Segal, Gerald. Sino-soviet Relations after Mao. London: the International Institute for strategic studies, 1985. (Adelphi Papers, No. 202), p. 8.

2 Ying-hsien Pin. "Peiping-Moscow Relations in the Post-Treaty Era: The Search for a New Framework", Issues and studies. Vol. XVII, No. 8, August 1981, p. 57. 
divisions prevailing in the Khrushchev era; 2) withdrawal of all Soviet forces from Outer Mongolla; and 3) cessation of the Soviet support for the vietnamese occupation of Cambodia." The soviet response to these demands was said to offer the Chinese a partial withdrawal in exchange for signing a sinoSoviet nonaggression treaty.4

The only outcome from this round of negotiations was that both sides agreed to hold a second round of the talks in late February or early March 1980. But the proposed talks were suspended by the Soviet invasion of Afghanistan at the end of 1979. On January 19 1980, a spokesman from Chinese Foreign Ministry stated that it was inappropriate to have further negotiations with Moscow, since the soviet invasion of Afghanistan threatened "world peace and China's security"."s Then, the issue of withdrawal of soviet troops from Afghanistan was added to the normalized sino-soviet relations.

The rapprochement between China and the United states provided a new challenge to the Soviet Union. Previously, Moscow could deal with these two adversaries separately, now it had to face a situation, in which Beijing and Washington could coordinate against Moscow.

93 Ibid. and Steven I. Levine. "The Unending Sino-3oviet Conflict", Current History, Vol. 79, No. 459, October 1980, p. 71 .

* Levine. "The Unending sino-Soviet Conflict", p. 71.

95 Jones., and Kevill., (compiled). China and the soviet Union 1949-1984. p. 140 . 
Several times before his death, Brezhnev signalled his wllingness to hold serious discussions with China. At the 26th Party Congress in 1981, Brezhnev had already acknowledged that changes of inte;nal policies were occurring in china and that, to some extent, China's leadership was succeeding in overcoming Mao's legacy. $*$ The year of 1982 especially saw Brezhnev's repeated interest in improving relations with China. In his Tashkent speech on March 24, 1982, Brezhnev accepted the existence of a special socialism in China and expressed soviet readiness to enter into a constructive dialogue on the border dispute and normalization of bilateral relations." The Tashkent speech was widely reported as a significant development. The article of I. Aleksandrov (a pseudonym representing the top Soviet leadership) on May 20, 1982 in Pravda asserted that "we are deeply convinced that there is a real possibility for improving soviet-chinese relations". Again, in his speech in Baku in september 1982 , Brezhnev mentioned that one of important soviet goals in Asia

* I. I. Brezhnev. "The Report of the CPSU central Committee to the 26th Congress of the Communist Party of the Soviet Union and the Party's Immediate Tasks in the Fields of Domestic and Foreign Policy", Pravda and Izvestila, February 24, 1981, pp. 2-9. Text is translated in CDSP. Vol. 33. No. 8, March 25, 1981, p. 7.

$n$ "Comrade L. I. Brezhnev's stay in Uzbekistan", Pravda, March 23, 1982, p. 1. Text is translated in CDSP. Vol. 34, No. 12, April 21, 1982, p. 6.

"I. Aleksandrov. "On Soviet-Chinese Relations", Pravda, May 20, 1982, pp. 4-5. Text is translated in CDSP. Vol. 34, No. 21, June, 23, 1982, p. 23. 
was to improve relations with China."

It was obvious that Moscow expected to take advantage of new tensions between China and the United States, created by American pro-Taiwan pollcy and export restriction of Chinese textiles to the United States under Reagan's leadershif. ${ }^{100}$

Indeed from 1981 to 1982 , some steps indicated a better but limited rapprochement between China and the Soviet Union. China purchased about half a million books from the Soviet Union, and it began to use soviet railways to transport its goods to Europe. Athletes from the both sides took part in sports competitions held in each others' country. Trade and visit exchanges by economic scholars and enterprisers from the two sides gradually increased. ${ }^{101}$

Relations During the Periods of Andropov and Cherenenko:

The death of Brezhnev and the ensuing changes in the Soviet leadership did not alter the trends in sino-Soviet relations, but it provided the opportunity for the highest official contact by two sides since 1969. Huang Hua, Chinese

9 Peggy I. Falkenheim. The soviet Union, China and Japan: Trilateral Relations in Flux. Toronto: York University, 1984. p. 6 .

100 Gibert Rozman. "Moscow's China-Watchers in the PostMao Era: The Response to a Changing China" China ouarterly, No. 94, June 1983, p. 221. In this paper, Rozman analyses in detail soviet divergent groups of scholars' and leaders' view on normalization of Sino-suviet relations. Also see, Chi Su. "Soviet China-Watchers' Influence on Soviet China Policy", Journal of Northeast Asian Studies. Vol. II, No. 4, December 1983, pp. 25-49. Era", Rozman.
p. 221 . 
Minister of Foreign affairs, attended Brezhnev's funeral in November 1982. Before leaving Moscow, Huang Hua praised Brezhnev's contribution to the improvement of sino-soviet rolations and stated that he was "optimistic" about future sino-Soviet negotiations. 112 Hua's meeting with Andropov and the Soviet Foreign Minister Gromyko was noted by the world press.

Under the Andropov administration, the soviet policy toward China was pursuing Brezhnev's policy: partial rapprochenent in relations with China without any concession on "third country" issues, i.e. Soviet relations with Afghanistan, Mongolia, and Vietnam. ${ }^{103}$ From 1979, the soviet Union had insisted that Moscow would not discuss these issues with China bilaterally, because these issues should be discussed directly between China and the concerned country.

In November 22, 1982, the new Soviet leader Andropov stated the soviet desire to betcer relations with all socialist nations, including "our great neighbour ... the People's Republic of China". The comment from chinese government on his statement was that Beijing hoped the new Soviet leader to "make a new effort in eliminating the

in Beljing Xinhuan in English, November 18,1982 , in IBIS-SOV-82-22,3, November $18,1982, \mathrm{p}$. B1. It is not clear that the repl cement of Huang Hua as foreign minister shortly thereafter was connected with this overstatement.

103 William E. Griffith. "Sino-Soviet Rapprochement?" Problems of Communism, Vol. XXXII, No. 2, March-April 1983, p. 24 . 
obstacles hindering normalization of relations".104

However, no effort was seen from the Soviet side. Attacks in the Soviet and Chinese media on each other's policies still continued. On December 27, the Chinese People's Daily accused Soviet aggression against Afghanistan of "a major step in the Soviet global strategy for world domination". The Soviet New Times questioned chinese claims to the Soviet territory, annexed by Tsarist Russia under "unequal treaties". It stated that a genuine desire from China for normalized relations was a Chinese renunciation of territorial claims. ${ }^{105}$

since November 1982, China and the Soviet Union had been holding talks aimed at normalizing their bilateral relations. The talks were held twice a year (in the spring and the fall) alternatively in Moscow and Beijing, with each round lasting for about two weeks. While making no progress on disputed political and military issues, these talks produced agreements and expanded cultural and economic relations between the two countries.

From March 1 to 15 1983, Leonid Ilyichev and Qian Qichen, Vice Foreign Ministers from both sides, held a second round of talks in Moscow. It was reported that the Soviet side propor d again to sign a non-aggression pact, but they refused to discussed issues involving Afghanistan and Kampuchea. The

104 Jones., and Kevill., (compiled) China and the Soviet Union 1949-1984. p. 179.

105 Ibid. 
Chinese delegation insisted on removing first "the three obstacles", otherwise the signing of such a pact would have little meaning. 106

Mikhail Kapitsa, the Soviet Deputy Foreign Minister, visited China during september 8 to 16,1983 , as the guest of his counterpart Qian Qichen. His talks with Qian and Wu Xuegian separately (the latter replaced Huang Hua as Foreign Minister) were described by Kapitsa as "businesslike". The result from this visit was the signing of an agreement on expanding exchanges of students and tourists, and increasing trade and low-level technological exchanges. The foreign press paid special attention to the warming signal of sino-soviet: relations. As during Kapitsa's visit, China was one of four countries, which abstained on september 12,1983 , on the draft UN Security Council resolution which deplored the destruction of a Souch Korean plane shot down by the Soviet Union after flying into soviet airspace. ${ }^{10}$

The third round of talks between cislegations led by Ilyichev and Qian started on October 6, 1983, in Beijing. However, there was not only no apparent progress made toward the "three obstacles", but this time the matter of deployment of Soviet ss-20 missiles along the sino-soviet border was included by the Chinese delegations in one of these "three obstacles" - the reduction of soviet forces along the sino-
lis Ijid., p. 180 .
107 Ibid., p. 181 . 
Soviet border. ${ }^{100}$

Only 15 months after succeeding Brezhnev, Yurl Andropov succumbed to a long illness. Konstantin Chernenko succeeded to his post. It seemed that Chernenko was less interested in improving relations with China than was Andropov. This could be seen from the comparison between the two leaders' treatments of the Chinese and vietnamese delegations. When Chinese Foreign Minister Huang Hua attended Brezhnev's funeral, he was met with his counterpart Andrei Gromyko. At the same time, Vietnam sent its Foreign Minister Nguyen Co Thach, however, he was only received by Leonid Ilichev, a Soviet Vice Foreign Minister. In contrary to this, at Andropov's funeral in February 1984, Beijing sent the vice Premier Wan Li to Moscow, the highest Chinese leader to Moscow since 1969. Chernenko chose to Ignore the Chinese gesture of goodwill, and Wan $1 i$ was greeted only by Geidar Aliyev, a Soviet Politburo member. Chernenko himself held the talks with the Vietnamese delegation led by Truong Chinh, Vietnam's state leader. ${ }^{109}$

Leonid Ilyichev and Qian Qichen met together in Moscow in the fourth round of talks (March 12-27, 1984). The talks went

108 Ibig.

109 Robert C. Horn. "Soviet Leadership Changes and sinoSoviet Relations", orbis, Vol. 30, No. 4, winter 1987, $p$. 689., and Chi Su. "Sino-soviet Relations of the 1980s: From Confrontation to conciliztion", in samuel s. Kim (ed.) China and the World: New Direction in Chinese Foreign Relations. (Second Edition) Boulder: Westview Press, 1989, pp. 111-112. 
through in a frank and calm atmosphere, but except for a joint statement on expanding trade, culture and sport contacts, the main issues had not been resolved. The meeting between Qian and Andrei Gromyko on March 23, 1984 touched on international issues. Both discussed the need for a positive dialogue between them, and Gromyko expressed his hope for a further improvement in relations."

Ronald Reagan paid a visit to China during April 26 to May 1, 1984. The visit, which was the first by a US president since the establishment of formal diplomatic relations in 1979, ended with the signing of four protocols (nuclear cooperation, an agreement to rssume cultural exchanges, a tax agreement preventing double taxation of chinese and US companies operating in the other country). The visit had brought a further improvement in sino-American relations. Moscow was seemed unhappy about Beijing's warm posture toward Washington. They criticized China's military cooperation with the United states, and complained about a recent Chinese antiSoviet statement. Then, the scheduled visit by soviet First Deputy Premier I. Arkhipov to Beijing was postponed."11

110 Jones., and Kevill., (compiled) China and the soviet Union 1949-1984. P. 184 .

III Alfred D. Low. The sino-Soviet Confrontation since Hao zedong: Dispute, Detente, or Conflict? New York, Boulder: Social Science Monographs, 1987, p. 65. The other reason for cancel of Arkhipov's visit was Kremlin's resentment against sino-American agreement on selling antitank and anti-aircraft to Beijing, resulted from visit to us by China's Defence Minister zhang Aiping in June 1984. 
On June 18 the new Sovlet leader Chernenko for the first time directly condemned China for its invasion of Vietnamese territory. China, in return, denounced soviet support for Vietnam and compared the soviet invasion of Afghanistan to "Nazi atrocities"."

Qian Qichen, as the official guest of M. Kapitsa, visited Moscow in July 1984. The meeting between Qian and Gromyko on July 2 was reported by Tass as part of "consultations on international issues", and the talks were described as "useful" by Qian later. The following contact between two Foreign Ministers, Andrei Gromyko and Wu Xuegian in New York on september 21-22, the highest formal contacts between two countries since 1969, promoted bilateral ties into a new positive period. On the occasion of the 35 th anniversary of the foundation of china, the soviet government sent a warm message to the Chinese President. The postponed visit by Ivan Arhkipov to Beijing was reinstated in December 1984 . I. Arkhipov became the highest-ranking soviet leader to visit China since 1969. He met with Chinese Premier zhao ziyang and his counterpart Yao Yilin. The significant outcome of this visit was the three agreements signed by Arkhipov and Yao on December 28, which involved trade, economic technical cooperation, scientific and technological cooperation, and the establishing of a sino-soviet committee for promoting trade

112 Jones. . and Kevill., (compiled) China and the soviet Union 1949-1984. pp. 185-186. 
and scientific and technological cooperation. ${ }^{113}$

The prolonged deadlock of sino-soviet normalization was due to sevexal factors. On the soviet side, the rapid replacement of Soviet leadership (from Brezhnev to Andropov to Chernenko) inhibited any major change in soviet policy. Moreover, gaining influence in Afghanistan, Indochina and Vietnam was so important to the Soviet Union vis-a-vis the United States, as well as vis-a-vis China, it was unlikely for Moscow to make any concessions on the chinese preconditions for sino-Soviet normalization.

As for china, from late 1970 s china had put economic modernization as the highest priority of policy. To achieve this policy required China's access to external sources of capital and technology from the Western countries, the United States and Japan. The United States in particular welcomed China's tilt toward itself in an anti-soviet alignment." Beijing had to take into account Washington's consideration. Conclusion:

The failure in dealing with the chinese issue partially causes the removal of Khrushchev in October 1964. However, it was beyond Khrushchev's ability. Mao was too independent to allow Soviet influence over both chinese external and internal policies. As long as Mao's policies existed, restoration of

113 Ibid., 187.

I14 Allen S. Whiting. "Sino-Soviet Relations: What Next?" Annals of the American Academy of Political and Social Science. Vol. 476, November 1984, p. 148. 
Sino-Soviet relations was impossible to achieve.

With the intensifying of the soviet military build-up, Chinese fear of the potential threat by the Soviets to Chinese security was increased. The Soviet invasion of Czechoslovakia by Soviet troops in August 1968 and the Brezhnev doctrine of "limited sovereignty" greatly pushed Beijing to shift from its anti-American policy to its alignment with Washington.

The fact of Sino-American normalization in 1979 made Moscow acknowledge that its stalemate approach toward china would be at the risk of the Soviet's position in the world arena.

During the period from Brezhnev's death in 1982 to the raise of Gorbachev in 1985, there was neither a striking improvement nor an immediately deterioration of bilateral relations. As Moscow still insisted on restricting negotiations to only bilateral issues, the fundamental issues of Afghanistan, vietnam, the presence of Soviet forces along the sino-Soviet border had not been sclved. The important feature of relations during this period was the increasing of trade, cultural and sporting exchanges. 


\section{CHAPTER TWO}

On March 11, 1985, Mikhail Gorbachev rose to the post of General Secretary of the CPSU. Three days later, he met with Chinese Vice Premier Li Peng, who attended the funeral of former General Secretary Konstantin Chernenko. The meeting was conducted in a warm atmosphere, since both of them studied in Moscow in the 1950s."15

During the meeting, Li Peng passed to Gorbachev a message from Hu Yaobang, General secretary of CCP. The action was of significant, as both sides had not had party-to-party relations for more than 20 years. Also significant was the contents of Hu's message. In the message, Hu wished his counterpart "great accomplishments in the course of the Soviet socialist construction", and expressed the view that China was "willing to work toward further developing relations in the political, economic, scientific, technical and cultural fields"."16 It was the first time that chinese regime officially referred to the Soviet Union as a socialist country since sino-Soviet alienation started.

In return, Gorbachev asked $\mathrm{Li}$ to convey his best wishes

115 When Gorbachev was studying in the Law Faculty of Moscow State University during 1951-1955, Li Peng was educated at the Moscow Power Industry Institute from 1948 to 1954. See, Ying-hsien Pin, "Peking-Moscow Relations since Gorbachev". Issues and studies. Vol. 23, No. 11, November 1987, p. 96 .

116 Mary Lee. "A Crack in the Ice", Far Eastern Economic Review. March 28, 1985, p. 10. 
to Hu and expressed the opinion that the two sides should "continue and heighten their level of dialogue, jointly work to reduce difference and make progress in a wider scope of areas"."17 Gorbachev affirmed that the Soviets wanted to improve their relations with china. Then he added that he considered this was quite possible. Li Peng said that the Chinese side had a similar desire and he hoped that bilateral relations would be further developed in various fields." Furthermore, on March 12, the Chinese President Li Xianian and Chairman of China's National People's Congress Peng zhen sent their condolences to the Presidium of the supreme soviet, expressing their shock about the untimely death of Chernenko. Both of them praised Chernenko's dedication to improvement of sino-Soviet relations and stated that the chinese government sincerely hoped sino-Soviet relations would further develop in various spheres in the future." Thus, since Gorbachev became the Soviet leader, the events mentioned above indicated the possibility of a warming of sino-Soviet relations.

The purpose of this chapter is to examine Soviet foreign policy toward china and China's foreign policy toward the Soviet Union during Gorbachev's era. It will then describe the process of normalizing sino-soviet relations, including the

117 Ibid., p. 10

118 Moscow Tass in English, March 14, 1985, in FBIS-SOV85-050, March 14, 1985, p. B1.

119 Moscow Tass in English, March 13, 1985, in FBIs-SOV85-049, March 13, 1985, p. R17. 
issues of "the three obstacles". The historical Beijing sumit in May 1989 and the implication of sino-Soviet normalization will also be addressed.

Boviet Forelgn Polley Toward China:

When Gorbachev came to power as General secretary, his speech to the Central Committee on March 11, 1985 revealed his desire to seek a serious improvement in rela'tions with China. ${ }^{120}$ Gorbachev's desire to normalize soviet relations with China was also clearly reflected in a major speech in Vladivostok on July 28, 1986, when he presented the order of Lenin to the city. This important speech addressed the soviet policy on developing the Soviet Far East and its policy toward the Asian-Pacific region. Given China's geographic position, the implementation of the new Soviet Asian-Pacific policy and development of the Soviet Far East needed the improvement of si:10-Soviet relations. Thus, in this speech, Gorbachev touched on sino-soviet relations several times and put forward some concrete proposals: ${ }^{121}$

-- Gorbachev stated that the relations between the Soviet Union and China were especially important. First, the two

120 "Speech by Comrade M.S. Gorbachev, General Secretary of the CPSU Central committee, at the Plenary session of the CPSU Central Committee on March 11, 1985", Pravda and

Izvestila, March $12,1985, p .3$. Text is translated in CDSP. Vo1. XXXVII, No. 9, March 27, 1985, p. 8.

121 "The Homeland's Award on the Banner of Vladivostok", Pravda, July 29, pp. 1-3. Text is translated in "Gorbachev Accents Soviet Role in Asia", CDSP. Vol. XXXVIII, No. 30 , August 27, 1986. p. 7 . 
neighbouring countries shared the second longest land border in the world, and the Soviet anc chinese peoples had to :ive side by side. Second, in the interrational arena, a number of issues depended on the cooperation of this two biggest socialist countries.

-- Gorbachev mentioned that recent years had been seen an appreciable improvement of sino-Soviet relations. The Soviet Union was prepared, at any time and at any level, to discuss with the chinese government the most profitable measures for creating an atmosphere of good-neighbourliness. The soviet Union hoped that the border dividing (Gorbachev said he would like to say "uniting") the two countries would become a line of peace and friendship in the near future.

-- The Soviets understood and respected the Chinese drive of "the Four Modernizations" and its objective to build a socialist society. Since the soviet Union had similar priorities to accelerate social and economic developrent, it was reasonable that both countries would benefit by supforting each other and cooperating in some mutually beneficial aspects. The better sino-Soviet bilateral relations, the more two sides could exchange experiences with each other.

-- Gorbachev stressed that a positive improvement had been seen in sino-Soviet economic relations. The mutually complementary characteristic of the two economies established by history offered a great potential for increasing their economic relation, including developing economic contacts 
alons the border areas. He said that some important issues of cooperation were being discussed.

-- In terms of the disputed border on the Amur River, Gorbachev formally announced the main navigation channel could serve as the border line. He said the soviets did not want the Amur river to be considered as a "water barrier". On the contrary, he expected that two sides could cooperate in exploiting rich resources existing thers and using waterresource for common benefit. This new stance was considerably different from the previous Russian claim. In the past, the Russian insisted that the border was the Chinese bank and the islands in the Ussuri and Amur Rivers belonged to the Soviet Union, while the Chinese claimed that the border followed the main channel.

-- At the same time, the soviet leader indicated that the Soviet Union would assist the recently restarted construction of Xinjiang railway linking the Xinjiang-Uygur Autonomous Region and Kazakhstan. He also proposed the involvement of the Soviet cooperation with the Chinese in space exploration, including the training of chinese cosmonauts.

There were several factors which effected the new soviet leadership in its restoration of closer relations with China. First, for strategic reasons, the Soviet Union wanted to terminate the sino-American alignment of the 1970 s and early 1980s. The new Soviet leadership was seeking Beijing's cooperation against Washington's military strategy in the 
Asian-Pacific region. The aims of Gorbachev's Asian-Pacific policy (such as the regional collective security) could not be achieved without Chinese endorsement. The new line of a Chinese independent foreign policy, in which China would never attach itself to any big power, nor enter into an alliance or strategic relationship with any big power was welcomed by Moscow. This policy was regarded by Moscow as an important precondition for normalizing bilateral relations. ${ }^{122}$

Second, one of Gorbachev's initial aims was to create a new, revived socialist community which could be set up on the basis of a renewed sino-soviet relations. The creation of a new socialist group reflected the soviet need for the mutual support of a common programme for domestic and foreign policies.

Third, the concept of "reasonable sufficiency" in Soviet defence was introduced at the 27 th Party congress in 1986 as a product of the soviet effort to reduce its defence expenditures. Without an agreement with China, the reductions of Soviet forces could not be achieved, given the deployment of some 54 divisions of soviet troops along the sino-soviet border.

Fourth, China's position and influence in Asia had been increased. The reforms inside China had brought a great change

122 Bei Jia. "Changing Soviet Relations with Major Powers in the Asia-Pacific Region", International studies. Beijing: Institute of International studies, 1991, No. 2. p. 22. 
in the country. Consequently, China had greatly strengthened its eccnomic power, and it no longer had to rely upon soviet economic assistance. Moreover, China's politival and economic relations with Asian-Pacific countries surpassed that of the Sov'et Union. While the Soviet Union was still regarded as a major threat to Asian Pacific countries and was distrusted by them, China was developing friendly relations with these countries under "the five principles of peaceful coexistence". Thus, China had begun to gain great influence in regional affairs. As the Soviet Union was starting to set up economic contacts witn Asian-Pacific countries, China was enhancing its ecsnomic cooperation with the United States, Japan and the new arising-industrial countries in the Asian-Pacific region. Thus, the Soviet Union had to pay attention to China's position and influence in this region.

Fifth, the renewal of Soviet reform under Gorbachev's leadership generated great interest in chinese experience of economic reform, given the similar economic system in both countriıs. Moreover, the Soviet's long-time lopsided policy on regional economic development had cansed stagnation in the economic develorment of the Soviet Far East and Siberia. Under Gorbachev's administration, Moscow was prepared to develop thes areas. Moscow expected some neighbouring countries, such as japan and China, to participate in development of these areas. Given these factors, the Soviet Union wanted to improve its relations with china. 
In short, under Gorbachev's administration, Moscow placed a high priority on improving its relations with china. China's Poreign Policy Toward the soviet Union:

The orientation of China's foreign policy had been determined by its leaders based on their considerations of domestic policy, national security, economic development and the international environment. With changes of these factors, China's Soviet policy would correspondently change.

During the past few years, a great many of changes had taken place in China's poljtical, economic, cultural and social fields. The development of these fields had strongly affected China's foreign policy, including its policy toward the Soviet Union. The political reform, the economic reform and China's "open-door" foreign policy, affected its policy toward the Soviet Union in the following ways. ${ }^{123}$

-- Since the death of Mao zedong in 1976, the Chinese put most of their energies into internal policies to pursuit econonic development and "the Four Modernizations". In order to accomplish economic development and maintain security, Chinese leaders recognized that the priority of china's foreign policy was to ensure a peaceful and stable international environment, especially around China's periphery in the Asian-Pacific region. With the improvement of its relations with the Soviet Union, the stability along the sino-

123 Guocang Huan. "Sino-Soviet Relations", in Hao, iufan and Huan, Guocang (eds.) The Chinese View of the World. New York: Pantheon Books, 1989. pp. 106-107. 
Soviet border could enable Beijing to make considerable cuts in its military spending.

- The personality cult and personal dictatorship, which had been an important factor in the sino-soviet split in the late 1950s and 1960s, had disappeared. Inside the party and government organizations, a multipolar structure had gradually been set up, although Derig Xiaoping still played a significant role in the decision-maring of the chinese policies.

-- Ideological difference was major factor contributing to the rift in sino-Soviet relations from the late 1950 s until the deach of Mao zedong. isowerer, in the 1980 s ideological issues had ceased to be a factor of conflict. On the contrary, the identical ideology in both countries became an important force for cooperation and unity between the two countries. The Chinese government had been concerned over political and iultural influences, brought into China by its open policy to the West. The campaign against "spiritual pollution" during late 1983 and early 1984, the attacks on "bourgeois liberalization" following student demonstration in December 1986, revealed that the Chinese regime strictly adhered its socialism line. For this concern, the orientation of socialist ideology strengthened China's ties with the communist countries, including the Soviet Union. ${ }^{124}$

-- The strengthening of scientific, military and economic

124 Ellison, Herbert J. "Changing sino-Soviet

Relations", Problems of Communism. Vol. 36, No. 3, May-June 1987 . P. 25 . 
trade cooperation with the soviet Union was conducive to China's socialist modernization. A large amount of machines and equipment in China's large enterprises came from the Soviet Union and East European countries. Soviet technology was more appropriate than western technology for those Chinese enterprises built by the soviets in the 1950s. Thus, cooperation with the soviet Union in these fields played a significant role in the technological innovation and reconstruction of these old enterprises.

- The pro-American stand of the late 1970 s and the early 1980 s in Chinese foreign policy had damaged Chinese image in the Third World. Chinese relations with these countries were narmed. Thus, by pursuing its independent foreign policy, China was trying to improve its relations with the Third World. The improvement of its relations with the Soviet Union might benefit China's Third World relations.

-- The improved relations with the Soviet Union could also had great impact on the vietnam-Kampuchean issue. By jmproving sino-Soviet relations, the Chinese regime hoped to pressure the soviet's ally, vietnam, to withdraw from Kampuchea and to accept China's preferred solution of the Kampuchean issue: an annulment of the pro-Hanoi government of the People's Republic of Kampuchea by the replacement of a n $\cdots$ tralist four-party coalition led by Prince Noradom 
Sihanouk. 125

- Many Chinese leaders, who had received their education in the soviet union during the "honeymoon" period in the 1950s, were promoted co important posts and increased their influences in the party and government organizations.

After more than three decades of substantial economic construction and development, china had become a major power in the Asian-Pacific region. With the rise of China's international status, its foreign policy changed from a revolutionary to a pragmatic outlook.

At the CCF's 12 th National Congress in September 1982, the chinese government announced its new independent foreign policy. This independent foreign policy indicated that china would neither attach itself to any big power or group of powers, nor yield to pressure from any big power. This foreign policy would serve the fundamental interests of the chinese people and the peoples of the world. At the same time, the Chinese government declared that the CCP would develop its relations with other communist parties, based on "the five principles" of independence, complete equality, mutual respect, noninterference in each other's internal affairs and peaceful coexistence. ${ }^{126}$

125 Donald S. Zagoria. " Soviet Policy in East Asia: A New Beginning?" Foreign Affairs: America and the World 1988/1989. Vol. 68 , No. 1, 1988/1989, p. 123.

126 ziyang zhao. "The Objectives of China's Foreign Policy", p. 578 . 
China needed a peaceful international environment to ensure its economic nodernization. The formula for this new approach in foreign policy came from the Chinese leadership's new versions of PRC-USA-USSR triangular relationships.

In the early 1980s, because of Washington's pro-Taiwan policy, sino-American relations were tense. Although the Soviet Union was the principal threaten to Chinese security, the chinese leaders thought it unlikely that china would be forced into a new military confrontation with the Soviet Union in the near future. A moderate reduction of tension with the Soviet Union would benefit China, as it would enhance China's national security and increase Beijing's leverage in dealing with Washington.

After 1976, the United States was no longer seen as a threat to China's security. Instead, it became as a potential strategic partner in countering the Soviet Union's threat to China. Thus, it was in China's interest to maintaining good relations with the United states. Beijing did not want to become involved in superpower global competitions. As a regional power with global strategic significance, China's security interests were mainly focused on the Asian-Pacific region. Therefore, China did not want to have an exclusive alliance with either of the two superpowers. It was desirable for Beijing to cooperate with Washington on Asian security 
issues, while keeping its independence. ${ }^{\text {in }}$

In short, Beijing's policy was to create a relatively peaceful and stable international environment for its "Four Modernizations". Beijing also aimed to reduce Soviet political and military pressure on China and break up Moscow's strategic encirclement of China.

The Process of Mormalisation of Bino-8oviet Relations:

A delegation of the National People's Congress (NPC) of the PRC led by zhang Chengxian, a member of the NPC's standing Committee, visited the Soviet Union during March 3 to 14 , 1985. In a press interview in Moscow, zhang stated tinat it was the first meeting between the chinese and soviet parliamentarians since the 1960s. He added:

The Chinese side attached "much importance to this visit and feel a sense of satisfaction. The principal mission of the delegation is to exchange experience with our counterparts on the question of parliamentary work and to convey the sentiments of friendship to the Soviet people from the Chinese people. ${ }^{128}$

The chinese parliamentary delegation was met by Lev Tolkunov, Chairman of the USSR Supreme Soviet Council of the Union and August E. Voss, Chairman of the USSR Supreme Soviet of Nationalists. ${ }^{129}$ There was no doubt that the resumption of

In Yufan Hao and Guocang Huan. "Chinese Foreign Policy in Transition", in their eds. The chinese view of the World. New York: Pantheon Books, 1989, pp. xxi-xxil.

128 Izvestila. March 4, 1985, p. 4, in FBIS-SOV-85-042, March 4, 1985, pp. B1-B2.

129 Pravda. March 5, 1985, p. 4. in FBIS-SOV-085-044, March 6, 1985, pp. B1- 。 
contacts between the two countries' supreme organs of state poirer was an important stage in sino-soviet relations. It pliayed a positive role in bettering mutual understanding kerween the two countries.

The visit by a delegation of Soviet industrial trade union to China in August 1985 created a reestablishment of ties between two countries trade union organizations after a 20-year break. Shortly after this, another delegaticn from the Soviet sectorial trade unions headed by L. A. Yakovlev, Chairman of the Central Committee of the Automotive Transport and Highway Workers Trade Union, visited China on August 20, 1985.130

At the invitation of the All-China People's Congress, $L$. N. Tolkunov, Chairman of the USSR Supreme Soviet Council of the Union, led a delegation of the USSR's Supreme soviet on an official visit to China on October 10, 1985. During his stay in Beijing, he met with Peng zhen, Chairman of the National People's Congress standing Committee, and Li Xiannian, President of the PRC. During the meeting between Tolkunov and Peng zhen, both sides stated a desire to build parliamentary ties on a regular basis, and signed an accord to establish ties between the USSR Supreme soviet and the NPC standing Commissions. They discussed questions concerning the

130 Moscow Domestic Service in Russian, August 10, 1985, in FBIS-SOV-85-155, August, 1985, p. B1.; Hoscow TRUD in Russ ian, August, 21, p. 1985, p. 3, in FBis-sov-85-163, August 22,1985, p. B1. 
activity of the supreme and local organs of power in the two countries. They also exchanged opinions on the further development of sino-soviet relations. ${ }^{131}$

The visit by the supreme soviet delegation had significant implications. The resumption of contacts between the supreme and local bodies of power in the Soviet Union and China opened additional possibilities in the work of improving sino-Soviet relations and deepening mutual understanding between USSR and PRC. Both sides claimed that the visit was a great success. ${ }^{132}$

Mikhail Kapitsa, the Soviet Deputy Foreign Minister visited China for consultations on international issues from December 5, 1985. The Chinese side still demanded the removal of "the three obstacles" to normalization of relations. However, Kapitsa repeated the Soviet line, stating that these issues concerned soviet relations with third countries and should not hamper any normalization with china. The result of Kapitsa's visit was that both sides agreed to have foreign ministers' meeting three times in 1986. The Soviets proposed the signing of a nonaggression treaty, but this was rejected by the chinese, as saying that it was impossible for the

131 Izvestila, October 12,1985, p. 4. in FBIS-SOV-85199, October 15, 1985, pp. B1-B̈́.

132 Tokyo Kyodo in English, in FBIS-SOV-85-206, october, 24, p. B3. 
moment. ${ }^{133}$

Nikolai Talyzin, a candidate member of the politburo of the CPSU Central Committee, First Deputy Chairman of the USSR Council of Ministers, and Chairman of the USSR's Gosplan visited Beijing from Soptember 8-15, 1986.13 During his stay in China, Talyzin met with several Chinese leaders including Song Ping, Minister of the state Planning Commission. Given the similar planned economic system in both sides, it was significant for Talyzin and song to exchange opinions on their planning departments handling various economic issues. Both sides hoped to establish direct contact between soviet and Chinese state Planning Commissions.13s During Talyzin's visit, several agreements on mutual relations and cooperation between the state Planning Commissions of the two countries were signed. A consular treaty was signed, and notes on bilateral trade were exchanged. ${ }^{136}$ Talyzin's visit contributed to the further development and deepening the sino-soviet cooperation in various areas.

The intensive contacts between of icials from both sides

133 Paris AFP in English, January 8, 1986, in FBIS-SOV86-005, January 8, 1986.

134 Moscow Tass International service in Russian, September 8, 1986, in FBIS-SOV-86-174, September 9, 1986, p. B1.

135 Moscow in Mandarin to China, september 10, 1986, in FBIS-SOV-176, September 11, 1986, p. B2.

13. Hoscow Radio Peace and Progress in Mandarin to China, September 11, 1986, in FBIS-SOV-86-178, September 15, 1986, p. B1. 
produced an improvement of bilateral relations which could be seen from several events. Russian, wh:ch had been the most popular foreign language in china during sino-Soviet "honeymoon relations" of the 1950s, was restored to the curriculum of Chinese high schools. Oat 19 August 1985, the Beijing Radio station resumed its broadcast of Russian language lessons, which was suspended in 1956, to the residents of Beijing. ${ }^{137}$ In May 1985, both sides agreed to mutually open consulate generals in Leningrad and Shanghai, and to simplify visa procedures. ${ }^{138}$

On the 40th anniversary of the victory in the antifascist war against the Japanese invaders, Chinese newspapers affirmed that the Soviet Union occupied the most prominent position among the counticies that rendered aid and support to China during the Anti-Japanese War. Jingii Ribao (The Economic Newspaper) wrote down:

The Soviet Union's participation in the war against the Japanese invaders, the route of the Japanese Kwantung Army, in the liberation of north-eastern China and northern Korea accelerated Japan's capitulation and brought the end of World War II closer. ${ }^{139}$

Over 100 Soviet pilots, who participated in the battles for the city of Wuhan and other cities of China and gave their

137 Moscow in Mandarin to China, August 22, 1985, in FBIS-SOV-85-165, August 26, 1985, p. B1.

138 Tokyo Kyodo in English, June 21, 1985, in FBIS-SOV85-120, June 21, 1985, p. B1.

139 Krasnaia Zvezda, August 13,1985, p. 3 . in FBISsov-85-157, August, 14, p. B1. 
lives, were remembered by the chinese people.

On the $36 \mathrm{th}$ anniversary of the establishment of the PRC, the USSR Supreme Soviet Presidium and the USSR Council of Ministers sent their congratulation and good wishes to the Chinese President $L i$ Xianian, Chairmen of NPC standing Committee Peng zhen and Premier of the State Council zhao ziyang. In the message, the desire for improvement of relations between the Soviet Union and China was mentioned again. The message stated:

our country has consistently pursued its principled line in the field of Soviet-Chinese relations and advocates their serious improvement, the further development of mutually advantageous ties and contacts, and the expansion and intensification of political dialogue. The Soviet Union proceeds from the conviction that it is essential to restore good-neighbourliness and all-around cooperation between the two countries on a mutually acceptable and equitable basis, which would conform with the fundamental interests of the Soviet and Chinese people and promote the consideration of security in Asja and the positions of peace and 5 cialism. ${ }^{140}$

Responding to the Soviet congratulation, Li Xianian, Peng Zhen and Zhao zijang sent a telegram to the USSR Supreme Soviet Presidium and USSR Council of Ministers, expressing their sincere gratitude for the congratulation on the 36 th anniversary of the proclamation of the PRC."'

political consultations:

From 1985 to April 1989, biannual consultations for

140 Izvestila, October 1, 1985, p. 1. in FBIS-SOV-851990, October 1, 1985, p. B1.

141 Pravda, October 13, 1985, p. 2. in FBIS-SOV-85-201, October 17, 1985, p. B2. 
normalization of relations were held in Beijing and Moscow alternately. However, details about the consultations had not been disclosed by either side.

The sixth round of political consult lons in Moscow in April 1985 ended with a joint communique, expressing a mutual desire to develop bilateral relations in all areas, including the political. But, no substantial progress had been made during the negotiations, as Qian Qichen stated on his return from Moscow. ${ }^{102}$

The seventh round of sino-Soviet political consultations led by L.F. Ilichev, Soviet Deputy Foreign Minister, and Qian Qichen, Chinese Deputy Foreign Minister was held in Beijing during october 4- 8, 1985.143 within a frank, calm ard businesslike talk, they continued to exchange opinions on questions of normalization of bilateral relations and on some international problems. During the talks, Qian implied that if the Soviet side would cease support for Vietnam's presence in Kampuchea, sino-Soviet relations could see some improvement. Ilichev proposed to establish confidence building measures, which included each side's informing the other in advance of military manoeuvres and clearing troops away from their respective side of the border. ${ }^{14}$ Nevertheless, they did not

142 Hong Kong AFP in English, October 2, 1985, in FBISsov-85-191, October, 2, 1985, p. B1.

${ }^{143}$ Pravda, in FBIS-SOV-85-203, October 21, 1985, p. B1.

14 Tokyo Kyodo in English, October 18, 1985, in FBISsov-85-206. October, 24, 1985, jp. B2-B3. 
achieve any major breakthrough in improvement of relations.

since mid-1986, there had been some significant improvements in sino-Soviet relations. The ninth round of political consultations was held in Beijing during October 614, 1986 between Igor Rogachev, the new chief Soviet negotiator and Soviet Drouty Foreign Minister, and $h$ is Chinese counterpart Qian Qichen. During the consultations, they discussed the questions concerning normalization of relations. A substantial result from this round was that bo:h sides agreed to resume the sino-Soviet border talks at the level of deputy foreign ministers in Moscow in February 1987.145

The significance of the ninth round of political talks was that Moscow was willing to discuss both the Afghanistan and the Kampuchean issues with China as gart of the sinoSoviet normalization talks, abandoning its long-time refusal to include the "third party" issues into the context of negotiations. Rogachev informed the chinese side that the withdrawal of six Soviet regiments from Afghanistan would begin on October 15 1986. However, although the Kampuchean issue was discussed during the talks, no major progress was achieved. ${ }^{146}$

At the eleventh round of bilateral political consultations in Beijing during october 6 to 16, 1987, the

iss Izvestiia, October 15,1986, p. 4. in FBIS-SOV-86199, October 15, 1986, p. B1.

146 Tokyo Kyodo in English, October 15, 1986, in FBISsov-86-200, October 16, 1986, p. B1. 
Kampuchean issue was discussed at length. Serious divergences of opinion over Kampuchea still remained. However, there was one common point hejd by both sides, i.e. that the conflict can be resolved only by political means. ${ }^{147}$ Apart from Kampuchea, the two sides also exchanged opinions on international issues and problems in the Asian-jacific region.

The politicai concultations between two countries at the deputy foreign minister's level served as a channel for exchange of $E$, ih sides' opinions on hilateral relations. As I. A. Rogachev, Soviet negotiator and Deputy Foreign Minister, stated:

This (i.e. the consultation) opened up an important channel for a dialogue that was meant to aid the process of normalizing bilateral relations, searching for mutually acceptable of the sides' positions on international problems. ${ }^{14}$

\section{The Three Great Obstacles:}

China had argued that the Soviet Union must compromise on several issues before normalized bilateral relations would become reality. When Beijing agreed to resume talks with Moscow in October 1982, it put "three great obstacles" to full normalization of sino-Soviet relations: the reduction of Soviet trocps along the sino-Soviet horder and removal of Soviet forces from Mongolia; the withdrawal of Soviet troops

147 Moscow TASS in English, Dctober 16, 1987, in FBISSCV-87-201, October 19, 1987, pt.. 28-29.

148 "Ninth Round: Political Dialogue was Useful", Izvestila, Octuber 24,1986, p. 5. Text is translated in CDSP. Vol. XXXVIII. No. 43, Novomber 26,1986, p. 17. 
from Afghanistan; and the Soviet enforcement on the vietnamese withdrawal from Kampuchea. As these three obstacles had served as major barriers to normalization, each of them merits individual examination.

Soviet Forces Along the Sino-Soviet Border and Mongolia:

China was very concerned about the depioyment of the Soviet forces in Mongolia. First, the deployment of soviet forces in Mongolia was perceived by China as a military threat to China, as the Soviet forces were deployed along the best invasion route to Beijing, the chinese regime was wcrried that the Soviet Union could use Mongolia as an easy platform from which to attack northern china. Second, the soviet domination of Mongolia had a political meaning. Beijing had traditionally considered this area to be under its influence. Thus, the removal of soviet corces would not only reduce the soviet military threat to china, it would also remove chinese resentment. ${ }^{149}$

Following Gorbachev's 1986 speech in Vladivostok, which addressed a partial withdrawal of Soviet troops from Mongolia, in January 1987 Moscow announced that one motorized rifle division and some additional military units would be withdrawn from Mongolia between April and June of that year. Although the reduction of soviet troops was minimal (Moscow withdrew 12,000 of the 65,000 soviet trocps deployed in Mongolia), it

149 Dan L. Strode. "Soviet China Policy in Flux", Survival. Yol. 30, No. 4, July/August 1988, pp. 337-338. 
was considered by China as a gesture of good faith. ${ }^{150}$

In 1986 there were several indications of improvement in Sino-Mongolian relations. The first trade agreement between China and Mongolia, covering the period of 1986-1990, was signed in April 1986. On June 6 air service between Uian Bator and Beijing was resumed after being suspended for 19 years. Gorbachev's speech in vladivostok on the withdrawal of Soviet troops from Mongolia, and the actual partial withdrawal of Soviet troops from Mongolia, brought forth a great impetus for improving sino-Mongolian relations. The visit to Ulan Bator by Liu Shuqiny, a Chinese Deputy Foreign Minister, in August of 1986 ended with the signature of a consular treaty between China and Mongolia. This was the first treaty signed, since two sides established diplomatic relations in 1949 . This treaty was considered to be of great significance as part of the rapprochement between Beijing and Moscow. The two sides also agreed to hold anrual talks at the level of deputy foreign minister in the rutur . 151

In February 1989, while staying in Beijing, soviet Foreign Minister Shevardnadze announced that three quarters of the remaining soviet troops (estimated 50,000 ) in Mongolia would be removed over a period of two years. ${ }^{152}$ In December

150 Ibid.

151 Keesing's Research Archives: Record of World Events. vol. XXXII, No. 10, Octoher, 1986, p. 34679.

132 Louise do Rosario. "Don't Call Me Comrade", Far Eastern Economic Review. February 16, 1989, p. 11 . 
1988, Moscow announced its plan to withdraw 200,000 troops from the Far Eastern Theatre by the end of 1990. ${ }^{153}$ Thus, by the withdrawal of its troops irom Mongolia and the Soviet Far East, Moscow addressed one of the three obstacles put forward by China.

\section{Afghanistan:}

Along with his warm initiative toward sino-soviet normalization, and the new stand of the soviet leadership toward the disputed Sino-Soviet border, Gorbachev's vladivostok speech also touched on the Afghanistan conflict. In the speech, Gorbachev announced that six Soviet regiments would be withdrawn from Afghanistan before the end of 1986. 1s.

The initial Chinese response to Gorbachev's Vladivostok initiative was cautious. China emphasized that the proposed Soviet troop withdrawal from Afghanistan was only a fraction of the Soviet forces in Afghanistan, and the partial withdrawal was little more than a gesture. On 3 september, 1986 Chinese leader Deng Xiaoping told a delegation from Komeito (a Japantze opposition party) that since only 5-7 percent of Soviet forces in Afghanistan was proposed to be

153 Gerald Segal. "Soriet Options in the Pacific", in Susan L. Clark (ed.) Gorbachev's Agenda: Changes in Soviet Domestic and Foreign Policy. Boulder: Westview Press, 1989, p. 325 .

154 "The Homeland's Award on the Banner of Vladivostok", translated in CDSP. August 27,1986, p. 8 . 
withdrawn from Afghanistan, the amount was unsatisfactory. ${ }^{\text {iss }}$ Moreover, since the withdrawn troops were armoured and antiaircraft forces, they had little use in battles in mountainous terrain against the Afghan resistance forces, who had no aircraft. ${ }^{156}$

As proposed in Gorbachev's Vladivostok speech, on October 15, 1986, the Soviet Union began withdrawing six regiments from Afghanistan -- three anti-aircraft regiments, two motorized infantry regiments and one tank regiment. By 1986, more than eight year occupation of Afghanistan had cost Moscow US\$ 20 billion and tens of thousands of soviet soldiers. The Soviet heavy political and economic burden of the Afghanistan conflict had caused the soviet leaders to pull the soviet troops out. Gorbachev called Afghanistan conflict a "oleeding wound". ${ }^{157}$

On April 14, 1988 in Geneva, the Soviet Union, Afghanistan, the United States and Pakistan signed several agreements to end the Afghanistan conflict. Under the agreements, Moscow would withdraw all of its estimated 115, 000 troops from Afghanistan within nine months starting from May

15s Robert Delfs. "Soviets Bearing Gifts - China is Wary of Gorbackev's New Proposals on Asia", Far Eastern Economic Review. November 13, 1986, p. 33 .

156 zhongxing Shi. "Soviet Troop Pullout only Gesture", Beijing Review, Vol. 29, No. 43, November 3, 1986, pp. 1213 .

157 Ibid., p. 14 
15. ${ }^{158}$ China welcomed the signing of the Geneva Accord on Afghanistan and the soviet troops withdrawal under this accord. A spokesman for Chinese Foreign Ministry said on April 15 that it was a "positive development", and expected the complete withdrawal of all soviet troops from Afghanistan within the time set. ${ }^{159}$ The removal of soviet troops from Afghanistan reflected Moscow's desire to improve sino-soviet relations by responding to another of "the three obstacles". Vietnam-Kampuchein Conflict:

For China, the Kampuchean conflict was considered crucial from the viewpoints of chinese security, international statis and prestige. The conflict also affected china's future role in South-East Asia. China had strongly opposed any Vietnamese dominance in Asian-Pacific region. Th: Soviet alliance with Vietnam and its support for Hanoi's occupation of Kampuchea was perceived by China as a Soviet attempt to gain influence in Asia-Pacific region. It was no subt that the soviet military presence in vietnam was mainly directed toward tre United states, yet it also posed a threat to China's southern territory. ${ }^{160}$

The issue of the Soviet backed Vietnamese occupation of

158 Guang Ma. and Zhinian Zhang. "Peace Agreement signed in Geneva" "Beijing Review. Vol. 31, No. 17, April 25, 1988, pp. 13-14.

159 Ibid., p.14

160 Charles McGregor. The Sino-Vietnimese Relationship and the Sovizt Union. London: International Institute for strategic studies, 1988. (Adelpi Paper \$232) p. 64. 
Kampuchea was the most difficult of "the three obstacles" for Moscow to address. As one of two superpowers in the world, the Soviet Union was traditionally perceived as a European power. Its status as an Asian power was rather weak. Thus, from the 1970 s the Soviet Union wanted to increase its influence in Asia.

For the Soviet Union, its alliance with vietman made strategic importance. Maintaining an alliance relationship with vietnam served soviet interest in increasing its influence in the Asian-Pacific region. It also gave Moscow valuable access to Vietnamese military facilities left by the United states, at Cam Ranh Bay and the Da Nang air-base. This strengthened the soviet military build up in Asia. It also provided the Soviet Union with well-placed intelligence gathering facilities close to the US military bases in the Philippines. ${ }^{161}$ This, for strategic considerations, the soviet Union was reluctant to risk its solid relations with vietnam, its closest ally in Asian-Pacific region, in order to make concessions to China on the Vietnam-Kampuchean issue.

In his Vladivostok speech, Gorbachev did not address the issue of Vietnamese occupation of Kampuchea. Inctead, he insisted that the soviet Union should not interfere in Vietnam's internal affairs, ard he argued that sino-soviet normalization could not come at the expense of the soviet's friendship with other countries. He asked China to deal

161 Strode., "Soviet China Policy in Flux", p. 334. 
directly with vietnam on the Kampuchean issue. ${ }^{162}$

In an official statement on August 13, Chinesr Foreign Minister Wu Xuegian responded to the Vladivostok: speech by saying that Gorbachev's initiative still did rit remove "the three obstacles", particularly the issue of vietnam's withdrawal of its troops from Kampuchea, which China was most concern about. ${ }^{163}$ In a CBS interview on september 2, Deng Xiaoping responded to Gorbachev's initiative by saying that the vietnamese presence in Kampuchea $w$-: the most important impediment to the improvement of sino-Soviet relations. In that interview he told the American journalist Mike wallace that he would be willing to meet with Gorbachev anywhere in the Soviet Union, if Gorbachev would remove the "main obstacle in their relationship by urging vietnam to end its aggression in Kampuchea and withdraw its troops from there."164 Deng asserted that the vietnam could not go on fighting for a "single day" without the Soviet support. ${ }^{165}$

Four months later, in October 1986 the Soviet Union finally agreed to pic the Kampuchean issue on the agenda of consultations between vice foreign ministers, thus, giving up

162 "The Homeland's Award on the Banner of Vladivostok", translated in CDSP. August 27,1986, p. 7 .

163 Delfs., "Soviets Bearing Gifts", p. 32.

104 Nayan Chanda. "Diplomacy on the Air", Far Eastern Economic Review. September 18,1986, p. $2 \epsilon$.

165 Keesing's Contemporary Archives: Record of World Events. Vol. XXXIII, No. 4, 1987, y. 35066 . 
its previous refusal to discuss with China issues involving third states. 160 since 1987, the Soviet position had changed substantially. In a May 1.987 meeting with Nauyen Van Linh, General secretary of the Communist Party of Vietnam (CPV), Gorbachev called for the reunification of all Kampuchean national patriotic forces. Gorbachev was prepared to accept the Khmer Rouge (the chinese backed faction) as a partner in a coalition government, and intended to include the Khmer Rouge in a peaceful settlement to Kampuchea political problems. ${ }^{167}$

On October 8, 1987 Kampuchea issued a statement endorsed by both Moscow and Hanoi which for the first time proposed a "neutral" coalition government. This indicated Moscow's willingness to accommodate the interests of China, the United States and the Association of South-East Asian Nations (ASEAN). ${ }^{168}$ In late 1987 around 20,000 vietnamese troops were withdrawn. ${ }^{169}$

The Soviet troops' withdrawal from Afghanistan in 1988 focused new attention on the vietnamese occupation of

166 Joachim Glaubitz. "Rapprochement Between China and the Soviet Union: Background and Prospects", Aus ien Politik vol. 40, No. 3, 1989, p. 254.

167 Hong Kong AFP in English, May 20, 1987, in FBIs-SOV87-101, May 27, 1987, p. E1.

168 strode., "Soviet China Policy in Flux", p. 334.

169 Leslie Holmes. "Afghanistan and Sino-Soviet Relations", in Saikal, Amin. and Maley, william (eds.) The Soviet Withdrawal from Afqhanistan. Cambridge, New York: Cambridge University Press, 1989, p. 134. 
Kampuchea. The year of 1988 witnessed a significant change in the Kampuchean issue. In May, Hanoi announced that 50,000 Vietnamese troops in Kampuchea would be withdrawn by the end of that year, and all troops (estimated another 50,000-70,000) would be pulled out by the end of 1990. The last contingents would be placed under Kampuchean control. Moscow claimed that the vietnamese decision on this issue resulted from the soviet Deputy Foreign Minister Igor Rogachev's urging during his visit to Hanoi in early 1988.170

In June 1988, China's Vice Foreign Minister Tan Zengpei and Soviet Vice Foreign Minister Rogachev held a work conference on the Kampuchean issue in Moscow. According to Beijing's claim, during the conference Moscow for the first time agreed that the withdrawal of vietnamese troops from Kampuchea was the key to the solution of problems in sinoSoviet relations." The change in the soviet stand on the Kampuchean issue further paved the way for a Beijing-Moscow summit.

Border Dispute:

The border dispute was not listed by China as one of three obstacles to normaliped sino-Soviet relations. Yet, the border issue had also been the subject of bilateral negotiation talks. In his 1986 vladivostok speech, Gorbachev

170 Nayan Chanda. "A Summit in the Offing", Far Eastern Economic Review. October 13, 1988, p. 17.

171 Chien-Min Chao. "A Peking-Moscow summit Impending", Issues and studies. Vol. 25, No. 1, 1989, p. 2 . 
formally announced the main navigation channel of the Amur River could serve as the border line. This concession led to a resumption of formal border talks. The meeting between Eduard Shevardnadze and Wu Xueqian at the United Nations in 1986, produced a reopening of sino-Soviet border negotiation in early 1987.

The first round of talks, which took place on February 9 to 231987 in Moscow, concluded with an agreemert to discuss the entire length of the border, beginning with the Far Eastern sector. ${ }^{17}$ During the second round of talks (headed by Vice-Foreign Ministers Igor Rogachev and Qian Qichen) concluded on August $z$ : 1987, China agreed that the eastern sector's boundary should be determined by existing treaties, and the Soviet Union ackncwledged that the main navigational channel should serve as the border along the Amur and Ussuri rivers. In addition, both sides agreed to create a working grnup of experts to negotiate the whole length of the eastern sector. ${ }^{173}$ The first meeting of this working group was held in Moscow from January 20 to February 1 1988. Experts from both sides arranged for joint aerial photography of the eastern

17 Moscow Radio Peace and Progress in Mandarin to China, February 27, 1987, ir. FBIS-SOV-87-041, March 3, 1987, p. B2.

173 Moscow TASS Inteinational Service, August 21, 1987, in FBIS-SOV-87-162, August 21, 1987, p. B1. 
border region. ${ }^{174}$ However, despite this significant progress, some difference remained and could not be easily resolved, especially question of who owned the Heixiazi islands near the city of Khabarovsk.

\section{Further Negotiations Toward Normalization:}

In an interview with the chinese official journal Liaowang on January 11 1988, which was the first interview given a major soviet leader by a chinese journal in thirty years, Gorbachev used the opportunity to call for a summit as a logical development of sino-soviet relations. ${ }^{175}$ In his Krasnayarsk speech in september 1988, Gorbachev again reiterated his readiness for a summit meeting with chinese leaders. ${ }^{176}$

By 1988, Moscow had showed its willingness to take some action toward solving "the three obstacles" put forward by Beijing. As these obstacles were gradually being removed, though they had not completely disappeared, Beijing express its willingness to exchange visits of foreign minister and to have a Beijing-Moscow summit.

on October 4 1988, Deng Xiaoping told Helmut Schmidt,

174 Moscow Tass International Service in Russian, February 1, 1988, in FBIS-SOV-88-0:1, February 2, 1988, p. 29. Moscow TASS in English, February 10, 88, in FBIS-SuV88-0z7, February, 1988, p.26.

175 Izvestiia, January 11,1988, p. 1, in FBIS-SOV-88006 , January 11, 1988, P. 25 .

176 Pravda, September 18, 1988, pp, 1-3, in FBIS-SOV-88182 , september 20,1988, p. 38 . 
former Chancellor of the Federal Republic of Germany on a visit to Beijing that norma'ization of sino-soviet relations would be not far away, implying that a summit might take place soon. On October 17, at a meeting in Beijing with Nicolae Ceausescu, Genera: Secretary of the Romanian Communist Party, Deng again asserted that a Beijing-Moscow summit might possibly take place in 1989.17

The talks between Chinese Foreign Minister Qian Qichen and his Soviet counterpart Eduard Shevardnadze on september 28, 1988 at the 43 rd General Assembly of the United Nations marked the new drive toward rapprochement in sino-soviet relations. After the talk, both sides announced that Qian would visit Moscow in December 1988, and Shevardnadze would visit Beijing in early 1989. On vecember 1, 1988 Qian Qichen arrived in Moscow. It was the first tine that a chinese foreign minister visited Moscow, since the split between China and the Soviet Union in the 1960 s.

The central issue of Qian's 3-day visit was to prepare for a meeting between Gorbachev and Deng xiaoping in the following year. ${ }^{17 k}$ Qian was also received by Gorbachev in Moscow. The normalization of sino-Soviet relations and the Kampuchean issue were among the main topics of discussion. The visit by Qian was a success. In a new conference on December

in "Sino-Soviet summit Anticipated in 1989" Beijing Review, Vol. 31, No. 43, octoluer $24,1988, \mu .9$.

178 Moscow World Service in English, November 30, 1988, in FBIS-SOV-88-231, December 1, 1988, pp. 10-11. 
3, he stated that the summit would take place, even if certain differences remained on the Kampuchean issue. ${ }^{179}$ Qian invited Shevardnadze to visit China in the following year for further arrangements of a sino-Soviet summit and further negotiations on the Kampuchean issue.

Shevardnadze paid an official visit to China on February 2-4 1989. Again, the main goal of the visit was to prepare for the summit meeting. ${ }^{180}$ During his stay in Beijirg, Shevardnadze announced a Soviet proposal to demilitarise the sino-Soviet border. The measures included the reduction of Soviet troops in the eastern and southern parts of the soviet Union by 200,000 and 60,000 men respectively, within the frariework of cuts announced by Gorbachev in December 1988 in New York; the withdrawal of three-quarters of the soviet troops from Mongolian within two years; and units stationed near the sino-Soviet border would be reorganized for only defensive furpose. ${ }^{\text {k: }}$ The Shevardnadze's visit also produced a nine-point joint statement on Kampuchea -- the first joint Sino-soviet statement on this issue. Beijing and Moscow reiterated the need for settling the Kampuchean issue only by political means, and hoped the decision announced by vietnam

174 Moscow TASS in English, December 3, 1988, in FBISSOV-88-233, December $E, 1988$, p. 18 .

180 Pravda February 3, 1989, pp. 5-7, in FBIs-SOV-89022 , February, 1989, p. 18.

1*1 Pravda, Ferruary 5, 1999, in FBIS-SOV-39-c23, February 6, 1989, p. 27. 

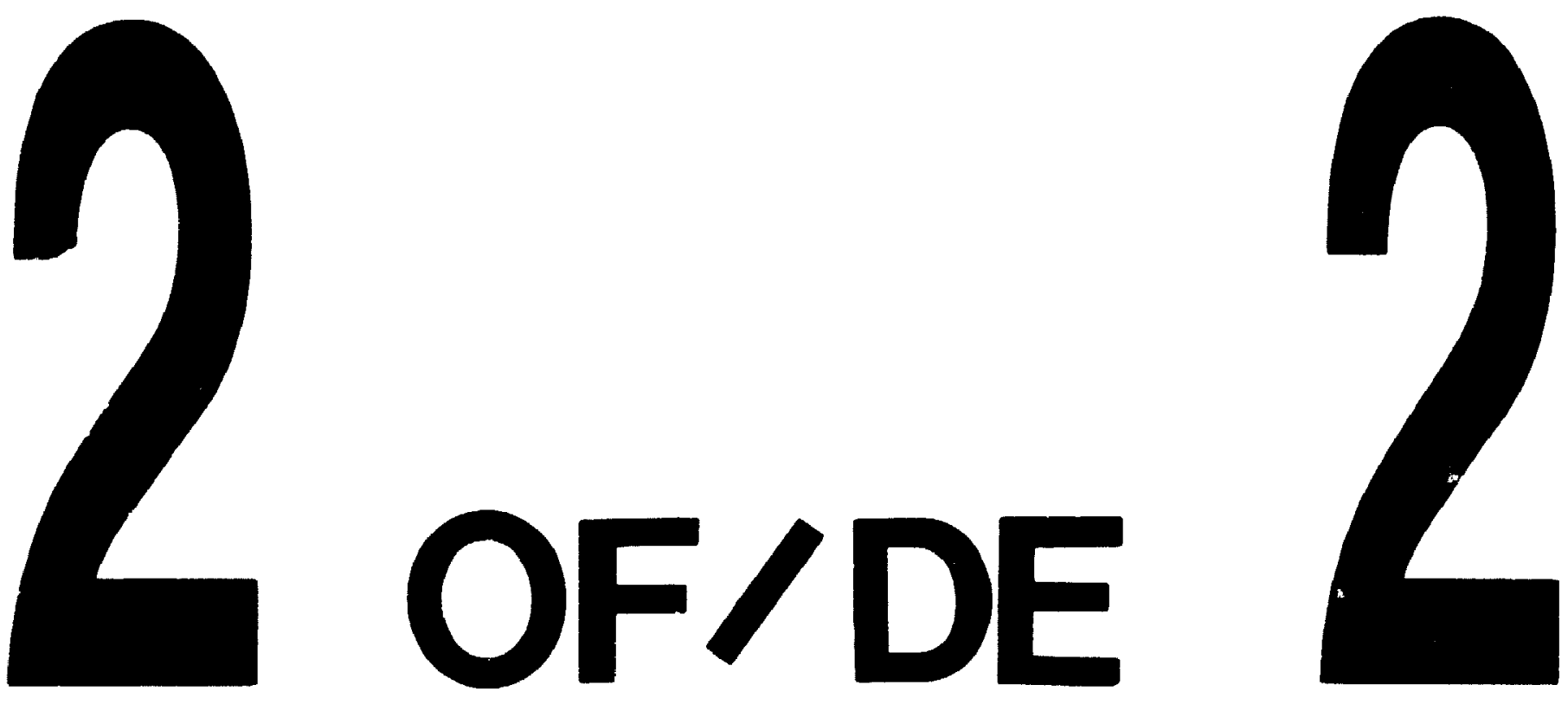

PM-1 3'2" $\times 4^{\prime \prime}$ PHOTOGRAPHIC MICROCOPY TARGET NGS 1010a ANSI/ISO "2 EOUIVALENT

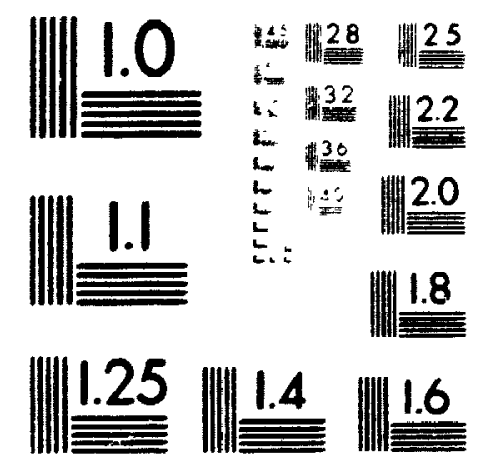

PRECISIOHSEs RESOLUTION TARGETS 
on the complete withdrawal of its troops from Kampuchea before September 1989 would further the process toward a Kampuchean settlement. ${ }^{182}$

Hay 1989 Beifing summit:

From May 15 to 18, 1989, Soviet President Mikhail Gorbachev paid his historic visit to China. The meeting on May 16 between Gorbachev and Deng Xiaoping drew global attention. Both sides exchanged opinions on a wide range of topics, such as the history of Russian-Chinese and soviet-chinese relations, the future of socialism, theoretical foundations of socialism, the current international situation and the settlement of the Kampuchean problem. In terms of socialism and the development of Marxist theory, both agreed that there was no uniform model and no uniform standard for the new socialist society. The meeting signified that the normalization of sino-soviet relation had come true. As Deng stated: "let the wind blow away the past, and let us look forward." 183

The meeting between Gorbachev and zhao Zhiyang, General Secretary of CCP marked the beginning of a resumption of relations between the two communist parties. During his fourday visit, Gorbachev also met with the Chinese President Yang

182 Pravda, February 6, 1989, p. 5. in FBIS-SOV-89-023, February 6, 1989, p. 29-30.

183 "The USSR and the CPR Normalize Relations: M.S. Gorbachev Meets with Deng Xiaoping", Pravda, May 17, 1989, p. 1. Text is translated in CDSP. Vol. XLI, No. 20, June 14,1989, p. 1 . 
Shangkun and Premier Li Peng. However, the schedule of visits was interrupted several times by a large-scale hunger strike in the Tiananmen square launched by chinese students. For example, the welcome ceremony for Gorbachev had to be moved from the proposed Tiananmen Square to the Beijing airport. The ceremony at the Monument to the People's Heroes did not take place, because the student demonstration had not ended.

Nevertheiess, the historic significance and long-term political effect on normalized relations between the soviet Union and China can not be di -inished. Normalization of SinoSoviet relations indicates $t_{1}$ i the more than thirty years of confrontation between two largest socialist countries had ended, and a new era of sino-soviet relations had begun. The new relations were based on "the five principles of peaceful coexistence": the principles of independence, equality, mutual respect, noninterference in each other's internal affairs and peaceful coexistence.

Gorbachev's historic visit to china ended with the publishing of "a Joint Soviet-Chinese Communique". ${ }^{184}$ The Joint Communique consisted of 18 points. It covered issues that both sides were interested in, such as the issues of reduction of armed forces along sino-soviet border, the resolution of border questions, cooperation in the fields of

184 For detail context of the joint communique, see "Joint Soviet-Chinese Communique", Pravda and Izvestiia, May 19, 1989, p. 1. Text is translated in cDSP. Vol. XLI, No. 20, June 14, 1989, pp. 2-4. 
economic, trade, scientific-technical, cultural and other fields; the exchange of information and experience in the field of socialist construction and reform, the normalization of party relations, the Soviet's stand on the Taiwan issue, both sides' foreign policy, both sides' stands on AsianPacific and international issues. The soviet government supported the chinese stand on Taiwan as an inalienable part of Chinese territory. The Kampuchean issue occupied a long paragraph in the Joint Communique. Although there was no new agreement on the Kampuchean issue, both sides had a comprehensive and in-depth exchange of opinions concerning a Kampuchean settlement. The announcement that normalized sinoSoviet relations were not directed against any third countries and did not infringe on the interest of third countries, was particularly noted by the public.

\section{Implication of Normalized sino-soviet Relations:}

The 1989 Beijing Summit marked a complete normalization of sino-Soviet relations, and represented the culmination of a long process of sino-Soviet normalization starting in 1982 . It also represented the substantial success for Beijing in countering the soviet military threat to china, which had existed since the late $1960 \mathrm{~s}$. The rapprochement would also strengthen the political position of both Gorbachev and Deng Xiaoping in their respective countries.

In terms of the military situation, there was no doubt that china and the sovict union achieved benefit from the 
normalization of relations. Both countries could cut a huge amount of military expenditure on the 7500 kilometre-long border, where both sides had deployed tremendous forces since the mid 1960s.

In terms of economics, given the similar system existing in both countries, China and the Soviet Union could benefit from learning in each other's experience in dealing with economic reforms. The better relations would give an impetus to increase economic and trade cooperation.

In terms of the political aspect, given the two countries' significant positions in the world politics, normalized sino-Soviet relations could have an impact on the power structure in world politics and especially on the interests of concerned countries in the Asian-Pacific region. Normalization of bilateral relations between Beijing and Moscow could contribute to the relaxation sf tension and stability in the world. The sino-Soviet rapprochement could have a stabilizing effect on sino-vietnamese relations. Of course, sino-Soviet rapprochement did not mean the revival of a Moscow-Beijing alliance as prevailed in the $1950 \mathrm{~s}$.

The 1989 summit, as Deng stated, symbolized sino-Soviet relations to "put an end to the past and open up the future". 


\section{CHAPTER THREE}

\section{Brief History Reviev of sino-soviet Economic Relations:}

sino-soviet economic relations had varied during different periods. From 1949-1984, the economic relations can be divided into four periods. The first period was from 1949 to 1959. It was characterized by close and all-round cooperation between the Soviet Union and China, and the dominance of the Soviet Union in China's foreign trade.

The bilateral economic ties during that period were laid by a series of treaties signed in February 1950 at the end of Mao Zedong's visit to Moscow and thereafter. Under an economic aid agreement, the Soviet Union agreed to grant china a credit of US\$ 300 million to help China obtain industrial and railway equipment from the USSR. However, instead of being granted free of charge, China had to repay the soviet aid in raw materials, tea, gold and Us dollars. The loan, extended at an interest rate of 1 percent, was to be given in five equal instalments, and was to be amortized over a ten-year period, starting from the end of $1954 .^{185}$

By 1957, the Soviet Union agreed to install a total of 156 complete plants. As of June 1960,130 plants with a total value of around 6 billion rubles were fully or partially

iss Alexander Eckstein. Communist China's Economic Growth and Foreign Trade: Implications for U.5. Pollcy. New York: McGraw-Hill Book Company, 1966. p. 138. 
completed and in operation. ${ }^{116}$ The data in Table 1 shows that the 156 planned projects designed by the soviets were predominately focused on the construction of chinese heavy industry, especially in the fields of machine building, coal, electric power, and non-ferrous metals.

At that time, the financial asd technical aid from the Soviet Union made a great contribution to the acceleration of China's economic recovery from the war's devastation and the pace of the implementation of China' industrialization. Li Fuchun, a Chinese leader, commented in 1959 that "without Soviet aid, our first five-year construction work would not have the present size and speed of accomplishment". 187

The Soviet Union not only provided China with material and financial support, it also dispatched thousands of soviet specialists and technicians to china to be directly involved in the construction of the chinese econcmy. It was estimated that there were total 10,800 specialists and technicians from the Soviet Union and 1,500 from other Eastern European countries in China between 1950-1960. ${ }^{188}$ In the same period, some 8000 chinese engineers and skilled workers received

166 Ibid., p. 143.

177 Calvin suey Keu Chin. A Study of Chinese Dependence Upon the soviet Union for Economic Development as a Factor in Communist China's Foreign Policy. Hong Kong: Union Research Institute, 1959. p. 75.

181 The amount of 10,800 technicians from the soviet Union to China was also claimed in the announcement of Chinese Premier zhou Enlal. See Jones., and Kevil., (complied) China and the soviet Union 1949-1984. p. 16. 
training in the Soviet Union, and more than 7,000 Chinese students were educated at Soviet universities and scientific research institutes. 189

The significance of the Soviet assistance was heightened by the fact that, except for the Soviet Union and its Communist Bloc Allies, there were no other countries that would grant china financial, industrial and technical assistance. At that time, China's isolation was the result of an unfavourable international environment, due to American led trade embargo. ${ }^{190}$ Even in the 1990s, the Chinese government still positively appraised the 1950s' Soviet contribution to China's economic reconstruction. Qian Qichen, the Chinese Foreign Minister stated:

In the fifties the Soviet Union helped china in building a whole series of industrial projects which played an important part in the rapid rehabilitation and progress of new China's national economy as well as in setting up a socialist industry. ${ }^{191}$

close Sino-Soviet economic coopsration was also reflected in the field of bilateral trade. By the mid-1950s about seventy-five percent of China's trade was with the Soviet Union and its Eastern European Bloc Allies. ${ }^{19}$ The year 1959 was a turning point in bilateral economic cooperation. During

169 A. Eckstein. pp. 168-169.

190 Ibid., P. 168 .

191 Qichen Qian. "Leaders of World Democracy: View from Beijing", International Affairs. (Moscow), August 1990, p. 23.

192 segal., sino-Soviet Relations after Mao. p. 4. 
that year, trade between the two countries exceeded US $\$ 2.0$ billion, and china replaced East Germany as the main trading partner of the Soviet Union. ${ }^{193}$ It should be pointed out that due to divergent economic interests, there were no long-term agreements between the two countries, in spite of soviet eagerness to sign such an agreement. 194

During the second period (1960-1970), with the deterioration of political relations, the sino-soviet economic contacts sharply decreased. In July 1960, Khrushchev decided to withdraw all 1,390 soviet specialists from china, and demanded that Beijing repay all debts and credits immediately. The withdrawal of soviet specialists and technicians caused China to suffer serious economic dislocation.

In 1960 , the value of sino-Soviet trade aropped to $\$ 1.7$ billion. This downward trend continued in 1961, with the volume of trade being only $\$ 900$ million that year; the lowest amount since 1952. The volume of trade in 1962 (\$750 million) was only 36 percent of the 1959's figure. ${ }^{195}$ Trade in this period was characterized by a large chinese export surplus with the soviet Union. As seen from Table 2, it was obvious

193 Philip E. Uren. "Economic Relations Among the Communist states", in Bromke, Adam. (ed.) The Communist states at the Crossroads: Between Noscow and Peking. New York: Frederick A. Praeger, 1965, P. 201.

19 For detall and good analysis see, A. Eckstein. communist china's Economic Growth and Foreign Trade: Imp ications for U.S. Policy. P. 140.

195 Uren., "Economic Relations Among the Communist states", p. 201 . 
that from 1956 the amount of Chinese exports exceeded the amount of imports from the soviet Union. In 1962, China maintained a $\$ 282.6$ million trade surplus with the soviet Union, the largest export surplus since 1950. The trade surplus reflected China's determination to clear all its debts with the Soviet Union as rapidly as possible. By 1965, all debts had been paid off. ${ }^{19}$ at the beginning of 1970, sinoSoviet trade turnover reached the nadir of its bilateral trade record. In 1970 trade was only $41.9 \mathrm{million}$ rubles (see rable 3).

rable 1. Planned projects in Cbina During the first Five-Year plan (1953-1957)

Industry

1. Heavy Industry

Iron steel

Non-ferrous Metals

Electric Power

Machine-building

Coal

oil

Chemicals
Planned No.

15

18

107

63

194

13

15

Designed No. by USSR

2. Light Industry

Food

Drugs Medical Supplies Paper

3. Others

Total Projects

Sources Sidney Kleln, The Road Divides: Economic Aspects : the SinoSoylet plipute. Hong Xong: Internatlonal studies Group, 1966, Pp. 54-55. The original cource is from Lrat Five-year Plan for pevelopment of the National Economy of the People'e Republic of China in 1953-1957. Beifing: Forelgn Languagea Pres8, 1956, PP. 55-96.

196 Ibid.. p. 202, and Harry Gelman. "Outlook for sinosoviet Relations", Problems of Communism. Vol. XXVIII, Nos. 5-6, september-December, 1979, p. 61 . 
Table 2. Bino-8oviet Trade, 1950-1964

(In millions of US dollars)

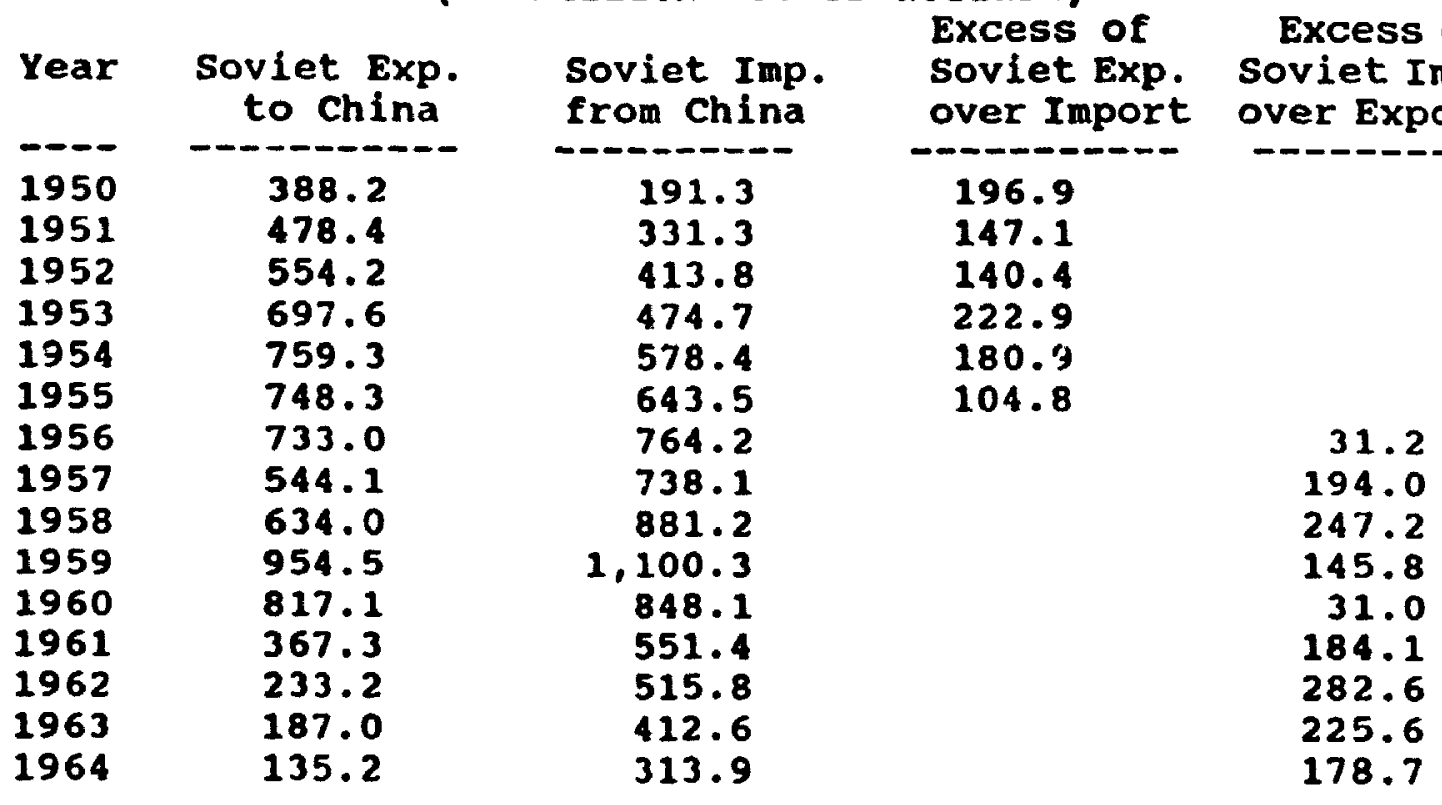

Sources:

Cited from Sidney Klein, The Road Divides: Economic Aspects of the Sino-Soviet Dispute. Hong Kong: International Studies Group, 1966, pp. 8788.

Kleln's data is from: For years 1950-1954, Marcello Caiola, "The Balance of Paymente of the USSR, 1959-60\%, Dimenglong of Sovlet Economle Power, Hearings, Jolnt Economic Committee, Congress of U.S., December 10, 11, 1962, U.S. Government Printing office, 1962, p. 156, (converted from "old roubles" at rate 1 rouble $=u s$ s 0.25 ):

For ycare 1955-61, from Dimenslong of soviet Economlc Power, pp. 738-739, For years 1962-63, data from Lar Eastern Economic Review, october 1, 1964, p. 28, and for year 1964, from Ear Eastern Economic Revlew, October 28,1965, p. 151 , (converted at rate 1 rouble=us $\$ 1.11$ ).

1965

1966

1967

1968

1969

1970

1971

1972

$19 \% 3$

1974
Table 3. soviet Trade with china, 1965-1974

(militions of rubles)

Import from PRC

$$
\begin{array}{r}
203.0 \\
128.0 \\
51.0 \\
33.0 \\
26.1 \\
19.5 \\
68.6 \\
110.4 \\
100.8 \\
105.5
\end{array}
$$

Export to PRC

172.5

157.8

45.3

53.4

25.0

22.4

70.1

100.2

100.5

108.4

Sources: John L. Scherer (ed.), USSR Facte and Pigures Annual: 1972, US: Academic Internatlonal Press, vol. 1, 1977, p. 199. These flgures are orlginally from Venshniala Torgovila, 1966-1974. 
During the third period of 1.971-1980, bilateral economic relations began to gradually revive. Concurrently, there was also a steady increase in bilateral trade. In 1974, the trade value of Soviet imports from China was 105.5 million rubles (5 times of the value trade in 1970), while soviet exports to China was 108.4 million roubles (see Table 3 ). In spite of this improvement, sino-Soviet trade remained a very minor factor in the overall foreign trade of each country.

One reason for this situation was Beijing's memory of the negative impact on the chinese economy, caused by the Kremlin's abrupt withdrawal of soviet specialists in 1960. Moreover, the Soviet economic boycott of China greatly intensified China's economic difficulties in 1960-1962, due to bad harvests and the mistaken policies of the "Great Leap Forward". With this record in mind, China did not allow the Soviet Union to reoccupy a central role in the chinese economy in order to avoid any future attempts by Moscow to use economic means for political blackmail. ${ }^{19}$

Another reason for China's reluctance to have close economic relations with the Soviet Union was a result of Chinese economic policy. Since 1972, the chinese regime, led by Premier zhou Enlai, had shifted its economic policies from close relationship with the Soviet Union to closer ties with industrialized capitalist countries. At that time, China began

61.

19 Gelman., "Outlook for Sino-Soviet Relations", p. 
to import massive amounts of equipment and technology from Japan, the United Stites ard the Western European countries. As well, China accepted long-term credits from these countries. After Mao's death in 1976, under the guidelines of the policy of "the Four Modernizations", the approach of economic engagement with the West gained a strong impetus.

During the 1970s, the amount of sino-Soviet trade was kept in rough balance and renegotiated every year. By the late 1970s, sino-Soviet two-way trade accounted for about 2 percent of the total volume of China's foreign trade, and an even smaller amount of the total volume of Soviet foreign trade. ${ }^{198}$ During this period, the soviet and chinese economies had become more competitive and less complementary than they once were. For example, in the oil sector, where china was formerly dependent on soviet petroleum assistance, by 1965 , China had not only achieved self-sufficiency in oil production, but had also become an oil exporter. Thus, it became a competitor with the soviet Union in the global petroleum export market. Moreover, both countries had become competitors in gaining Western technology. ${ }^{199}$

During the period of 1980-1984, sino-soviet economic coope:ation made dramatic progress, although at a relatively low level. The change was mainly attrihuted to the Chinese side. China wanted to widen its economic trade partners,

194 Ibid., p. 62.

199 Ibid., pp. 61-62. 
decrease imported Western technology, and desired to obtain Soviet equipment and technology (which wcre cheaper than those of Western couniries) so as to renovate plants built with the Soviet aid during the 1950s. ${ }^{200}$

However, problems in sino-soviet political relations were still conducive to creating strains in thei: economic relations. Due to political factors, especially the sinovietnamese war and the Soviet invasion of Afghanistan, bilateral trade dropped in 1980 and 1981 . With the reopening of political dialogues in 1982, bilateral trade increased, reaching US\$363 million. ${ }^{201}$ Table 4 shows that in 1980 soviet foreign trade turnover with China vas 316.6 million rubles, which was only 0.4 percent of soviet foreign trade. However, three years later, trade increased rapidly, totalling 977,8 million rubles in 1984 . During that year, China represented 0.7 percent of Soviet foreign trade, almost double the 1980 figure. Nevertheless, China's trade value with the soviet Union was fairy modest, compared with that of sino-American trade. In 1984, trade between China and the United states amounted to US\$ 6.1 billion. ${ }^{202}$

200 Gerald Segal. "Sino-Soviet Detente: the Long and winding Road", Journal of Communist st Idies. Vol.1, No.1, March 1985, p.24.

201 Loulse do Rosario. "Recovering Lost Time", Ear Eastern Economic Review. January 1, 1987, p. 46.

202 Nayan Chanda. "Superpower Triangle", Ear Eastern Economic Reylew. April 4, 1985, p. 18. 
In 1983, border trade between China and the Soviet Union was resumed. The visit by I.V. Arkhipov in December 1984 opened a new stage in sino-Soviet economic relations.

Table 4. Boviet Poreign Trade Turnover With China 1980-1984 (in million rubles)

$\begin{array}{llcr}\text { Total } & 1980 & 1984 & 1985 \\ \text { Turnover } & 316.6 & 977.8 & 1614.9 \\ \text { Export } & 169.6 & 467.9 & 780.4 \\ \text { Import } & 147.0 & 509.9 & 834.5\end{array}$

Sources: Complied from Uneshnie Elonomic':eskie Sviazi SSSR v 1985g. Moscow: Ministerstvo Vneshnoy Torgovil, 1985, p. 11; and the same title in 1986, p. 11.

Table 5. Boviet Foreign Trade, 1980-1985 (q)

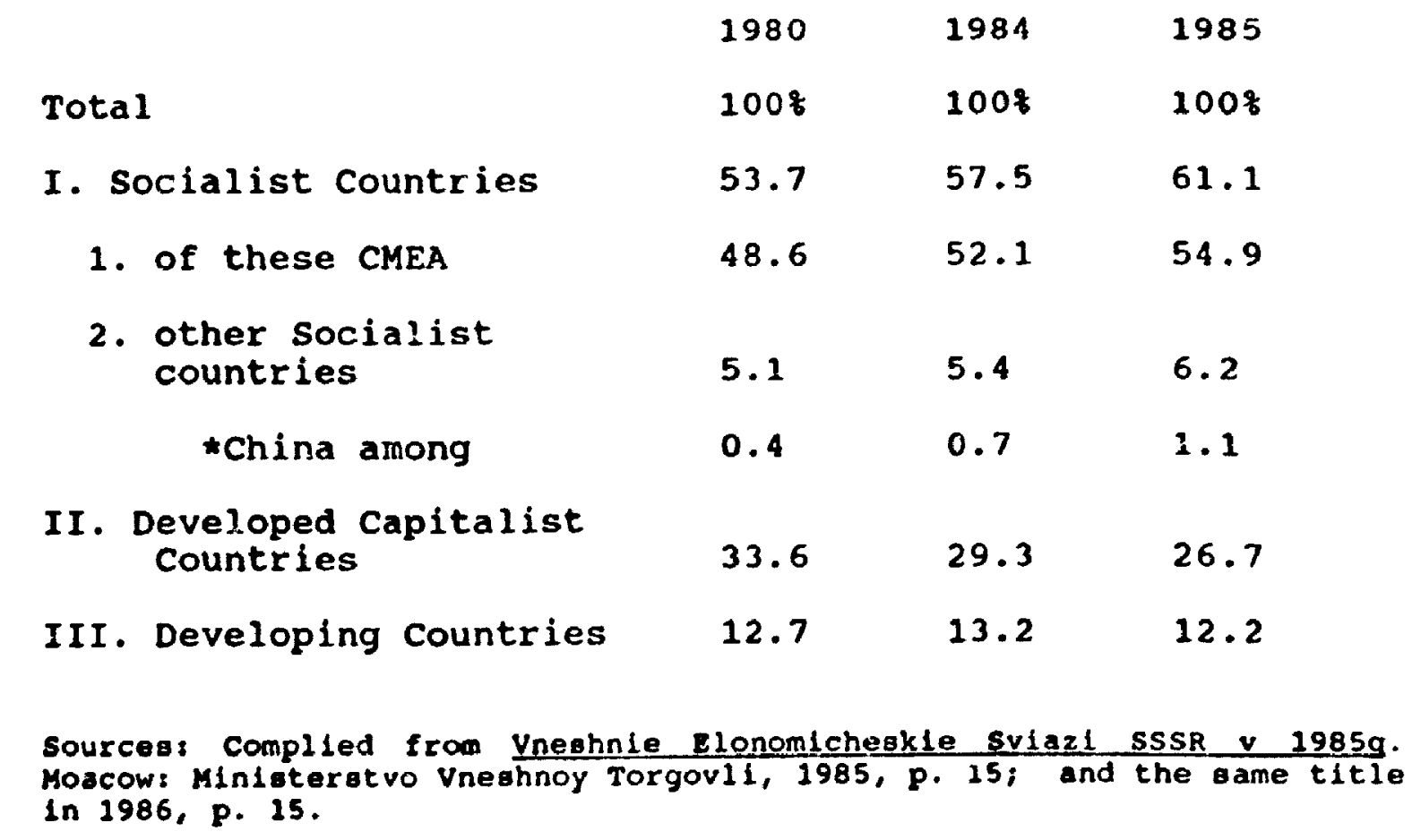




\section{A New stage of Economic Relations:}

After having briefly reviewed sino-soviet economic history, we turn now to economic relations during Gorbachev's administration.

The new sino-Soviet economic relations was first formulated in December 1984, prior to Gorbachev's accession to the post of General secretary, by the eight-day visit of Ivan v. Arkhipov to China. Arkhipov was a soviet First veputy Premier and an economic affairs specialist who headed the Soviet economic assistance program to china during the $1950 \mathrm{~s}$.

The visit provided a foundation for future high-level contacts between the two countries in the fields of economics, trade, science and technology. The visit was concluded with the signature of three agreements by Arkhipov and his Chinese counterpart Yao Yilin on December 28 . The three agreements dealt with: economic-technical cooperation in modernizing industrial enterprises built with the soviet aici in the 1950s; scientific and technical exchanges; and the establishment of a Sino-Soviet Commission on Economic, Trade, Scientific ar.d Technical cooperation. Furthermore, both sides decided to increase bilateral trade exchanges in 1985 to an overall value of 4,600 million swiss francs (about us\$ 1,750 million). During Arkhipov's visit, both sides also agreed to enter into concrete negotiations on establishment of a long-term trade agreement covering the period of china's seventh Five-Year Plan (1986-1990). The agreement was expected to be concluded 
by a visit of a Chinese deputy premier to Moscow during the next year. ${ }^{203}$

Chinese Deputy Premier Yao Yilin reciprocated Arkhipov's visit in July 1985. He met with Arkhipov in Moscow and discussed bilateral economic and trade issues. Yao's visit ended with the signature of an agreement on sconomic and technological cooperation in building and reconstructing industrial installations in china. Under this agreement, the Soviet Union would help China to build 7 new plants and reconstruct 17 existing plants in the fields of energy, transportation and other heavy industries. China would receive from the Soviets a supply of machines, equipment and transport facilities, as well as raw materials for construction. In return, China would provide the Soviet Union with agricultural products, industrial raw lüaterials and consumer goods. ${ }^{204}$ Another agreement signed during the visit concerned trade and payments for the period of 1986-1990. During that period, sino-soviet trade was expected to reach about 12 billion rubles (that is US\$ 14 billicns). It was expected that in 1990 alone, the bllateral trade would reach 3 billion rubles (i.e.

203 Mary Lee. "A Back Seat for Politics", Ear Eastern Economic Review. January 10, 1985, p. 15. and Keesing's Contemporary Archives: Record of World Events. Vol. XXXI, No. 3, 1985, p.33469.

201 Richard Nations. "A \$14 Billion Deal", Far Eastern Economtc Reytew. July 25, 1985, p. 12 . 
US\$ 3.5 billion), the planned amount. would nearly double the 1985 volume. 205

These agreements, along with those signed previously, provided a regular framework for long-term trade, and for economic, scientific and technological cooperation between the two countries based on the principles of equality and mutual benefit, and in the interests of both countries' economic progress.

The Joint Boviet-chinese Commission:

As mentioned above, the soviet-Chinese commission on Ecoromic, Trade, scientific and Technical cooperation (hereafter CETSTC) was formed in accordance with an agreement signed between the soviet and chinese Governments on 28 December 1984 . The Committee supervised the inplementation of various agreements between the two countries on economic, trade, scientific-technical cooperation, and then put forward suggestions and measures for the steady development of bilateral cooperation in these fields. According to the agreement, the committee: was co-chaired by each side's deputy premier or vice chairman.

Before Sino-Soviet normalization came about in May 1989. there were three sessions of CETSTC, held in Beijing and Moscow alternatively.

On March 14 1986, Ivan Arkhipov went to Beijing to chair the first section of the soviet-chinese commission on 
Economic, Trade, Scientific and Technical cooperation. It is worth noting that Moscow first planned to dispatch Nikolay Talyzin, a First Deputy Premier and new-appointed alternate politburo member who was close to Gorbachev. However, at the last moment, the kremlin decided to downgrade the head of the delegation, by sending 78-year-old I. Arkhipov, who was also a First Deputy Premier, but with only membership of communist Party Central Committee, thus less powerful than Talyzin. This action was seen by western diplomates as a sign from the Kremlin that "a more realistic mood was setting in over sinoSoviet relations, which had been touched with a whiff of euphoria in the past two years", a comment made in a Hong Kong newspaper. ${ }^{206}$

Chinese Vice-Premier Li Peng acted as the Chairman of the Chinese delegation to the Commission. Arkhipov was received by Chinese Premier zhao ziyang and Chinese Vice-Premier Wan Li. ${ }^{20}$ At the request of Gorbachev, Arkhipov briefed the Chinese leaders about the Soviet's economic policy adopted at the 27th CPSU Congress. During the meeting, both sides agreed to build two new railway projects. The first project. would link the Soviet Central Asian regions and China's Xinjiang Uygur Autonomous region. The second project would link the existing three railways connecting the Soviet Far East and

200 Hong Kong AFP in English, March 13, 1986, in FBISSOV-86-049, March 13, 1986, p. B1.

201 Pravda, March 22, 1986, p. 4, in FBIS-SOV-86-056, March 24, 1986, Dp. B1-B2. 
China's northeastern areas. Moreover, they also agreed to increase Dilateral shipping and to open shipping representatives' offices in Odessa and Shanghai respectively. ${ }^{200}$

Both sides had been satisfied with the constant development of trade and economic relations between the two countries in recent years. In 1984, the total bilateral trade amounted to almost 1 billion rubles, compared with 500 million rubles in $1983 .{ }^{209}$ The two-way trade volume in 1985 exceeded 1.6 billion rubles (equivalent to uS $\$ 1.9$ billion), an increase of 60 percent over the previous year and a new record in recent years. ${ }^{210}$

The first session of the CETSTC ended on March 22 with the signing of two protocols, including one concerning the exchange of engineers and technicians. The protocols were seen as a means of increasing technical assistance to those industrial plants built with the soviet aid during the 1950 s. Both sides noticed considerable potential in increasing scientific and technical cooperation, and expected to cocperate in the fields of planning, education and civil aviation. The joint commission estimated that the total value

200 Tokyo Kyodo in English, March 24, 1986, in FBIS-SOV86-056, March 24, 1986, pp. B2-B3.

209 Pravda, September 23,1986 , p. 4, in FBIS-SOV-86188, September 29, 1986, P. B1.

210 Hoscow in Mandarin to Southeast Asia, March 31, 1986, in FBIs-SOV-86-063, Apr 11 2, 1986, p. B1. 
of bllateral trade would exceed US\$ 2.3 billion in 1986.211

The second session of CETSTC began in Moscow on 12 May 1987. This time, the co-chairmen were Nikolay Talyzin, First Deputy Chairman of the USSR Council of Ministers, and Yao Yilin, Vice-Prenier of the PRC state Council. During the meetings, they examined the results of fulfilment of accords. ${ }^{212}$ In addition, an agreement on Soviet assistance to China in construction work was reached at the meeting. The commission decided to set up two permanent working groups: for cooperation in energetics, and for mutual ties and cooperation between the state planning committees of two countries.213

The third session of CETSTC opened in Beijing on June 3 , 1988. This time, the co-chairmen were Yuriy D. Maslyukov, Deputy Chairman of the USSR Council of Ministers and Chairman of the state Planning Committee (Gosplan) of the USSR, and Tian Jiyun, Deputy Premier of the State Council of the PRC. 214 Both sides were satisfied with the steady development of bilateral cooperation in economic, trade, scientific-technical and cultural fields, and the rapid growth of the border trade. However, they also noted that the potential for expanding

211 Keesing's Contemporary Archives, Vol. XXXIII, No. 4, 1987, p. 35065 .

212 Moscow TASS International service in Russian, May 12, 1987, in FBIS-SOV-87-092, p. B1.

213 Moscow TAss International service in Russian, May 13, 1987, in FBIS-SOV-87-093, May 14, 1987, p. B1.

214 Pravda, June 3, 1988, p. 5, in FBIS-SOV-88-109, June 7. 1988 , Pp. 28-29. 
economic cooperation had not been fully realized. On June 8 , 1988, the officials of both governments sigred two documents providing for the establishment of joint ventures and economic ties between ministries, departments, corporations and enterprises. ${ }^{215}$

The highlight of this session was the signing of two intergovernmental agreements. One was on the principles of the establishment and activities of joint sino-soviet enterprises. The other agreement concerned direct economic ties between Soviet republics, oblasts, ministries, dıpartments, associations, and enterprises and China's provinces, autonomous regions, cities and enterprises.

Shortly thereafter, China's Ministry of Foreign Economic Relations and Trade decided to give local governments (which covered not only the border regions, but also the interior and coastal regions) the power to engage in barter trade and sign contacts with the Soviet Union and East European countries. ${ }^{216}$ The outcome of the commission's session was that it offered great opportunities for new participants to involve in bilateral trade and economic contacts.

Torelgn Trade:

China's imports from the Soviet Union mainly consisted of raw materials such as cast iron, rolled ferrous metals, steel

215 Ibid.

216 "Sino-USSR Trade Makes Headway", Beijing Review. Vol. 31, No. 31, August 1, 1988, p. 8 . 
pipes, aluminum, carbamide, cement, and sawed timber. The Soviet Union also supplied China with industrial goods such as power units, freight and open cars, electric locomotives, metal-cutting machine tools aircraft, and spare parts for automobiles. China's exports to the USSR were included raw materials, and some chemical and machine-building products. However, agricultural products, light industrial goods and textiles were the main goods exported to the Soviet Union. 217 In 1985, the proportion of machines, equipment, and transportation products represented 31.3 percent of soviet exports to China. It was proposed by the two sides that this proportion should rise about 50 percent during the period $1986-1990 .{ }^{218}$

Bilateral trade was conducted on a barter basis, denominated for convenience in swiss francs on the basis of negotiated prices. The total value of trade between the two countries amounted to US\$ 1.9 billion in 1985. China's imports from the Soviet. Union were US\$ $940 \mathrm{million}$, and exports to the USSR were US\$ $960 \mathrm{million}$, with a favourable balance of US\$ 20 milition. 219

The volume of Sino-Soviet trade in 1985 increased by more than 60 percent as compared with 1984, and the range of traded

217 Ekonomicheskaia Gazeta, February 5, 1987, in FBISsov-87-034, February 20, 1987, p. B4.

218 Ib1d.

219 Haltao Yue. "Sino-Soviet Trade Mounts", Beiting Revlew. Vol. 29, No. 41, October 13, 1986, p. 33 . 
products also increased. ${ }^{20}$ However, the amount of sino-Soviet trade in 1985 accounted for slightly over 3 percent of China's total foreign trade, and only 30 percent of the value of China's trade with the United States. ${ }^{21}$

With the increase of sino-Soviet trade, both sides were eager to exhibit each other's products, by holding exhibitions. In accordance with a 1986 sino-Soviet agreement on the exchange of exhibitions, a trade and economic exhibition, organized by the chinese committee for the Development of International Trade, opened on July 25 of that year in Moscow. It was the first time since 1953 that a Chinese exhibition on such a large scale took place in Moscow. On the occasion of the opening of the exhibition, $\mathrm{Li}$ Peng, Vice Premier of the state council, sent a message of greetings. The fair depicted the latest chinese achievements in industry, agriculture, science, culture and art. $m$

During the 17 days of the exhibition which ended on August 10, about 300,000 Soviet visitors and more than 30 high-ranking Soviet leaders, including Chairman of the USSR Council of Ministers Ryzhkov, Deputy Chairmen of the Soviet

220 Pravda, March 22, 1986, p. 4. in CDSP. vol. XXXVIII, no. 12, April 23, 1986, p. 29.

ni China Daily. January 23, 1986, p. 1.

222 Moscow Radio Peace and Progress in Mandarin to China, August 6, 1986, in FBIS-Sov-86-152, August 7, 1986, p. B1; Investila: July 27, 1986, p. 5, in FBIS-sov-86-146, July 30, 1986, P. B1. 
Council of Ministers Talyzin and Voronin, and Risa Gorbachev visited the exhibition. ${ }^{m}$ Pravda stated:

Familiarization with the exhibits leads to the conviction that there are very big reserves and untapped potential in the development of soviet-Chinese trade and economic cooperation. ${ }^{\text {na }}$

There was no doubt that the exhibition would contribute to the further widening of bilateral trade and economic cooperation between the two nations.

on the soviet side, a similar exhibition was held in Beijing at the end of December 1986. The exhibits came from more than 20 All-Union Foreign Trade Associations, the USSR Academy of science, and various institutions and organization. 25 at the fair, the soviets displayed 3000 various exhibits, including machine tools, power engineering equipment, automobiles, ships and space equipment and modern soviet aircraft. Since the fair was held during a period of rapid expansion in bilateral economic and trade cooperation, it arouse special interest among the chinese. There were

moscow Domestic Service in Russian, August 10, 1986 , in FBIS-SOV-86-154, August 11, 1986, p. B1; Moscow Radio Peace and Progress in Mandarin to China, August 6, 1986, in FBIS-sov-86-152, August 7, 1986, p. B1.

2a Pravda, August 6,1986, p. 5 , in FBIS-SOV-86-152, August 7, 1986, P. B2.

ns Sotsiallsticheskala Industriia, December 28,1986 , p. 3. In FBIS-SOV-87-044, January 7, 1987, p. B2 . 
250,000 Chinese visitors, and a number of contracts were signed during the exhibition. 20

The implementation of the trade agreements signed by Yao and Arkhipov, as mentioned above, required the expansion of bilateral contacts at the working level, and the reestablishment of links that had been interrupted for more than 20 years. In May 1986, a delegation from the Soviet Ocean Shipping Company visited Shanghai. An agreement was signed to open an office in that city to handle the growing volume of trade between the two countries. A counterpart chinese of $f$ ice was to be set up in Odessa. ${ }^{27}$ In February 1987, the soviet Ministry of Maritime fleet set up a permanent office in Shanghai. Shortly thereafter, a similar of ice was set up in Odessa by the China Ocean Shipping Company. These two offices were to provide shipping services between two countries. ${ }^{20}$

In 1987, Sino-Soviet trade declined somewhat ir. comparison with 1986. The reductions was partly due to the failure of the soviets to provide some of the products demanded by the chinese, especially machines and equipment. At

226 Sovetskaia Rossila, December $30,1986, p .5$, in FBIS-SOV-87-002, January 5, 1987, p. B2.

$m$ Moscow in Mandarin to China, February 6, 1987, in FBIS-SOV-87-028, February 11, 1987, P. B1.

228 Moscow in Mandarin to China, February 6, 1987, in FBIS-SOV-89-028, February 11, 1987, p. B1. 
the same time, the decrease in trade was affected by the fall of prices on the world market. ${ }^{20}$

on 15 July 1988, Beijing and Moscow signed a new accord, under which Chinese and Soviet citizens would no longer need visas to travel to each other's countries on business, if they could provide valid travel certificates. The accord came into force on August 13 of that same year. ${ }^{230}$

sino-Soviet trade reached US\$ 3.23 billion in 1988 , which was more than ten-fold increase over 1981. However, the Soviet Union still ranked fifth among China's trading partners, and accounted for only 3.1 percent of China's total foreign trade. Meanwhile, China accounted for only 1.4 percent of the Soviet's total trade (see Table 7). ${ }^{231}$

In December 1988, an intergovernmental agreement was concluded, under which the Soviet Union would supply China with credit for rails, commercial timber and equipment to construct the railway linking China's Xinjiang region to the Turkestan-siberian Railway at Alma Ata in the soviet Kazakhstan. The Chinese side had paid great attention toward the reestablishment of this main railway line. As a transAsian railway along the ancient "Great silk Route", tris

229 Izvestifa, January 23, 1988, p. 1, in FBIS-SOV-88019, January 29, 1988, p. 15.

2n "Sino-USSR Trade Makes Headway", Beijing Review. August 1, 1988 , p. 8 .

231 Robert Delfs. "One stage, Two Plays: Deng's Position Undercut at Moment of History", Far Eastern Economic Review. May 25, 1989, p. 14. 
railroad would be the shortest rail route from Europe to China and Hongkong. Thus, it served as "a window on Europe". ${ }^{232}$ The momentous economic reforms in both countries stimulated cooperation in economic planning in January 1988 . In that year, the first session of the permanent working group on mutual ties and cooperation between the two countries' state committees, which was under the auspices of the sovietChinese Commission on Economic, Trade, Science and Technical Cooperation was held in Beijing. The Soviet delegation was led by S.A Sitaryan, First Deputy Chairman of the USSR Gosplan. Both sides discussed a broad range of issues on the practical realities of implementing economic reform and economic development in the two countries. ${ }^{23}$

¿32 E. Matskevich. "'Great Rail Route' Opens", Izvestiia, September 12, 1990, p. 1. Text is translated in CDSP. Vol. V'LII, No. 37, October 17, 1990, p. 22

233 Izvestila, January $20,2988, p, 4$, in FBIS-SOV-88103, January 21, 1988, pp. 15-16. 
Table 6. 8oviet Foreign Trade Turnover with China 1985-1990 (in miliion rubles)

$\begin{array}{lrrrccc}\text { Total } & 1935 & 1986 & 1987 & 1988 & 1989 & 1990 \\ \text { Turnover } & 1514.9 & 1822.0 & 1474.9 & 1850.1 & 2412.0 & 3038.0 \\ \text { Export } & 780.4 & 910.3 & 724.3 & 1005.2 & 1328.5 & 1377.7 \\ \text { Import } & 834.5 & 911.7 & 750.6 & 844.9 & 1083.5 & 1660.3\end{array}$

Sources: Complied from Vneshnte Elonomicheskie Sviazl SSSR $v$ 1985a. Moscow: Ministeratvo Vneshnoy Torgovil, 1985, p. 11; and the same title In 1986 in p. 11, 1987 in p. 11,1988 in p.11, 1989 in p.12 and 1990 in p.12.

Table 7. Boviet Foreign Trade, 1986-1990 (t)

\begin{tabular}{|c|c|c|c|c|c|}
\hline & 1986 & 1987 & 1988 & 1989 & 1990 \\
\hline Total & 1008 & 1008 & .008 & $100 \%$ & 1008 \\
\hline I. Socialist countries & 66.8 & 67.0 & 65.3 & 61.7 & N.A. \\
\hline 1. of these CMEA & 61.1 & $6: .7$ & 59.7 & 55.8 & N.A. \\
\hline $\begin{array}{l}\text { 2. other Socialist } \\
\text { countries }\end{array}$ & 5.7 & 5.3 & 5.6 & 5.9 & A.A. \\
\hline *China among & 1.4 & 1.1 & 1.4 & 1.7 & 2.3 \\
\hline $\begin{array}{l}\text { II. Developed Capitalist } \\
\text { Countries }\end{array}$ & $22 \cdot 2$ & 21.8 & 23.4 & 26.2 & N.A. \\
\hline III. Developing Countries & 11.0 & 11.2 & 11.3 & 12.1 & N.A. \\
\hline
\end{tabular}


Construction and rransformation of Industrial Projets:

The renovation and construction of China's industrial projects with the help of the USSR played a major role in restoring and developing sino-soviet economic relations in the 1980s. Those projects included 7 new industrial enterprises and renovation of 17 industrial enterprises such as the Baotou Iron and steel company, the Wuhan Iron and Steel Company, and Luoyang Ballbearing Plant, the Jiamusi Paper Pulp Mill and the Harbin Flax Factory. ${ }^{234}$ These were still state-owned large enterprises.

The remodelling of China's power industry occupied an important place in the projects of intergovernment cooperation. While Yao yiling was in Moscow in 1985, a protocol was signed, which stated that the suriet side would provide China with a new generator units (with power capacity of 500 and 800 megawatts) for the construction of three thermal power plants. ${ }^{235}$ All three of these plants are located in north-eastern china, where abundant sources of coal could be accessed as fuel. Soviet experts were also responsible for designing the Yumen thermal power station.

It was reported in June 1987 by a soviet source that the design of the Jixian thermopower plant had been completed and that of the Yumen thermopower plant was almost finished. For

234 Haitao Yue. "Sino-Soviet Trade Booms", Beijing

Review. Vol. 32, No. 5, January 30, 1989, p. 29.

23s Moscow in Maridarin to China, March 3, 1987, in FBIssov-87-043, March 5, 1987, pp. B2-83. 
each of these two power plants, it was proposed that the Soviet Union supply china with complete units of modern equipment, including two 500,000 kilowatt generators. ${ }^{236}$

Soviet assistance in renovating these projects would ease the energy shortage in China. During the first stage of the project, both the Jixian and Yumen power plants would be capable of generating 1 million kilowatts respectively. In December 1987, a delegation from the Northeast Power Design Academy of China's Ministry of Water Conservancy and Power visited the Soviet Union, where they signed a protocol with the soviet Industrial Technology Export Company on coordinating the design of the two 800,000 kilowatt generating units for China' suidong Power station. ${ }^{237}$

Border rrade:

One of the notable features in sino-soviet economic relations in the 1980 s was the reopening of border trade. Sino-Soviet border tradf can be traced back to 1958, when the consumer unions of the Khabarovsk Territories and the trade companies of the Chinese Province of Heilongjiang exchanged consumer items and goods for industry and agriculture. Two years later, border trade was expanded to areas between the

236 Moscow in Mandarin to China, March 31987 , in FBIssov-87-043, March 5, 1987, pp. B2-B3; Moscow in Mandarin to Southeast Asia, May 30, 1987, in FBIS-SOV-87-105, June 2, 1987, P. B3; and Moscow in Mandarin to China, June 19, 1987, in FBIS-SOV-87-124, June 29, 1987, pp. B1-B2.

207 Moscow International Service in Mandarin, December 9, 1987, In FBIS-SOV-87-237, December 10, 87, p. 39. 
Chita Region and the Hailar District of the Autononous Region of Inner Mongolla, and between the Kazaich, Kirghiz and Tadjik Regions and the Xinjiang-Uygur Autonomous Region. ${ }^{238}$ The overall volume of border trade in 1960-1968 was 24 million rubles, reaching its highest point at $5.8 \mathrm{million}$ rubles in 1960. However, due to the deterioration of bilateral relationship and the dispute on trade payment, border trade ceased in 1968.239

After the suspension of trade for more than a decade, USSR-PRC border trade resumed in 1983, between the Khabarovsk and Maritime krays, Amur and Chita oblasts on the Soviet side, and Heilongjiang Province, the Inner Mongolia Autonomous Region on the Chinese side. Bordar trade was coordinated by the All-Union Foreign Trade Association "Dalintorg" of the USSR, and the Trade Company of the Heilongjiang Province and the Trade Company of the Autonomous Region of Inner Mongolia. The Soviet's Grodekovo and Zabaikalsk (names of place) and Chinese Suifenhe and Manchuria were chosen as the transhipment points for transport of foreign trade freight between the two countries. 200

238 Anatoli Kiryanov. "The USSR and the PRC: Border Area Trade", International Affairs. (Moscow), October 1986, p. 154.

239 Ibid. and Ekonomicheskaia Gazeta, November 13 , 1986, p. 23, in FBIS-SOV-86-230, December 1, 1986, p. B1. Trade"

240 Kiryanov., "The USSR and the PRC: Border Area p. 154 . 
sino-Soviet border trade was a barter trade, that was, the exchange of equivalent amount of goods. At first, the volume of border trade was relatively marginal, reaching 6.1 million rubles in 1983 . However, thanks to the rapid development of overall trade ties between the Soviet Union and China, border trade increased rapidly. In 1984, border trade amounted to 15.2 million rubles, a 2.5 increase over the previous year. In 1985, trade reached 25.3 million rubles, a more than 1.5 increase compared to $1984 .^{211}$

From 1986 onward, border trade extended to the northwestern border regions. It was conducted between the Soviet Central Asian republics, Kazakhstan, and regions and oblasts of the RSFSR, and the Xinjiang-Uygur Autonomous Region in China, via the border points of Khorgos and Turugart. ${ }^{242}$ Border trade in this region was conducted through the AllUnion Foreign Trade Association "Vostokintorg" and the Local Trade Import-Export Company of the Xinjiang-Jygur Autonomous Region respectively. ${ }^{243}$ The total trade value between

24 Ekonomicheskala Gazeta, November 13, 1986, p. 23, in FBIS-sov-86-230, December 1, 1986, p. B1.

242 Sotslalisticheskaia Industriia, June 13,1986, p. 3, in FBIS-SOV-86-120, June 23, 1986, p. B3. Trade",

243 Kiryanov., "The USSR and the PRC: Border Area p. 155 . 
Kazakstan and Xinjiang-Uygur Autonomous Region reached 16 million Swiss francs in 1986-1987.244

Due to the increase in border trade, at the beginning of 1986, a new trade firm called "Dalprigrap" was set up in the Soviet Far Eastern city of Nakhodka. This new, specialized company was created within the system of the All-Union Foreign Trade Association "Dalintorg". 245

The increase in trade, and the diverse range of goods, demanded increased transportation. After a long interruption, river transportation between the soviet Union and China resumed. In 1985, Soviet and chinese negotiators discussed the idea of using the soviet port of Blagoveshchensk and the Chinese port of Heihe for river shipments. The negotiators wanted this scheme to begin in $1986 . .^{240}$ An agreement signed in April of 1986 stipulated that the Amur and Heilongjiang river shipping fleets could use the soviet Leninskoye port and China's Tongjiang port for transporting goods to one another. ${ }^{247}$

The establishment of a special trade company and the resumption of river traffic had greatly promoted the increase

Moscow International Service in Mandarin, January 17, 1989, in FBIS-SOV-89-013, January 23, 1989, p. 29.

24s Moscow TRUD in Russian, February 8, 1986, p.3, in FBIS-SOV-86-028, February 11, 1986, p. B1.

246 Moscow in Mandarin to China, February 6, 1987, in FBIS-SOV-89-028, February 11, 1987, p. B1.

207 Moscow Domestic Service in Russian, August 15, 1986, in FBIS-SOV-86-158, August 15, 1986, p. B1. 
of border trade. In 1586, the total volume of border trade between the soviet Far East and China's northeast region reached 28 million rubles. In 1987 , even though the amount of bilateral trade decreased, as mentioned above, the value of the border trade was double the amount of the previous year, reaching 65.4 million rubles. ${ }^{248}$ It was estimated that border trade in the provinces of Heilongjiang, Inner Mongolia and Xinjiang had amounted to us $\$ 330$ million in 1986 , which was about 16 percent of sino-soviet overall trade. ${ }^{249}$

During 1988, there were bright prospects for broadening border trade. As mentioned before, an agreement was signed in 1988 that allowed organizations and administrative units at all levels in the soviet Union and china to take part in border trade. This was a change from the past, when only areas adjacent to the border were allowed to trade. At the beginning of 1988, China's Jilin Province joined border trade activities, when the Export-Import Company of Jilin Province signed a contract on commodity exchanges with representatives from the "Dalintorg" All-Union Association.2s0 shortly afterwards, in June 1988, Liaoning Province also began to engage in border trade. An economic delegation from Liaoning

248 Moscow Radio Peace and Progress in Mandarin to AsiaPacific Reglon, April 15, 1988, in FBIS-SOV-88-077, April 21,1988 , p. 18 .

249 Rosario., "Recovering Lost Time", p. 47.

250 Ekonomicheskala Gazeta, January 21, 1988, p. 20, in FBIS-SOV-88-021, February 2, 1988, p. 30 . 
Province visited the Balkal region, and signed a document with the RSFSR Ministry of Foreign Affairs to develop trade, economic, scientific and technical cooperation. Moreover, the visitors from Iiaoning suggested a plan to allow direct trade and economic cooperation between Liaoning and the chita region, and the Amur Oblast. 251

In April 1988, at the Seventh National People's Congress, Hou Jie, Governor of Heilonjiang Province declared that the Chinese state council had granted Heilongjiang the right to make decisions not only concerning border trade, but also on establishment of joint sino-soviet projects in the border area and on modernization of factories and plants. ${ }^{252}$ Thus, besides the three already designated trade centres (i.e. Suifenhe, Heihe and Tongjiang), another six towns and counties in Heilongjiang Province (Mishan, Hulin, Raohe, Luobei, Jiayin and Mohe) were authorized to engage in sino-Soviet border trade. ${ }^{253}$

In 1988, border relations obtained a new form of cooperation - joint ventures. The soviet Far East had an enduring problem of labour shortage, while China's north-

251 Moscow International Service in Mandarin, June 12 , 1988, and Moscow World Service in English, June 14, i988, both in FBIS-SOV-88-115, June 15, 1988, p. 20.

232 Moscow TASS in English, April 12, 1988, in FBIS-SOV88-071, April 13, 1988, p. 20.

253 Moscow TASS International Service in Russian, May 14, 1988, In FBIS-SOV-88-094, May 16, 1988, p. 15. 
eastern provinces had a surplus of labour. Hence, jointventure cooperation was beneficial for both sides.

The exrhange of labour could be seen as another form of barter trade. Under joint-venture arrangements, chinese workers were sent to work in the labour-short soviet Far East and siberia in exchange for soviet goods such as timber, steel and fertiliser. By 1988, there were more than 8,000 Chinese technicians and workers ir. the Soviet Union, working in agriculture, forestry, construction and industry. ${ }^{254}$ While the Soviets were generally positive concerning the employment of Chinese workers in soviet plants, they complained the behaviour of some unqualified chinese workers. For instance, in the Volograd Tractor Plant, a plant manager complained that 40 percent of the 640 contracted Chinese workers at the plant did not go to work at all. Instead, they sold goods that they brought over from china, there-by violating the rules of Soviet trade. 255

The Advantages of 8 ino-soviet Economic Cooperation:

Given the geographic proximity and similar economic structures, China and the Soviet Union were naturally trading partners. In the $1980 \mathrm{~s}$, sino-soviet economic relations were more complementary than competitive. There were several points

234 Yu Shcherbinin. "Well, Well!: Imported skirkers", Pravda, August 21,1990, p. 6 . Text is translated in CDSP. Vol. XLII, No. 34, September 26, 1990, p. 25.

$25 s$ Ibid. 
that both China and the soviet Union could use to their advantage in their bllateral economic cooperation.

First: The Chinese economic reforms since 1978 had produced considerable surpluses of food products and consumer goods, which were needed in the Soviet Union, especially in the Soviet Far East. Since some Chinese products were not competitive enough for the international market, due to low quality. The consumer poor soviet market provided a good opportunity to sell these goods. Meanwhile, Soviet raw materials, such as steel and timber, were badly needed in China.

Second: In industrial technology, the Soviet Union could help upgrade Chinese plants built during the 1950s, such as Changchun Automobile Factory and the Wuhan Iron and steel Company, which were the largest enterprises in China. Soviet equipment and machinery were cheaper and at a medium-level of technology, compared with those from Western countries. By importing equipment and machinery from the Soviet Union, China could save foreign exchange hard currency, and at the same time maintain a healthy counter-balance to the economic tilt towards the West.

Third: Border trade could be economically advantageous for both sides. It would promote the acceleration of the socieconomic development in the Soviet Far East and the northeast and northwest areas in China, and would improve the living standards of peoples in the both countries. Moreover, for the 
Soviet Far East, border trade with china would shorten the delivery time for goods and reduce imports of similar products from the European regions of the USSR, thereby reducing unjustifiable transport costs. China was also very interested in deliveries from the soviet union of mineral fertilizers, building materials and industrially manufactured products which were available in the neighbouring soviet territory. Problose Exiating in sino-8oviet Bcononio Cooperation:

There were several factors constraining the growth of bilateral economic relations. First: Compared with China's decentralized trade system, the relatively slow pace of soviet economic reform had held back sino-soviet economic cooperation. As the Soviets still planned their foreign trade years in advance, they were not able to respond as quickly as the Chinese would like, in terms of shifting the commodity composition of trade. ${ }^{256}$ The Chinese also complained about the inflexibility of soviet business methods.

Second: For the USSR, a large part of sino-Soviet bilateral trade was motivated by its needs in the Far East and siberian regions. In these areas, the population was fairly small, and the pace of economic growth was far behind the

256 Nicholas Lardy. "Sino-Soviet Economic Relations: Prospects and Implications for U.S. Policy", sino-Soviet Relations After the summit. (A Workshop sponsored by the Senate Foreign Relations Committee and the Congressional Research Service, May 15, 1989), Washington, D.C.: U.S. Government Printing office, February, 1990. p. 112. 
already dismally low overall soviet economic performance. Hence, China was basically trading with a poor partner. 257

Third: Inadequate infrastructure hampered the expansion of bilateral trade. The capacity on the rallways connecting the sino-soviet border had been saturated. Only three railways: at suifenhe (southeast Heilongjiang), Manchuria (northwest Inner Mongolia) and Erenhot (north Inner Mongolia) were connected to the Trans-siberian Railway. In xinjiang Province, its capital Urumgi was the northernmost railway depot, and was hundreds of kilometres away from the sinosoviet border. This transportation problem could partially be solved by extending the railway connecting Urumgi with AlmaAta, and by opening up direct shipping between vladivostok and various Chinese ports.

Fourth: The trade management bureaucracies existing in both zountries hampered the cevelopment of bilateral trade. For the Soviet Central Asian Republics, trade agreements with China had to be approved by the All-Union Eastern Foreign Trade Company in Moscow. Often negotiations would take a long time and end without any results. After 1988 , the governments of the Soviet Central Asian Republics set up their own special foreign trade organizations which were authorized to trade directly with Xinjiang. ${ }^{258}$ In China, most trade problems came

\section{Ibjd.}

256 Moscow International Service in Mandarin, January 17, 1989, in FBIS-SOV-89-013, January 23, 1989, p. 29. 
from insuffisient funds, a lack of the necessary material resources, and the trade management bureaucracy. ${ }^{259}$

Moreover, high inflation rates and the unstable economies and politics of the USSR also discouraged the Chinese from expanding their business with the Soviets. ${ }^{260}$ As a Chinese economic specialist Guocang Huan pointed out: laws and regulations relating to foreign investment on both sides were not enough to alleviate the high investment risks in both countries. 201

Conclusion:

In the 1980s, even though the soviet Union occupied a small proportion of China's overall foreign trade, and could not compare with the United states and Japan, it had become China's fastest growing trade partner. Within this decade, sino-soviet trade had increased more than 10 fold.

It is obvious that sino-soviet economic relations had moved ahead of their political relations. Sino-soviet economic relations had developed long before the Soviet Union began to take steps to meet the three obstacles to better political relations put forward by China. The expansion of foreign trade and economic cooperation was based mainly on each other's

259 "Sino-USSR Trade Makes Headway", Beijing Review. August 1, 1988, p. 8. and John Tedstrom. "Soviet Trade with China", Radio Free Europe, (RL 210/88), May 17, 1988, p. 2 .

260 Guocang Huan. "The New Relationship with the Former Soviet Union", Current History. Vol. 91, No. 566, September 1991, p. 255.

261 Ibid. 
economic needs. Both China and the Soviet Union were receiving goods for which they had high demand.

Border trade had made a significant contributicn to speeding up the socio-economic development of the soviet Far East and northeastern and northwestern region of China. The border contacts had greatly improved sino-soviet goodneighbour relations, which was an important factor in the general policy for all-around normalization of bilateral relations. 


\section{CHAPTER FOUR}

The 1989 Beifing Sumit signified the ending of the abnormal state and the opening of a new stage in the relations between the two socialist countries. Since then, many events had taken place in world politics, among them the Tiananmen Square's Event on June Fourth 1989 in China, the collapse of the communist regimes in the Eastern Europe, and the rapid political change within the Soviet Union. All of these events had an impact on Sino-Soviet bilateral relations.

The purpose of this chapter is to survey sino-soviet relations from the 1989 Beijing Sunmit until the collapse of the Soviet Union. First, it will examine Moscow's reaction to the Tiananmen Square's Event, Second, it will look at how the changes in Eastern Europe had affected Sino-Soviet relations. Third, it will describe the actual cooperation between china and the Soviet Union in the fields of political and military relations. Finally, it will review the economic relationship between the two sides.

Boviet Reaction to the Tiananmen square's Event:

The Soviet responses to the Tiananmen Square's Event were on tio different levels: the official and the unofficial.

On the official level, the Kremlin's approach to the incident was to avoid direct comment on this prodemocratic movement. The Cungress of People's Deputies of the USSR adopted a caut,uus approach, by choosing a middle way between the open criticism from western countries and some Eastern 
European countrles such as Hungary and Poland, and the open support from North Korea and Romania. ${ }^{262}$ In June 1989 in Bonn, it was reported that Gorbachev indirectly criticlzed Beijing's crackdown on unarmed students in Tiananmen Square. He said that he would choose a nonviolent solution if a similar situation happened in Moscow. ${ }^{263}$ However, this statement was concealed by his official report to the supreme soviet which Gorbachev made in August of the same year. Referring to the Tiananmen square's Event, Gorbachev pointed out:

The process of change in china is a world phenomenon. Naturally, we wish the Chinese people success along the road of reform and the road they have chosen. However, it is inevitable that painful phenomena and conflicts will appear along the road. 20 t

The legal foundations of sino-soviet relations, as formed in the communique in May 1989, were based on "the five principles of peaceful co-existence", including one of noninterference in each other's internal affairs. Thus, the Soviets emphasized non-interference in china's internal affairs, and hoped that the Chinese would stabilize the situation. It was obvious that the purpose of the official Soviet reaction was to preserve and strengthen the

262 Dieter Heinzig. "The Soviet Union and China: Headed roward a New Conflict?" Aussen politik. Vol. 41, No. 3, 1990 , p. 258

263 Guocang Huan. "The Dynamics of sino-Soviet Relations", The Washington Quarterly. Vol. 14, No. 2, Spring 1991, p. 143 .

26 Moscow International Service in Mandarin, August 2, 1989, in FBIS-SOV-89-149, August 4, 1989, p. 10. 
normalization of bllateral relations recently finalized. Moreover, some Soviet experts speculated that the Soviet official approach to the Tiananmen Square's Event was also based on a consideration of reciprocal relations. Previous to this, the chinese government treated tragic incidents in the Georgian city of Tbilisi with great caution. ${ }^{205}$

However, on the unofficial level, the reaction to the June Fourth Event was very critical. When the Chinese army violently suppressed the students in Tiananmen Square, Soviet democrats held protests in front of the Chinese Embassy and consulates. Boris Yeltsin, the leading Soviet radical at that time and the ousted chief of Moscow Communist Party, said that "it was a crime against their own people, like in Tbilisi".206

After the June Fourth democracy movement, international assistance to china's modernization seriously declined. From June 1989 to October 1990, most nations of the Organization for Economic Cooperation and Development (OECD) placed economic sanctions on loans and technology transfers to China. ${ }^{267}$ In such circumstances, China turned to the soviet Union, the Eastern European countries and the third world as

205 Sergey Goncharov. "After Tiananmen Soviet sinologist on the Result of Recent Events in Beijing," Moscow News, No. 28, July 9, 89, p. 6. in FBIS-SOV-89-137, July 19, 89, p. 18 .

266 Paris AFP in English, June 5, 1989, in FBIS-SOV-89106 , June 5, 1989, p. 11. The incident of April 91989 in Tbilisi, the Georgian capital, caused 20 deaths.

261 Guocang Huan. "The Dynamics of sino-Soviet Relations", Spring 1991, p. 147. 
alternative of external partners, forelgn markets and cultural contacts.

When Jiang Zemin was elected General secretary of the Central Committee of the CCP, Gorbachev immediately sent him a massage of congratulations and expressed hope that bilateral relations would be developed in a spirit of friendship and neighbourly cooperation. ${ }^{268}$ A Soviet delegation from the Ministry of Fisheries led by its Minister Milolay Kotlyar, paid a visit to China on July 19 , even though several arranged visits from the West were cancelled. ${ }^{269}$

The Changes in Eastern Europe and Its Impact on China:

The political transformation in Eastern European countries strained sino-Soviet relations. The collapse of communism in Eastern Europe, the ousting of the communist leader of East Germany Erich Honecker in October 1989, and the execution of Romanian leader Nikolai Ceauses'u and his wife shocked the chinese regime. Beijing was very concerned about the possible impact of these developments on Chinese internal politics.

Chinese leaders held Gorbachev, if not fully responsible, at least partially to blame for the ruin of communism in Eastern Europe. Internally, Beijing criticized violations of the principles of Marxism-Leninism by these countries and

\footnotetext{
260 Moscow World Service in English, June 27, 1989, in FBIS-SOV-89-123, June 28, 1989, p. 9 .

269 Moscow TASs in English, July 19, 1989, in FBIS-SOV$89-138$, p. 22 .
} 
accused Gorbachev of being the cause of Eastern Europe's dramatic unravelling. ${ }^{270}$ It was reported that Deng xiaoping had privately stated that Gorbachev had worsened the situation in Eastern Europe. ${ }^{271}$ During the period of December 1989 to January 1990, at internal party meetings, Chinese leaders such as Jiang Zemin had bitterly accused Gorbachev of betraying socialism and warned of a "danger from the north". 2

The democracy movements in Eastern Europe had politically and psychologically impacted on chinese society in general and the political opposition in particular. The ideas and experiences in Eastern Europe had provided Chinese democrats with encouraging examples. As a result, the chinese democracy movement was continuing under ground. The active democracy movements outside china presented a challenge to the legitimacy of the chinese regime. The Romanian revolution had particularly frightened the chinese leadership. Following the Romanian revolution, new armed police units were soon organized. Meanwhile, in south china, jaming of foreign radio stations was resumed. ${ }^{m}$

270 Samuel Kim. "Chinese Foreign Policy After Tiananmen", Current History. Vol. 89, No. 549, September $1990, p 281$.

27 Heinzig., p. 260 .

$2 m$ Ibid., p. 261 .

273 Heinzig., p. 260, and G. Huan. "The Dynamics of sino-Soviet Relations", Spring 1991, p. 150. 
However, externally, the chinese government avoided any public criticism of the refection of communism in Eastern Europe, by stating its principle of non-interference in the internal affairs of other countries. ${ }^{274}$ when the soviet union abandoned its Communist Party's monopoly during the plenum of the CPSU Central Committee held in February 1990, a spokesman for the Chinese Foreign Minister declared that the abandonment of the CPSU's leading role was merely an internal Soviet affair and had no affect on mutu. relations. He stated that the Communist Party of China would still maintain its leading role in china. ${ }^{275}$

on the Soviet side, facing its own political and economic problems, Moscow refrained from any public criticism of china. When Igor Rogachov, Vice Soviet Foreign Minister, was visiting China in January 1990, he tried to play down the strain in sino-Soviet relations. re said that "ideological differences could be even between good neighbours". ${ }^{n 6}$ Thus, both Beijing and Moscow managed to ive the public the impression that the sino-Soviet relations were still basically harmonious.

Actual Process in Bilateral Relations:

Even though political-ideological differences between Beijing and Moscow existed, unlike the 1960s and the 1970s,

274 Kim., p. 281 .

ns Heinzig., pp. 259-260.

276 Moscow TASs in English, January 12, 1990, in FBISSOV-90-010, January 16, 1990, p. 25. 
they now had little impact on the practical contacts and cooperation between the two countries.m In the 1950s, the period of harmony which China and the Soviet Union had shared, the two sides believed that, since they shared the same ideology, they must have absolutely identical views on every issue. ${ }^{27}$ This dogmatism caused the split on sino-soviet relations later on.

However after the 1989 Summit, Sino-Soviet relations were based on "the five principles of peaceful coexistence", under which both sides recognized each others' independence and noninterference in each other's internal affairs. This new type of relationship prevented a severance of relations over the different politics and ideologies in the two countries. Moreover, after the Beijing Summit, contacts between the two countries were increasing. From June to December 1989, more than 100 delegatjons visited each other at deputy minister level or higher. ${ }^{279}$

One feature of sino-Soviet interparty relations after the 1989 Summit was that they resumed and developed on a new basis

\footnotetext{
$2 m$ Heinzig., p. 264 .

278 Moscow in Mandarin to Southeast Asia, September 16, 1989, in FBIS-SOV-89-180, September 19, 1989, p. 18.

27 Sophie Quinn-Judge. "Pragmatic Partners: Li Peng goes to Moscow for Military and Trade Talks", Far Eastern Economic Review. April 26, 1990, p. 12.
} 
of separation from interstate relations. This feature was quite different from relations in the $19508 .^{220}$

Interparty contacts and exchanges reached an important, new level. After a gap of almost 25 years, a party delegation of the CCP, led by zhu Llang, chief of International Liaison Department of the chinese Central Committee, came to Moscow in September 1989. ${ }^{211}$ A guideline for interparty contacts between 1989-1990 was agreed on. An invitation was conveyed from Gorbachev to Jiang zemin, the new appointed General Secretary of the CCP, to visit Moscow at a convenient time. A CPSU Central Committee delegation headed by Falin, Chairman of the International Policy Commission, visited China at the end of 1989.202 Vladimir Ivashko, Deputy General Secretary of the CPSU Central committee, made a five-day visit to china in February 1991. He was met by Jiang Zemin and Qiao Shi, a member of the starding Committee of the Politburo of the CCP Central committee. The two sides discussed the role and activities of the communist party in the economic, social and political reforms in their countries. ${ }^{283}$

280 Moscow Domestic Service in Russian, June 2, 1989, in FBIS-SOV-89-106, June 5, 1989, p. 17 .

281 Moscow in Mandarin to Southeast Asia, September 16, 1989, in FBIS-SOV-89-180, September 19, p. 18.

202 Beijing Xiuhua in English, December 28, 1989, in FBIS-SOV-89-249, December 29, 1989, p. 7 .

203 Moscow TASS International Service in Russian, February 26, 1991, and Pravda, February 28, 1991, p. 4; both in FBIS-SOV-91-041, March 1, pp. 6-7. 
Four moniths after the 1989 sumit, an important step was taken in the area of interparliamentary contacts. A Supreme Soviet delegation led by A. I. Lukyanov, First Deputy Chalrman of the USSR Supreme Soviet visited China in September $1989 .{ }^{24}$ Both sides discussed a wide range of questions concerning developing legislation, planning and financial questions, and relations between supreme representative organs and local organs of people's representatives. They agreed that there was no single, uniform pattern for building socialism. ${ }^{2 a s}$ Lykyanov's visit was hailed by Izvestiia as "a step forward" in sino-Soviet relations. ${ }^{266}$ As a return visit, a delegation from the Chinese National People's Congress, led by Peng Chong, Vice Chairman of the NPC standing committee, came to the Soviet Union in July $1990 . .^{2 m}$

At the same time, contacts and exchanges among social organizations had increased considerably. An All-China Women's Federation delegation led by it Chairperson Chen Muhua

24 Moscow International Service in Mandarin, September 12, 1989, in FBIS-SOV-89-175, September 12, 1989, p. 15.

285 Izvestiia, September 22,1989, p. 8. in FLIS-SOV-89185. September 26, 1989, pp. 9-11. and Moscow International Service in Mandarin, September 17, 1989, in FBIS-SOV-89-179, September 18, 1989, p. 24.

246 Izvestila, september 22, 1989, p. 8. in FBIS-SOV-89185, September 26, 1989, p. 10.

287 Moscow International Service in Mandarin, July 20, 1990, in FBIS-SOV-90-142, p. 10. 
visited the Soviet Union in August 1989.24 In October 1989, as the result of the visit to China by $v$. Mironenko, First Secretary of the All-Union Lenin Communist Youth League, ties between the two communist youth leagues were normalized. 219

The distinctive feature of the contacts and meetings at various levels was that both sides expressed an interest in a mutual exchange of experience in implementing reforms in the theory and practices of renewing socialism. It is worth noting that a new type of dialogue had developed that excluded any kind of imposition of one's own views on the other.

In terms of border settlement, talks on the military and border issues were increasing. The fourth round of border talks was held in Beijing in October 1989. Rogachev, Soviet Deputy Foreign Minister, attended the taiks. ${ }^{200}$ Both sides discussed issues of drawing a borderline. It was reported that some progress had been achieved, including an agreement that completed 90 percent of a common borderline. ${ }^{291}$ The following month saw the first round of talks of the Soviet-chinese group of diplomatic and military experts in Moscow. They discussed

288 Moscow TASS International Service in Russian, August 18, 1989, in FBIs-Sov-89-160, August 21, 1989, p. i3.

209 Pravda, October 14, 1989, p. 4, in FBIS-SOV-89-201, October 19, 1989, p. 15 .

200 Moscow in Mandarin to Southeast Asia, October 20, 1989, in FBIS-SOV-89-203, October 23, 1989, p. 19.

291 Moscow TASS International Service in Russian, October 31, 1989, in FBIS-SOV-89-110, November 1, 1989, p. 26. 
problems concerning a reduction of the armed forces of both sides along the border and the lssue of confidence-bullding in the military sphere. ${ }^{20}$ When the second round of talks was held in Beijing in February 1990, it was noted that for the first time in 30 years, military officials from both sides had not only met at the negotiating table, but also visited military installations. The Soviet officials visited a Chinese infantry division and armoured troops, while the chinese visited a soviet tank division and inspected combat aircraft. ${ }^{203}$

Visits by $L i$ Peng in April 1990 and Jiang zemin in May 1991: Perhaps, the most important contact after the Beijing Summit was Premier Li Peng's visit to Moscow from April 23 to 26, 1990. It was the first visit by a chinese premier since 1964. Li was accompanied by several high ranking officials, including Foreign Minister Qian Qichen. The main objective of the visit was to move forward the process of the development of bilateral relations.

During the three-day's visit, he met with the soviet President Gorbachev, Chairman N. I. Ryzhkov and Supreme Soviet President A. Lukyanov. Shevardnadze and Qian Qichen also held

2n Moscow in Mandarin to Southeast Asia, September 14 , 1989, in FBIS-SOV-89-220, November 16, 1989, p. 17.

293 Moscow Television Service in Russian, February 22, 1990, in FBIS-SOV-90-037, February 23, 1990, p. 10.

294 Moscow Television Service in Russian, April 25, 1990, in FBIS-SOV-90-081, p. 24. 
an official meeting during the visit. There was an in-depth exchange of oplnions on questions of bilateral relations and on international issues of inierest to both sides.

The visit concluded with the signing of a number of important documents, including an agreement on a long-term cooperation and development program in the fields of economy, science, and technology through the year 2000; an agreement on cooperation in the exploration and use of outer space for peaceful purposes; an agreement on guiding principles for a mutual reduction of military forces in border areas and strengthening trust in the military sphere. ${ }^{295}$ They also concluded an agreement on state credit for deliveries of consumer goods from china to the Soviet. Union, and a memorandum on intergovernmental cooperation on construction of a nuclear power station in China and the Soviet Union's offer of state credit to China. ${ }^{206}$

Li's visit gave a new impetus to the development of sinoSoviet relations. The signed agreements had solidified the legal foundations for bilateral contacts. The agreements on economic and technological cooperation, as well as on guiding principles for troop reduction along border were regarded as a further steps forward. Nevertheless, no formal communique

235 Moscow International Service in Mandarin April 25, 1990, in FBIS-SOV-90-081, April 26, 1990, pp. 21-22.

290 Pravda, April 27, 1990, p. 6, in FBIS-SOV-90-082, April 27, 1990, in p. 16. 
was issued at the end of the visit, even though both sides claimed Li's visit was a success.

In 1991, Jiang zemin, General secretary of the CPC Central Commission and chairman of the PRC Central Military Commission, paid a return visit for Gorbachev's visit to china in 1989. Jiang's visit coincided exactly with the second ar hiversary of tha Beijing Summit in 1989. In Moscow Jiang had talks with President Gorbachev, Chairman of the USSR Supreme Soviet A. Lukyanov, Premier V.S. Pavlov and other high-ranking officials. They exchanged opinions on issues of bilateral relations and on international topic of mutual interest.

During the Moscow visit, both sides signed an agreement on their common border. ${ }^{201}$ The soviet side even made a goodwill gesture toward China. On May 15, 1991, the first day of Jiang's visit, Moscow pulled out a contingent of troops stationed in Mongolia. Within the past two years, about threefourths of the 50,000 Soviet troops in Mongolia had been withdrawn. The significance of Jiang's visit was that on May 19 both sides signed a Soviet-Chinese communique which consolidated sino-soviet relations established during Gorbachev's visit in 1989.

297 Hoscow Radio Moscow World Service in English May 19, 1991, in FBIS-SOV-91-098, May 21, 1991, p. 22.

298 Moscow Radio Moscow in Mandarín, May 18, 1991, in FBIS-SOV-91-097, May 20, 1991, p. 19. 


\section{Bilateral sconomic Relations After the Bumit:}

Trade between China and the Soviet Union was facilitated by their complementary economies. When the United States and its allies imposed economic sanctions on China, the influx of capital to China decreased and scientific exchanges were reduced. This unfavourable situation forced China to pay more attention to expanding its cooperation with the Soviet Union.

The fourth session of the Soviet-Chinese Commission for Economic, Trade, Scientific and Technical Cooperation was held in Moscow in July $1989 .{ }^{290}$ Talks were conducted between Tian Jiyun, Chinese Deputy Premier of the state Council, and Yuriy Maslyukov, Chairman of the state planning Committee of the Soviet Union. They discussed a wide range of questions, particularly on cooperation in consumer goods production. ${ }^{300}$ At the end of meetings, an agreement was reached to formulate a long-term program through the year 2000 in the fields of economy, trade, science and technology. Moreover, both sides considered drafting an intergovernmental agreement for the utilization of Chinese manpower in the Soviet Union. ${ }^{3 / 1}$

In 1989 , the volume of bilateral trade reached 2.4 billion rubles (US\$3.95 billion). The growth was mainly from

299 Moscow TASS International service in Russia, July 20, 1989, in FBIS-SOV-89-139, July 21, 1989, p. 19.

300 Pravda, July 27, 1989, p. 4. in FBIS-SOV-89-144, July 28, 1989, p. 10 .

301 Ibid. 
the increased soviet purchases of consumer goods. ${ }^{302}$ The following year saw the bilateral trade exceed 3 billion rubles (US\$ 4.3 billion), ard border trade accounted for 20 percent of the total. By 1990, the Soviet Union had become China's fourth largest trade partner. ${ }^{300}$ Moreover, by 1990, nineteen joint sino-Soviet ventures had been registered in the soviet Union, with a total value of $30 \mathrm{million}$ rubles. Most of these enterprises were in the non-production areas, such as restaurants..$^{304}$

Given the similar economic system in both countries, and given that both were in a transition from a central-planned economy to a market-type economy, it was very helpful for them to exchange experiences and lessons in economic reform. Under these circumstances, the first soviet-chinese symposium on economic reforms was held in Moscow in March 1990. Scientists and economists gathered to discuss problems concerning economic reforms. Ismong them were Titarenko, a famous sinologist direcior of the Far East Institute of the USSR Academy of Sciences, Aganbegyan, one of the theorists for Soviet economic reform, and Liu Guoguang, vice President of the Chinese Academy of Social Sciences. According to the

302 Moscow International Service in Mandarin March 7 , 1990, in FBIS-SOV-90-051, March 15, 1990, p. 10.

$303 \mathrm{Yu}$. Savenkov. "The rogic of Mutual Trust", Izvestila, March 20,1991, p. 4. Text is translated in CDSP. Vol. XIIII, No. 12, April 24, 1991, p. 14.

304 Viktor Andreyev, and Dmitry Borisov. "USSR-China: Expanding Ties", Forelan Trade. No. 9, 1990, p. 18. 
conferees, the views exchanged and discussed were very meaningful. 305

When the fifth session of the sino-Soviet Committee on Economic, Trade, Scientific and Technical Cooperation was held in Beijing in July 1990, the two sides reaffirmed their mutual intention of expanding cooperation in these fields. Agreements on protecting investment and avoiding double taxation were signed. 306

At the end of a visit to China by Soviet Deputy Premier Yu. D. Maslyukov in March 1991, China agreed to provide the Soviet Union with a commodity loan worth 1 billion Swiss francs (US\$730 million), to let the 'JSSR purchase goods desperately needed such as grain, meat, tea, textiles and light industry products. The Soviet Union would repay the loan with manufactured goods and raw materials over a five year period. Maslyukov called the loan "very timely". ${ }^{307}$

During the process of broadening trade and economic ties, some problems such as the forms and methods of payments had arisen. Each side tried to sell products which could earn foreign currency on the world market. Some participants were reluctant to make commitment to trade agreements signed by the

305 Moscow International Service in Mandarin, February 17, 1990, in FBIS-SOV-90-050, March 14, 1990, pp. 11-12.

306 Moscow in Mandarin to Southeast Asia, July 22, 1990, in FBIS-SOV-90-141, July 23, 1990, p. 12.

307 Savenkov. "The Logic of Mutual Trust", in CDSP. April 24, 1991, pp. 13-14. 
two governments. Both sides felt that the clearing system of settlements was not only outdated, but also impeded the development of trade and economic relations. Consequently, they felt compelled to begin replacing the barter system in favour of using hard currency in their trade.

When the Chinese Minister of Foreign Economic Relations and Trade zheng Tuobin led a trade delegation to the soviet Union in october 1990, both sides agreed to sign an intergovernmental trade agreement, and a protocol on converting accounts and payments from clearing system of trade to hard currency kasis on bilateral trade and economic relations beginning January 1, 1991.308

The normalization of sino-Soviet relations had brought bilateral relations to extensive contacts. The five principles of peaceful coexistence, which were written in the joint communiçue at the 1989 Beijing summit, played an important role in Sino-Soviet :elations. As both sides adhered to these principles, especially one of noninterference in each other's internal affairs, the Event in Tiananmen's square did not affect the development of bilateral relations. In fact, after the June Fourth Event, China had shifted its focus of developing close relations with the United States and other Nestern countries to closer contact with the Soviet Union.

300 Maksim Bureyev. "Soviet-Chinese Trade: From clearing to Hard Currency Settlements", Foreign Trade. Nos. 11-12, 1990, p.13. 
The contacts and practical cooperation after the summit had been carefully separated from the political-ideological conflict. Both sides agreed that there was no single model for bullding socialism.

Li Peng's visit to the Soviet Union in 1990 was an important new milestone on the path of strengthening sinoSoviet relations. The visit by Jiang zemin to the soviet Union in May 1991 was another major step towards improvement of relations.

The sanctions by the United States and the West had compelled china to expand trade and economic contacts with the Soviet Union. The shift of payment to hard currency would cause a decrease in the total amount of bilateral trade in the short term, but in the long term it should produce a higher quality of goods and induce greater discipline among suppliers. 


\section{CONCIU8ION}

It was almost two decades after the sino-soviet split in the 1960 s that sino-soviet relations began to improve. The completion of normalized sino-soviet relations dia not come about overnight. It was the results of long-time negotiations between the two countries. It was the results of changes in the leadership of the two sides, and changes in the domestic and foreign policies of both nations, related to each other's position in the new setting of the international arena.

Both sides had a strong impetus to improve bilateral relations. On the soviet side, for strategic considerations, Gorbachev wanted to terminate the Sino-American ties as the result of Brezhr zv's military encirclement of china in the 1970s. Gorbachev also sought Beijing's cooperation against Washington's military strategy in the Asian-Pacific region. China's new independent foreign policy was perceived by Moscow as a precondition for sino-soviet normalization. Gorbachev also wanted better relations with China in order to fulfil the Soviet aim of cutting the military budget, through a reduction of Soviet forces along the Sino-Soviet border. Moreover, Gorbachev had a growing interest in China's economic reforms, as the Soviet Union was about to conduct economic reform. Given the geographic proximity, economic cooperation between the Soviet Union and China would especially contribute to the development of the Soviet Far East and Siberia, an ambitious programme under the Gorbachev administration. 
On the Chinese side, in order to ensure economic development and national security, the priority of chinese foreign policy was to ensure a peaceful and stable international environment, especially around china's periphery in the Asian-Pacific region. It was in China's interest to improve relations with neighbouring countries, including the Soviet Union. Improved relations with Moscow and stability along the sino-Soviet border would also let China considerably cut back its military spending. Furthermore, from the early 1980 s Beijing did not think of an imminent soviet invasion into China, which could be seen from cutting 1 million of the Chinese military forces in 1987. Thus, china in the early 1980 s perceived much less of a threat from the Soviet union than in the 1960s and 1970s.

Ideology, a key factor which led to the sino-soviet split in the late 1950, had changed greatly in the 1980s. Deng Xiaoping wanted a great effort in changing the backward Chinese economy in order to raise the Chinese living standards and strengthen national jower. Deng's pragmatism, which was contrary to Mao's idealism, made Chinese less interested in debating with the soviets on theoretical issues, such as war and peace, and the nature of international politics: questions which both sides argued endlessly in the past. on the contrary, in some cases, the identical socialist ideology had strengthened China's cooperation with the Soviet Union, particularly when Beijing was concerned about the western 
political and cultural influence brought about by its "open door policy". Furthermore, improved sino-soviet relations would also contribute to renovations and reconstruction of those state-owned enterprises built with soviet aid in the 1950s.

Nevertheless, in order not to jeopardize its relations with the United States and the West, China did not. move rapidly to normalize relations with the Soviet Union. In terms of advanced technology and a great amount of finance, China had more to gain from the United states and the West than from che Soviet Union. Considering this an not just national security, Chinese leaders chose not to rapidly normalize Sino-Soviet relations at the expense of the United States and the West. China put forward "the three obstacles" for sinoSoviet normalization, as a ploy to slow down the process and to gain the maximum price for resuming cordial relations. Thus, we have seen a long process of negotiations on sinoSoviet rapprochement.

From Brezhnev to Andropov and Chernenko, the soviet leaders made no concession on these three issues. Only with Gorbachev's Vladivostok speech in 1986 did a Soviet leader first deal with two of the three obstacles. From then on, Moscow gradually addressed these issues one by one.

The Gorbachev - Deng Beijing Summit in May, 1989 marked a turning point in sino-Soviet relations. The historic meeting fulfilled the mission of "closing the past and opening the 
future". It normalized bilateral relations and laid the foundation for creating a new type of sino-soviet relationship, based on the five principles: mutual respect for sovereignty and territorial integrity, non-aggression, noninterference in each other's internal affairs, equality and mutual benefit, and peaceful coexistence.

Economic relations between China and the Scviet Union had moved ahead of political relations. Trade relations developed long before the soviets addressed "the three obstacles". As Gerald segal pointed out:

The first phase of recent sino-soviet detente (i.e. the early 1980s) had seen most improvements in the cultural and economic spheres. It was apparently felt that this type of people-to-people diplomacy was softer and a useful way to test the ground for further detente. 309

In the eras of Khrushchev, Brezhnev and their two successors, the situation sf economic cooperation clearly reflected bilateral political relations. Poor political relations caused a decrease in economic cooperation. The new stage of bilateral economic relations was formed during Arkhipov's visit at the end of 1984 and Yao's visit in July 1985. The scale of trade and economic cooperations rose steadily. Though the amount of bilateral trade still remained a small part of each country's overall foreign trade, the increases rate of the sino-soviet economic cooperation was faster than with any other countries. The aims of regional

309 Gerald Segal. "Sino-Soviet Detente: the Long and Winding Road". The Journal of Communist studies. (1:1), March 1985, p. 24 . 
economic development in the Soviet Far East, Siber 1- : iviet Central Asia, China's north-east and north-west areas encouraged an improvement in sino-soviet relations. On the Chinese side, the "open door policy" had brought economic prosperity in South China, especially in the coast Provinces of Guangdong and Fujian. The regions of China's north-east and north-west had found themselirs at a disadvantaged situation in comparison with the rapidly developing South China. Thus, thuy had strong incentive to participate in international economic cooperation, especially with neighbouring countries such as Japan, the Soviet Union and South Korea. On the Soviet side, economic cooperation with bordering China could let the Soviet Far East, Siberia, Kazakhstan and the Soviet Central Asia obtain food products and consumer goods, of which in short supply in the soviet Union. It would also accelerate economic development in these soviet regions. And the interests of the provinces contiguous to the Soviet Union may have excercised influence on Beijing to improve sino-soviet relations. Therefore, the border trade along the sino-soviet border occupied a significant place in the economic cooperation.

The Joint Soviet-Chines? Commission on Economic, Trade, Scientific and Technical Cooperation played a considerable role in promoting bilateral cooperation. The annual meetings of the intergovernmental commission had caused trade and economic cooperation to expand further and wider. In the 
1980s, as the bilateral economic ties were complementary, both sides had a strong desire to have more contacts. The Soviet Union did play an important role in the construction of China's large enterprises, especially in the field of energy. since the 1989 normalization of Sino-soviet relations, contacts between the two sides at various levels and in different fields greatly increased. Both sides intensively discussed and exchanged experiences in the fields of economic and political reforms. They also came to the conclusion that there was no uniform way to build socialism and each had the right to choose its own road to socialism.

The Chinese prodemocratic demonstration in June 1989 which occurred during Gorbachev's visit to Beijing, did not effect the normalized bilateral relations. This was attributed to the five principles of peaceful co-existence, which both sides regarded as the guideline for the reestablished relationship. When the United States and other western countries condemned the violation of human rights in China, relations with these countries grew tense. The economic sanctions imposed on China by the U.S and the West pushed China into closer ties with the Soviet Union, especially in the field of economic cooperation.

When the Soviet Union collapsed after the failed coup in August 1991, the chinese regime chose a realistic approach toward the former soviet republics which declared their independence. Beijing recognized these independent countries 
and set up diplomatic relations with each of them. $\quad \mathrm{T} h \mathrm{e}$ collapse of the Soviet Union has fundamentally changed the relationship between China and the former soviet republics. Due to the internal political and economic difficulties, Russia and the other former republics have found that it is difficult for them to expand their military influence abroad. Thus, the former Soviet republics including Russia do not pose any direct threats to China's national security. 310 The future relations between China and Russia, and the cther former soviet republics will be an interesting topic for further study.

310 Guocang Huan. "The New Relationship with the Former Soviet Union", Current History. 91:566 (September 1992), p. 254 . 


\section{BIBLIOGRAPHY}

Information from Foreign Broadcast Information services (FBIS) provided a main source for this paper. Hcwever, due to the many 1tems of information used, it was not feasible to list all of ther in the bibliography. They are cited in the footnotes of each chapter.

\section{Boviet sourcrs:}

"A New stage in Soviet-Chinese Relations", Pravda, May 20, 1989, pp. 1-2. Text is translated in The Current Digest of The Soviet Press. Vol. XLI, No. 20, June 14, 1989, pp. 4-6.

Aleksandrov, I. "On Soviet-Chinese Relations", Prayda, May 20, 1982, pp. 4-5. Text is translated in The Eurrent Digest of The soviet Press. Vol. 34, No. 21, June, 23, 1982, pp. 14-15, 23 .

Andreyev, Viktor, and Borisov, Dmitry. "USSR-China: Expanding Ties", Eorelgn Trade. No. 9, 1990, pp. 18-19.

"Arrival in Peking", Pravda. December 22, 1984, p. 4. Text is translated in The current Digest of The soviet Press. Vol. XXXVI, No. 52, January 23, 1985, p. 1.

"At the Gates of Tiananmen", Pravda, May 16, 1989, pp. 1, 4. Text is translated in The current Digest of The soviet Press. Vol. XLI, No. 20, June 14, 1989, pp. 6-7.

Barakhta, Boris. "Useful steps", Pravda. September 17, 1986, p. 5. Text is translated in The current Digest of The soviet Press. Vol. XXXVIIJ, No. 37, Octuber 15, 1986, p. 10 .

Bazhanov, Evgeny. "End of 'Chinese Syndrome", New Times. May 8-14, 1990, pp. 5-6.

"On the Run-up to the Summit", New Times. May 9-15, 1989, pp. 33-35.

"Outlook for sino-Soviet Relations", New Times. February. 14-20, 1959, p.35.

October 3-9, 1989, pp. 19-22.

Bazhanov, Yevg. "Turnaround in 'Triangle Diplomacy ?"", Izvestila, July $22,1988, p, 5$. Text is translated in The Current Digest of The soviet Press. Vol. XL, No. 29, August 17, 1988, pp. 15-16. 
Bor 18ov, O. B. and Kuloskov, B. T. Sovlet-Chinese Relations, 1945-1970. (Translation) Bloomington \& London: Indiana University Press, 1975.

Brezhnev, L. I. "The Report of the CPSU Central Committee to the 26th Congress of the Communist Party of the Soviet Union and the Party's Immediate Tasks in the Fields of Domestic and Foreign Policy", Pravda and Izvestila, February 24, 1981, pp. 2-9. Text is translated in The Current Digest of The Soviet Press. Vol. 33, No. 8, March 25, 1981, pp. 3-21.

Bureyev, Maksim. "Soviet-Chinese Trade: From clearing to Hard Currency Settlements", Foreign Trade. Nos. 11-12, 1990, pp. 13-14.

Chudodeev, Alexander. "Two Tigers Fight", New Times. Novembr 13-19, 1990, pp. 30-31.

"Comrade L. I. Brezhrev's Stay in Uzbekistan", Pravda, March 2 . 1982, p. 1. Text is translated in The Current Digest ot The Soviet Press. Vol. 34, No. 12, April 21, 1982, pp. 1-8.

"Consultations Take Place", Izvestiia, December, 13, 1985, p. 4. Text is translated in The current pigest of The Soviet Press. Vol. XXXII, No. 50, January 8, 1986, pp. 5-7.

"Conversation in Peking", Pravda, December 24, 1984, p. 4. Text is translated in The current Digest of The soviet Press. Vol. XXXVI, No. 52, January 23, 1985, p. 2 .

"Discussion in the Kremlin", Pravda, April 25, 1990, pp. 1, 5. Text is translated in The current Digest of The soviet Press. Vol. XLII, No. 17, May 30, 1990, p. 14.

Golyakov, Sergei. "Moscow-Beijing", New Times. Feb. 7-13, 1989 , p. 28 .

"Good Prospects for the USSR and China", Izvestila, May 15, 1990 , p. 5. Text is translated in The Current Digest of The Soviet Press. Vol. XLII, No. 20, June 20, 1990, p. 22 .

"Gorbachev Answers L'Unita's Questions", Pravda, May 20, 1987, pp. 1, 3-4. Text is translated in The current pigest of The soviet Press. Vol. XXXIX, No. 20, June 17, 1987, pp. 15-17, 23.

Go:bachev, M. S. "The Political Report of the CPSU central Committee to the 27 th Congress of the Communist Party of 
the Sovlet Union", Prayda and Izyest 11a, February 26 , 1986, pp. 2-10. Text is translated in The current Digest of The Soviet Press. Vol. XXXVIII, No. 8, March 26, 1986, pp. 4-40.

Ignatenko, Vitaly. "Looking Ahead. Soviet Union-China: A Historlc Breakthrough", New Times. May 30-June 5, 1989, pp. 12--14.

Times. May $16-22,89$, pp. 5-7.

Visit to China is a watershed Between the Past and stage of Bilateral Relations.", New Times. May 23--t, 1989, pp. 5-8.

"In the Politburo of the cPSU Central Committee", Pravda, September 19, 1986, p. 1. Text is translated in The Current Digest of The Soviet Press. Vol . XXXVIII, No. 38 , October 22, 1986, p. 22 .

"Joint Soviet-Chinese Communique", Pravda and Izvestiia, May 19. 1989, p. 1. Text is translated in The current Digest of The soviet press. Vol. XLI, No. 20, June 14, 1989, pp. 2-4.

Kashirov, vladimir. and Shmelyov, Georgy. "Talks End", Izvestia, september 3, 1990, p. 4. Text is translated in The Current Digest of The soviet Press. Vol. XLII, No. 35, October 31990, p. 24 .

Kiryanov, Anatoli. "Trade and Economic Relations Between the Soviet Union and China Today", Eoreign Trade. No. 3, 1986, pp. 8-11.

International Affairs. (Moscow), October 1986 , pp. 154-155.

Kiryanov, Anatoli. and Kiryanova, Margarita. "USSR-People's Republic of China: Border Trade", Foreign Trade. No. 1 , 1987, pp. 16-18.

Kiryanova, Maryarita. "USSR-China: Prospects for Developing Trade and Economic Relations", Foreign Trẩe. No. 11, 1988, pp. 2-5.

Kobysh, V. and Savenkov, Yu. "Day Two", Izvestiia, May 16, $1989, p .1$. Text is translated in The Current Digest of The Soviet Press. Vol. XLI, No. 20, June 14, 1989, p. 7 . 
"Four significant Days",

Izvest11a, May 19,1989, p. 1 . Text is translated in The current Digest of The soviet Press. Vol. XLI, No. 20, June 14, 1989, pp. 7-8.

"Li Peng, Prime Minister of the CFri State Council, Concludes visit to the USSK", Pravda, April 27, 1990, p. 6. Text is translated in The current Digest of The soviet Prest. vol. XLII, No. 17, May 30, 1990, p. 15.

"Mass Demonstrations in Beijing", Pravda, May 20, 1989, p. 4. Text is tranclated in The current Digest of The soviet Press. Vol. XLI, No. 20 , June $14,1989, p$.

Matskevich, E. "'Great Rail Route' Opens", Izvestila, September 12, 1990, p. 1. Text is translated in The current Digest of The soviet Press. Vol. VLII, No. 37, October 17, 1990, p. 22

Matyaev, vladimir. "China: Development Results and Prospects", International Affairs. (Moscow), July 1987, pp. 145-147.

"Scine Aspects of China's Socio-Economic Development", International Affairs. (Moscow), November 1987, pp. 86-95.

"Meeting in Beijing", Izvestiia, January 13, 1990, p. 5. Text is translated in The current Digest of The Sovie 2 Press. Vol. VLII, No. 2, February 14, 1990, p. 28 .

Miasnikov, vladimir, et al. USSR-China in the Changing World. Moscow: Novosti Press Agency. 1989.

"Ministers Meet", Pravda, April 26, 1990, p. 5. Text is translated in The Current Digest of The Soviet Press. Vol. XLII, No. 17, May 30, 1990, pp. 14-15.

Nagorny, Alexander, and Sergei Tsyplakov. "The PRC: The First Decade of the Policy of Reforms", International Affairs. (Moscow), January. 1989, pp. 22-30.

"Ninth Round: Political Dialogue was Useful", Izvestiia, October 24, 1986, p. 5. Text is translated in The Current Digest of The Soviet Press. Vol. XXXVIII, No. 43, November 26,1986, p. 17 .

"On an official visit", Pravda, September 9, 1986, p. 4. Text is translated in The current Digest of The soviet Press. Vol. XxXVIII, No. 37, October 15, 1986, p. 9.

Ovchinnikov. V. "A Day of Businesslike Contacts", Pravda, May 17. 1989, pp. 2, 4. Text is translated in The Current 
Digest of The Sovlet Presg. Vol. XLI, No. 20, June 14, 1989, p. 7 .

"Normalized Soviet-Chinese Relations Bear Fruit", Pravda, May 15, 1990, p. 5. Text is translated in The Curcent Digest of The soviet Press. Vol. XLII, No. 20, June 20, 1990, p. 22.

Ovchinnikov, Vsevolod. "Beifing: Emphasis on stability", Pravda, April 10, 1990, p. 5. Text 1s translated in The Current Digest of The soviet Press. Vol. VLII, No. 15, May 16, 1990, pp. 22-23.

"Protocol signed", Pravda, March 22, 1986, p. 4. Text is translated in The current pigest of The soviet Press. Vol. XXXVIII, No. 12, April 23, 1986, p. 29.

"Political Consultations", Pravda, October 15, 1986, p. 4.

Text is translated in The current Digest of The soviet Press. Vol. XXXVIII, No. 41, November $12,1986, p, 18$.

Qian, Qichen. "Leaders of World Vemocracy: View from Beijing", International Affairs. (Moscc:s), August 1990, pp. 20-24.

Savenkov, Yu. "Martial Law Lifted in Beijing", Izvestiia, January 11, 1990, p. 5. Text is translated in The Current pigest of The soviet Press. Vol. VLII, No. 2, February 14, 1990, pp. 27-28.

-..-- "Passengers Rushing to China", Izvestiia, March 27, 1991, p. 4. Text is translated in The Current Digest of The soviet Press. Vol. XLIII, No. 13, May 1, 1991, p. 19 .

-..- "The Logic of Mutual Trust", Izvestiia, March 20, 1991, p. 4. Text is translated in The Current Digest of The Soviet Press. Vol. XLIII, No. 12, April 24, 1991, pp. 13-14.

Shcherbinin, Yu. "Well, Well!: Imported skirkers", Pravda, August $21,1990, p .6$. Text is translated in The Current Digest of The soviet press. Vol. XLII, No. 34, September 26, 1990, pp. 25-26.

"Speech by Comrade M.S. Gorbachev at the Ceremonial Meeting Devoted to the Presentation of the order of Lenin to vladivostok", Pravda and Izvestiia, July 29, 1986, pp. 1-3. Text is translated in The current Digest of The Soviet Press. Vol. XXXVIII, No. 30, August 27, 1986, pp. 1-8, 32 . 
"Speech by Comrade M.S. Gorbachev, General Secretary of the CPSU Central Committee, at the Plenary session of the CPsU Central Committee on March 11, 1985". Pravda and Izvestila, March 12, 1985, p. 3. Text is translated in The Current Digest of The soylet Press. Vol. XXXVII, No. 9. March 27, 1985, pp. 7-8,15.

"Soviet Government statement", Pravda and Izvestila, April 24 , 1986 , pp. 1, 4. Text is translated in The current Digest of The soviet Press Vol. XXXVIII, No. 17, May 28, 1986, pp. 6, 24 .

Soviet-Chinese Agreement", Izvestiia, June 1, 1986, p. 5. Text is translated in The current Digest of The soviet Press. Vol. XXXVIII, No. 20, July 2, 1986, p. 19.

"Soviet-Chinese Protocol on Trade", Izvestiia, January 25, 1986, p. 4. Text is translated ir. The current pigest of The soviet Press. Vol. XXXVIII, No. 4, February 26, 1986 , p. 20 .

"Stay in the CPR", Eravda, September 11, 1986, p. 4. Text is translated in Tre current Digest of The soviet Press. Vol. XXXVIII, No. 37, October $15,2: 86$, p. 9.

"Talks Completed", Pravda, December 29, 1984, p. 4. Text is tcanslated in The current Digest of The soviet Press. Vol. XXXVI, No. 52, January 23, 1985, p. 3 .

"Talks Held", Prâda, Decomber 24, 1984, p. 4. Text is translated in The current Digest of The soviet Press. Vol. XXXVI, :io. 52, January 23, 1985, p. 2 .

"Talks in Peking", Pravda, December 23, 1984, p. 4. Text is translated in The current Digest of The Soviet Press. Vol. XXXVI, No. 52, January 23, 1985, p. 1.

"The USSR and the CPR Normalize Relations: M.S. Gorbachev Meets with Deng Xiaoping", Pravda, May 17, 1989, p. 1. Text is translated in The Current Digest of The soviet Press. Vol. XLI, No. 20, June 14, 1989, p. 1.

"The Homeland's Award on the Banner of Vladivostok", Pravda, July 29, pp. 1-3. Text is translated in "Gorbachev Accents Soviet Role in Asia", in The current Digest of The Soviet Press. Vol. XXXVIII, No. 30, August 27, 1986, pp. 7-8.

Tolkunov, L. N. "Good-Neighbourliness is Necessary and Possible", Izvestila, December 11, 1985, p. 5 . Text is translated in The current Digest of The soviet Press. Vol. XXXII, No. 50, January 8, 1986, pp. 5-7. 
Tomashevsky, vladimir. "sino-soviet 'Petty' Trade: Some Problems outlined in the 1st sino-soviet Trade and Economic Relations Seminar", Eoreign Trade. No. 3, 1990, pp. 5-7.

"Touring the CPR", Pravda, December 28, 1984, p. 4. Text is translated in The current Digest of the soviet Press. Vol. XXXVI, No. 52, January 23, 1985, p. 3 .

Titarenko, M. "An Important Milestone", Pravda, September 18, 1986, p. 4. Text is translated in The curcent Digest of The soviet Press. Vol. XXXVIII, No. 37, October 15, 1986. p. 10 .

Developrent of CoopsR and China: For the Further 1987 . p. 6. Text is translated in The current The soviet Press. Vol. XXXIX, No. 39, October 28, 1987, pp. 8-10.

"Visit Ends", Pravda, September 16, 1986, p. 4. Text is translated in The Current Digest of The Soviet Press. Vol. XXXVIII, No. 37, October 15, 1986, p. 10.

"Visit to the CPR", Pravda, December 30,1984 , p. 4. Text is translated in The current Digest of The soviet Press. Vol. XXXVI, No. 52, January 23, 1985, p. 4.

Vneshnie Elonomicheskie Sviazi SSSR v 1985g. Moscow: Ministerstvo Vneshnoy Torgovii, 1985, p. 11, 15 .

Vneshnie Elonomicheskie Sviazi SSSR v 1986g. Moscow: Ministerstvo Vneshnoy Torgovli, 1986, p. 11, 15.

Vneshnie Elonomicheskie Sviazi SSSR $v$ 1987g. Moscow: Ministerstvo Vneshnoy Torgovii, 1987, p. 11, 15.

Vneshnie Elonomicheskie Sviazi SSSR $v$ 1988g. Moscow: Ministerstivo Vneshnoy Torgovli, 1988, p. 11, 15 .

Vneshnie Elonomicheskie Sviazi SSSR $v$ 1989g. Moscow: Ministerst:vo Vneshnoy Torgovii, 1989, p. 12, 16 .

Uneshnie Elonomicheskie Sviazi SSSR $v$ 1990g. Moscow: Ministerstvo Vneshnoy Torgovli, 1990, p. 12, 16.

Usmanov, Usman. "Diplomacy of Tajikistan", International Affairs. (Moscow), January. 1989, pp. 31-39.

Wang Pinging. "Sino-Soviet Trade and Economic Ties Today", Foreign Trade. No. 3, 1989, pp. 7-9. 
Yershov, Anatoly. "Chinese Workers at Gorky Automotive", Izvest 11a, August 11, 1990, p. 2. Text ls transiated in The current Digest of The soviet press. Vol. XLII, No. 32, September 12, 1990, pp. 20-21.

Yusin, M. "Harbin-Pyongyang-vladivostok-Tokyo", Izvestila, August $30,1990, p .5$. Text is translated in The Current pigest of The soviet Press. Vol. XLII, No. 35, October 3 , 1990, pp. 23-24.

\section{Chlnese 8ources:}

Ai, Ping. "Fighting Intensifies as Soviet Troops withdraw", Beijing Review. 31:36 (September 5, 1988;, p. 16 .

Cai, Ximei. "Sincerity Lacking on Kampuchean Issue", Beijing Review. 30:35 (August 31, 1987), p. 14.

China Daily. January 23, 1986, p. 1 .

"China Reaffirms Kampuchea Policy", Beijing Review 29:49 (December 8, 1986), pp. 15-16.

Cheng, Ying. "An Analytical study on the Potential Comeback of the Soviet Technological Advisers to the Mainland". studies on chinese Communism. (Monthly Journal, Taipei) $20: 9$ (September 15, 1986), pp. 40-44.

Chung, Mou. "The Economic Trade and S\&T Relations between the Chinese Communists and the Soviet Union at the Present stage", Studies on Chinese communism. (Taipei) 22:8 (August 15, 1988), pp. 61-68.

Deng, xiaoping. Selected Works of Deng Xiauping: 1975-1982. Beijing: Foreign Languages Press, 1984.

Duan, Pin. "Gorbachev in the Limelight Again", Beijing Review. 31:41 (October 10, 1988), p. 14 .

Feng, Xisnzhi. "Mao Zedong Reads Marxism-Leninism Works," Guang Ming Daily, December 26, 1990, p. 3 .

Hu, Yaobang. "Create A New situation in All Fields of Socialist Modernization -- Report to the 12th National Congress of the Communist Party of China, september 1 , 1982", Beijing Review. 25:37 (September 13, 1982), pp. $11-40$.

I, chung. "A survey of the status quo of the Chicom-Soviet Relations", studies on Chinese Communism. (Taipei) 18:6 (June 15, 1984), pp. 89-96. 
Jia, Be1. "Changing Soviet Relations with Major Powers in the Asia-Pacific Region", International studies. Beifing: Institute of International studies, 1991, No. 2. pp. 20-28.

Lin, Piao. "Report to the Ninth National Congress of the Communist Party of China", Peking Review. 12:18 (April 30, 1969), pp. 16-35.

Ma, Guang, and zhang, zhinian. "Peace Agreement signed in Geneva", Beiling Review. 31:17 (April 25, 1988), pp. 13-14.

"Soviet Troops Begin to Withdraw", Beijing Review. 31:22 (May 30, 1988), pp. 14-15.

Shi, zhongxing. "Soviet Troop Pullout only Gesture", Beijing Review. 29:43 (November 3, 1986), pp. 12-13.

"Sino-Soviet Summit Anticipated in 1989", Beijing Review. $31: 43$ (October 24, 1988), p. 9 .

"Sino-USSR Trade Makes Headway", Beijing Review. 31:31 (Auglist 1, 1988), pp. 7-8.

Song, Ximin. "Charyes in International Relations", Beijing Review. May 2, 1988, pp. 28-32.

Su, Xiaokang., Luo, Shixu., and Chen, zheng. Utopia: 1959 Lushan Meeting. Beijing: China News Agency, 1988.

"Talks Still Conditional", Beijing Review. 31:5 (February 1, 1988), p. 17 .

Tang, Tianri. "Supporting Kampuchean Peace Plan", Beijing Review. 29:16 (April 21, 1986), pp. 10-11.

Wang, Hsia-Jung. "An Analysis on the Status quo of the ChicomSoviet Economic and Trading Ties", Studies on chinese Ccmmunism. (Taipei) 21:4 (April 15, 1987), pp. 97-107.

CCP and CPSU and its Influence on Asia-Pacific Countries", studies on Chinese Communism. (Taipei) 23:9 (September 15, 1989), pp. 53-59.

Wei, Chang. "Li Peng's Visit to Moscow and the Development of the Relations Between CCP and CPSU", studies on Chinese Communism. (Taipei) 24:6 (June 15, 1990), pp. 29-36.

Wu, Jin. "China, USSR to Normalize Ties: A Trend", Beijing Review. 31:44 (October 31, 1988), pp. 27-28. 
Xin, Sheng. "Viet Nam Hands off Kampuchea", Beijing Review. 29:43 (November 3, 1986), p. 12.

Yang, Mu. "Three Decisions Vital to Anti-Vietnamese War", Beiling Review, 29:52 (December 29, 1986), pp. 14-15.

Yu, Chih. "An Analysis on the Talks over the Cambodia Issue Between the Chinese Communists and the Soviet Union", studies on Chinese Communism. (Talpei) 22:9 (September 15, 1988), pp. 42-51.

-.---- "An Analytical Probe into the Resumption of Border Talks Between the chinese Communist and the Soviet Union". Studies on Chinese Communism. (Taipei) 21:3 (March 15, 1987), pp. 45-52.

- "The Changes of the Chinese Communist's Relations with the Soviet Union and with Vietnam", studies on chinese Communism. (Taipei) 22:7 (July 15, 1988).

pp. 77-87.

Yue, Haitao. "Sino-Soviet Trade Booms", Beijing Review. 32:5 (January 30, 1989), pp. 29-30.

-...-.- "Sino-Soviet Trade Mounts", Beijing Review. 29:41, (October 13, 1986), p. 33 .

Zhang, Tiezang. "Soviet Reform Programme Faces Test", Beijing Review. 30 (January 11, 1988), pp. 120-122.

Zheng, Fangkun. "Why Hanoi Refuses Peace in Kampuchea", Beijing Review. 29:14 (Apri1 7, 1986) pp. 4-5, 34.

Zhang, zhinian. "Indirect Talks on Afghanistan Fruitless", Beijing Review. 30:38 (September 21, 1987), pp. 22-23.

\section{English 8ources:}

Abbasi, Abdur Razzaq Khan. "Sino-Soviet Relations", Strategic Studies. Summer 1988, pp. 79-91.

Ahmad, Sheikh Mutahir. "Sino-Soviet Rapprochement: Its Impact on South Asia", Paxistan Horizon. 43:1 (January 1990), pp. 79-88.

Aspaturian, Vernon V. "The Domestic Sources of Soviet Policy Toward China", in Douglas T. Stuart and William T. Tow (eds.) China, the Soviet Union and the West: Strategic and Political Dimensions in the 1980s. Boulder: Westview Press, 1982, pp. 39-57. 
Amiryar, Quadir A. "Afghanistan's Foreign Policy Dilema with China and the soviet Union : the Two Arch Rivals". Journal of Asian and African Affairs. 2:1 (July 1990). pp. 69-85.

Awanohart, Susurau. "No More Favours" Far Eastern Economic Review. Apiril 19, 1990. p. 12.

Bagley, Worth $W$. "Toward A Sino-Soviet Compact", Global Affairs. 4:3 (Summer 1989), pp. 1-11.

Barnett, A. Doak. China and the Major Powers in East Asia. Washington, D.C.: The Brookings Institution, 1977.

--- The Making of Foreign Policy in China: structure and Process. (SAIs Papers in international affairs), Bounder: Westview Press, 1985.

Becker, Jasper. "Toward a New Asian Equation: The End of 'Political Geometry'", World Press Review. May 1989, pp. 12-13.

Bialer, Seweryn. "New Thinking and soviet Foreign Policy", Survival. 30:4 (July/Aug. 1988), pp. 291-309.

Bonavia, David. "Deng and Gorbachev Face Demands of Materialism", Far Eastern Economic Review. April 9, 1987, pp. 28-29.

- "Gerontocracies Unite..." Far Eastern Economic Review. March 28, 1985, pp. 10-11.

"Keeping Peking in Touch", Far Eastern Economic Review. October 31, 1985, p. 20. Review. January 10, 1985, pp. 16, 19.

Boviı, Aleksandr. "The Doors Swing Open: Impact in Asia, the Pacific Rim", World Press Review. May 1989, pp. 13-14.

Bromke, Adam. "The Communist states and the West," in A. Bromke (ed.) The Communist states at the crossroads: Between Moscow and Peking. New York: Frederick $A$. Praeger, 1965, pp. 219-240.

Brzezinski, K. zbigniew. "Pattern and Limits of the sinoSoviet Dispute," problems of Communism. Vol. IX, September-cctober 1960 , pp. 1-7.

London: Harvard University Press, 1967. 
Cha1, Winberg. The Forelgn Relations of the People's Republic of Chlna. New York: G.P. Putnam's Sons, 1971.

Chanda, Nayan. "A Sumit in the Offing", Ear Eastern Economic Review. October 13, 1988, pp. 16-18.

-Diplomacy on the Air" Far Eastern Economic Review. September 18, 1986, p. 26.

- "Superpower Triangle", Far Eastern Economic Review. April 4, 1985, pp. 17-19.

- Review. March 5, 1987. pp. 17-18.

Far Eastern Economic

Chang, Ya-Chun. "The Peking-Moscow Summit", Issues and Studies. $25: 6$ (1989), pp. 9-12.

Chao, Chien-Min. "A Peking-Moscow Summit Impending", Issues and studies. 25:1 (1989), pp. 1-4.

Cheng, Chu-Yuan. Economic Relations Between Peking and Moscow. 1949-1963. New York: Praeger, 1964.

Cheng, Joseph Y. S. "China's Foreign Policy after the Fall of the Gang of Four", Asia Pacific Community, No. 10, Fall 1980 , pp. 51-67.

"China's Foreign Policy: Continuity and Change", Asian Quarterly, No. 4, 1976, pp. 296-326.

"China's Relations with the Two Superpowers in the Context of Modernization Diplomacy", Asian Perspective. Fall/winter 1988, pp. 157-159.

"Sino-Soviet Relations in the 1980s", Asian Pacific Community. Winter 1985, pp. 44-62.

Cheung, Tai Ming. "A Sale is in the Air", Far Eastern Economic Review. September 6, 1990, p. 20.

"Comrades in Arms", Far Eastern Economic Review. July 19, 1990 , p. 30 .

- Political Payoff", Far Eastern Economic Review. April 5, 1990, pp. 28-29.

Review. February 9, 1989, pp. 20-21.

Review. June 2, 1988, pp. 34-35. 
Chin, Calvin Suey Keu. A Study of Chinese Dependence Upon the Soviet Union for Economic Development as a Factor in communist China's Forelgn Pollay. Hong Kong: Union Research Institute, 1959.

Choudhury, Colam w. China in World Affairs: The Foreign Pollcy of ihe PRC Since 1970. Boulder, Colorado: Westview Press. 19:3:.

clement: Walter c. "Soviet Foreign Policy since 1917: Acl evements and Failures," Survey. (London), 30:4 (June 198.), pp. 87-112.

Daviso', Kenneth L. Jr. "The Geopolitics of the Soviet rithdrawal from Afghanistan", Strategic Review. 18:1 (winter 1990), pp. 39-48.

Day, Alan J. and Jones, Peter., Kevill, Sian. (eds.) China and the Soviet Union, 1949-1984. (Keesing's international Studies). London: Longman, 1985.

Delfs, Robert. "One Stage, Two Plays: Deng's Position Undercut at Moment of History", Far Eastern Economic Review. May 25, 1989, pp. 12-14.

- "Soviots Bearing Gifts - China is Wary of Gorbachev's New Froposals on Asia", Far Eastern Economic Review. November 13, 1986, pp. 32-35.

"Three Obstacles, Two Leaders, and One Problem", Far Eastern Economic Review. March 24, 1988, pp. 56-57.

Dittmer, Lowell. Sino-Soviet Normalization and Its International Implications, 1945-1990. Seattle and London: University of Washington Press, 1992.

do Rosario, Louise. "Don't Call Me Comrade: Sino-Soviet Rapprochement Advanced by Shevardnadze visit", Far Eastern Economic Review. February 16, 1989, pp. 10-11.

Dcmes, Jurgen. "Domestic Sources of PRC Policy Toward the USSR", in Douglas $T$. Stuart and William $T$. Tow (eds.) China, the Soviet Union and the West: Strategic and Political Dimensions in the 1980s. Boulder: Westview Press, 1982, pp. 25-38.

Doolin, Dennis J. Territorial claims in the sino-soviet Conflict: Documents and Analysis. California: Stanford University, 1965. 
Dutta, Suflt. "Sino-Soviet Relations: Recent Trends", Strategic Analysis. December 1988, pp. 955-965.

Ellison, Herbert J. "Changing Sino-Soviet Relations", Problems of Communism. 36:3 (May-June 1987), pp. 17-29.

"Sino-Soviet Rapprochement", Global Affairs. 4:3 (Summer 1989), pp. 12-29.

...-. The sino-Soviet conflict: A Global Perspective. Seattle: University of Washington Press, 1982 .

Eckstein, Alexander. Communist China's Economic Growth and Foreign Trade: Implications for U.S. Pollicy. New York: McGraw-Hill Book Company, 1966.

Falkenheim, Peggy L. The Soviet Union. China and Japan: Trilateral Relations in Flux. (Paper presented as part of the Canada the Pacific Programme funded by the Donner Canadian Foundation, Working Paper (17), Toronto: York University 1984.

Ferdinand, Peter. "Russian and Soviet Shadows over China's Future?" International Affairs. (New York: Cambridge University Press), 68:2 (April 1992). pp. 279-292.

Floyd, David. Mao Against Khrushchev: a Short History of the Sino-Soviet Conflict. New York: Praeger, 1964 .

Gang, Yu. "International Impacts of the Normalization of sinoSoviet Relations". International strategic studies. March 1989, pp. 11-14.

Garver, John. "Chinese Foreign Policy in 1970: The Tilt Towards the Soviet Union", China Quarterly. No. 82, June 1980, pp. 214- 249 .

Asian Survey. 29:12 (December 1989), pp. 1136-1152.

Gelman, Harry. "Outlook for Sino-Soviet Relations", Problems of Communism. Vol. XXVIII, Nos. 5-6, September-December, 1979, pp. 50-66.

(Autumn-Winter 1983), pp. 164-174.

"The Conflict: A Survey," Problems of Communism. Vol. XIII, March-April 1964, pp. 3-15. 
Ghoble, T. R. "China's Foreign Pollcy: Opening to the West ", Indla Quarterly. 44:1-2 (January-June 1988), pp. 39-58.

Glaubitz, Joachim. "Rapprochement Between China and the Soviet Union: Background and Prospects", Aussen Politik. 40:3 (1989), pp. 251-263.

Gill, Graeme. "The Soviet Union and Southeast Asia: A New Beginning?", Contemporary Southeast Asla. 10:1 (June 1988), pp. 69-81.

Gittings, John. Survey of the sino-soviet Dispute: A Commentary and Extracts from the Recent Polemics 19631967. London: Oxford University Press, 1968.

Goldman, Marshall I. "Soviet Perceptions of Chinese Economic Reforms and the Implications for Reform in the USSR", Journal of International Affairs. December 1986. pp. 33-40.

Goldstein, Steven M. "Diplomacy Amid Protest: the Sino-Soviet Summit", Problems of Communism. 38:5 (1989), pp. 49-71.

Griffith, william E. "Sino-Soviet. Rapprochement?" Problems of Communism. 32:2 (March-April 1983), pp. 20-29.

"The Sino-Soviet Split: A Reconstructed History, 1956-1964," in Bromke, Adam. (ed.) The Communist States at the Crossroads: Between Moscow and Peking. New York: Frederick A. Praeger, 1965. pp. 43-55.

Gustafson, Thane. "will Soviet Foreign Policy Change Under Gorbachev?" The Washington Quarterly. 9:4 (Fall 1986), pp. 153-157.

Gurtov, Melvin and Hwang, Byong-Moo. China Under Threat: The Politics of Strategy and Diplomacy. Baltimore and London: The Johns Hopkins University Press, 1980.

Ha, Joseph M. "Gorbachev's Bold Asian Initiatives: Vladivostok and Beyond", Asian Perspective. 21:1 (Summer 1988), pp. 5-30.

Harding, Harry. (ed.) China's Foreign Relations in the 1980 s. New Haven and London: Yale University Press, 1984.

Hart, Thomas G. "Sino-Soviet State Relations 1969-1982: An Attempt at Clarification", Cooperation and conflict. 18:2 (1983) pp. 79-99. 
Hao, Yuafan. "The Development of the soviet Far East: A Chinese Perspective", Korea and VIId Affairg. 15:2 (Summer 1991), pp. 230-258.

Hao, Yufan. and Huan, Guocang. (eds.) The Chinese View of the World. New York: Pantheon Books, 1989.

Hao, Yufan. and Huan, Guocang. "Chinese Forelgn Pollcy in Transition", in their eds. The Chinese View of the World. New York: Pantheon Books, 1989, pp. xi-xxix.

Hiekert, Murray. "Cambodia Discord", Far Eastern Economic Review. June 28, 1990. pp.16-17.

Heinzig, Dieter. "The Soviet Union and China: Headed Toward a New Conflict?" Aussen politik. 41:3 (1990), pp. 258-267.

Hinton, Harold $c$. The Bear at the Gate: Chinese Policy making under soviet Pressure. California: Stanford University. 1971 .

"Moscow and Peking since Mao", Current History. 75:440 (Ociober 1978), pp. 120-122, 126-127.

(ed.) The People's Republic of China: a Handbook. Boulder: Westview Press, 1979.

The Sino-Soviet cunfrontation: Implications for the Future. New York: Crane, Russak Company, Inc. 1976.

"Sino-Soviet Relations: Background and Overview", in stuart, Douglas $T$. and Tow, william $T$. (eds.) China, the Soviet Union and the Vest: strategic and Political Dimensions in the 1980s. Boulder: Westview Press, 1982, pp. 9-23.

Hiramatsu, Shigeo. "A Chinese Perspective on sino-soviet Relations", Journal of Northeast Asian studies. 2:3 (September, 1983), pp. 51-65.

Holloway, David. "Gorbachev's New Thinking", Foreign Affairs. $68: 1$ (1988/1989), pp. 66-81.

Holmes, Leslie. "Afghanistan and Sino-Soviet Relations", in Saikal, Amin. and Maley, William (eds.) The soviet Withdrawal from Afghanistan. Cambridge, New York: Cambridge University Press, 1989, pp. 122-141.

Horn, Robert c. "China and Russia in 1977: Maoism without Mao", Asian Survey. 17:7 (July 1977), pp. 919-930. 
"Soviet Leadership Changes and Sino-Soviet Relations", Orb1s. 30:4 (winter 1987), pp. 683--699.

-........... "Soviet Policy in East Asia", Curxent History.

$86: 522$ (October 1987), pp. 321-324.

(Vietnam and sino-Soviet Relatiors: What Price Rapprochement", Asian Survey. 27:7 (July 198:), pp. $729-747$.

Hoon, Shim Jae. and Awanohara, Susumu. "Perestroika Pay-off", Far Eastern Economic Review. June 14, 1990. pp. 10-11.

Hsiung, James C. "Reagan's China Policy and the Sino-Soviet Detente", Asian Affairs: An American Revie'w. Summer 1984, pp. 1-11.

- Sino-Soviet Detente and Chinese Foreign Policy", Current History. 87:530 (September 1988), pp. 245-248, 277-278.

Huan, Guocang. "Dynamics of Sino-Soviet Relations", Atlantic Community Quarterly. 24:1 (Spring 1986), pp. 39-49.

............ "Sino-Soviet Relations", in Hao, Yufan and Huan, Guocang (eds.) The chinese View of the World. New York: Pantheon Books, 1989. pp. 103-139.

washington Quarterly. 14:2 (Spring 1991), pp. 143-161.

"The New Relationship with the former soviet Union", current History. 91:566 (September 1992), pp. 253-256.

Hwang, Tien-chien. Moscow-Peiping Relations and Khrushchev-Mao struggle. Republic of China: Asian People's AntiCommunist League, October 1963.

"Interview with 2ho Qizhen, Vice Minister of Foreign Affairs of the People's Republic of China", Journal of Northeast Asian Studies. 2:2 (Summer 1984), pp. 73-79.

Ishii, Akira. and International Institute for Global Peace. Chinese Political/Economic Reform and the Soviet Union. China committee Report - - Volume II. IIGP Special Report. Tokyo: The Institute. April 1990.

Jacobsen, Carl G. "Sino-Soviet Crisis in Perspective", current History. 77:450 (1979), pp, 110-114, 133-135. 
story". (Paper for World sovlet studies Iongress, Harrogate, England, 1990.)

Sino-soviet Relations since Mao: The Chairman's Legacy. New York: Praeger, 1981.

Jia, Qlnguo. "China's Forcign Economir Policy", in Hao, Yufan and Huan, Guocang (eds.) The Chinese View of the World. New York: Pantheon Books, 1989, pp. 59-76.

Jones, Peter. and Kevill, Sian (compiled). China and the Soviet Union 1949-1984. (Keesing's International studies) London: Longman, 1985.

Keeble, Curtis. "The Rocts of soviet Foreign Poliny", International Affairs. (Lonäon: Vol.60, 1984, pp. 561-578.

Keesing's Research Archive - Record of Wor c Events. Vol. XXXI, No. 3, 1985 .

Keesing's Research Archives: Record of World Events. Vol. XXXII, No. 10,1986 .

Keesing's Researrh Archives: Record of World Events. Vol. XXXIII, No. 4, 1987 .

Keigh, Ronald $c$. "The Origins and strategic Implications of China's Independent Foreign Policy", International Journal. 41:1 (Spring 1985), pp. 97-108.

Kim, Samuel. "Chinese Foreign Policy After Tiananmen", Current History. 89:549 (September 1990), pp. 245-248, 280-282.

Kimura, Hiroshi. "Gorbachev's Foreign Policy in hsia and the Pacific", Japan Review of International Affairs. Summer 1987, pp. 62-94.

"Soviet Focus on the Pacific", Problems of Communism. 36:3 (May-June 1987), pp. 1-16.

Knight, Gregory D. "China's Soviet Policy in the Gorbachev Era". The Washington Quarterly. 9:22 (Spring 1986), pp. 97-108.

Kui, Xu. "The Prospects of sino-Soviet Relatiors", Foreign Affairs Journal. June 1989, pp. 28-37.

Lampton, David M. "China's Limited Accommodation with the USSR", AEI Foreign Policy and Defense Review. September 1,1986 , pp. 26-35. 
Lardy, Nicholas. "Sino-Soviet Economic Relations: Prospects and Implications for U.S. Policy", sino-soviet Relations After the Summit. (A Workshop Sponsored by the Senate Foreign Relations Committee and the Congressional Research Service, May 15, 1989), Washington, D.C.: U.S. Government Printing office, Feb. 1990. pp. 113-120.

Laqueur, Walter. "Glasnost Abroad: New Thinking in Foreign Policy". The Washirgton Quarterly. 11:4 (Autumn 1988), pp. 75-94.

Lawrance, Alan. China's Foreign Relations Since 1949. London: Routledge Kegan Paul, 1975.

Lee, Mary. "A Back Seat for Politics", Far Eastern Economic Review. January 10, 1985, pp. 15-16.

"A Crack in the Ice", Far Eastern Economic Review. March 28, 1985, pp. 10-11.

--.--- "Two-way Street for Arms", Far Eastern Economic Review. December 12, 1985, p.25.

Legvold, Robert. The New Thinking and Gorbachev's Foreign Policy. New York: Institute for East-West security studies, July 1987.

- The Revolution in Soviet Foreign Policy", Foreign Affairs: America and the World 1988/1989. 68:1 (1988/1989!, pp. 82-98.

Leng, Shao-Chuan. "Legal Aspects of the Sino-Soviet Dispute", Asian Survey. 12:6 (June 1972), pp. 493-509.

Levine, steven $T$. "Second Chance in Clina: sino-soviet Relations in the 1990s" Annals of the American Academy of Political and Social Science. Vol. 519, January 1992, pp. 26-38.

"The End of Sino-Soviet Estrangement", Current History. 85:512 (September 1986), pp. 245-248, 279-280.

"The Uncertain Future of chinese Foreign Policy", Current History. 88:539 (September 1989), pp. 261-264, 295-296.

"The Unending Sino-Soviet Conflict", Current History. 79:459 (October 1980), pp. 70-74, 104.

Livermore, Gordon (ed.) Soviet Foreign Policy Today: Report and Commentaries from the soviet Press. 3rd ed. 1929. 
Low, Alfred D. The sino-soviet Confrontation since Mao zedonq: Dispute, Detente, or Conflict? New York: Bonlder: Social Science Monographs. 1987.

Lowenthal, R. "Factors of Unity and Factors of Conflict", Annals of the American Academy of Political and Social Science. September 1963, pp. 106-116.

Macridis, Roy C. Contemporary Political Ideologies: Movements and Regimes. Glenview: Scott, Foresman and Company, 1989.

Mahnken, Thomas G. "Current Sino-Soviet Military Relations", Asian Affairs, An American Review. 14:2 (Summer 1987), pp. 91-105.

Manning, Robert A. "Moscow's Pacific Future: Gorbachev Rediscovers Asia", World Policy Journal. 5:1 (Winter 1988), pp. 55-78.

Mason, T. David. "Sino-Soviet Relations Amid the Transition in Leadership", Korean Journal of International studies. 17:4 (Autumn 1986), pp. 23-71.

Mcgregor, Charles. The sino-Vietnamese Relationship and the Soviet Union. London: International Institute for Strategic Studies, 1983 (Adelphi Paper 232).

Medvedev, Roy Aleksandrovich. China and the Superpowers. Oxford; New York: Blackwell, 1986.

Medvedev, Roy. "The USSR and China: Confrontation or Detente?" New Left Review. No. 142, November-December 1983, pp. 529 .

Mehrotra, O.N. "Sino-Soviet Rapprcchement", Strategic Analysis. August 1989, pp. 511-522.

Mei, Yan "The Maturing of Soviet-Chinese Rela"ions", Annals of the American Academy of Political anu Social science. vol. 481, September 1985, pp. 70-80.

Meissner, Boris. "New Thinking and Soviet roreign Policy", Aussian Politik. 40:2 (1989), pp. 101-11s.

Menon, Rajan. "China and the Soviet Union in Asia", current History. 80:468 (October 1981), pp. 329-333, 340-342.

Menon, Rajan and Daniel Abele. "Security Dimensions of Soviet Territorial Dispute with China and Japan", Journal of Northeast Asian Studies. 8:1 (Spring 1989;, pp. 5-19. 
Michael, Franz. "The struggle for Power," Problems of Communism. May-June 1967, pp. 12-21.

Miller, Elisa. "The USSR's Asia-Pacific Rim: New Economic Efforts in the Soviet Far East", Pacific Northwest Executive. 4 (July 1988), pp. 20-25.

Mills, william deB. "Baiting the Chinese Dragon: Sino-Soviet Relations atter Vladivostok", Journal of Northeast Asian Studies, 6:3 (Fall 1987), pp. 3-30.

\section{"Dynamically Modelling Peking-Moscow}

Rapprochement", Issues and studies, 27:2 (February. 1991). pp. 21-35.

-Gorbachev and the Future of Sino-Soviet Relation", Policical Science Quarterly. 101:4 (1986) pp. 535-557.

"The Price of Propaganda in Sino-Soviet Relation", Journal of Northeast Asian Studies. $3: 4$ (Winter 1984), pp. 43-60.

Newby, Laura. "Sino-Soviet Rapprochement and its Implication fcr China's Foreign Policy", RUSI and Brassey's Defence Yearbook. 1990, pp. 377-394.

Nations, Richard. "A $\$ 14$ Billion Deal", Far Eastern Economic Review. July 25, 1985, pp. 12-13,

-...- "China Mafia' Doomed as Ties with Peking Improve", Far Eastern Economic Review. August 14, 1986, pp. 36-37.

. "Derg Xiaoping's Reforms Worry Kremlin's Bosses", Far Eastern Economic Review. August 14, 1986, pp. 34-35.

Review. August 14, 1986, pp. 30-34.

Tension", Far Eastern Economic Review. March 27, 1986. p. 10 . 
Neso, Peter Van. Revolution and Chlrese Forelgn Policy: Peking's support for Wars of National Liberation. California: University of California Press, 1970.

Nobilo, Mario. "Prospects of sino-Soviet Rapprochement", Review of International Affairs. Vol. 34, December 20, 1983, pp. 16-18.

Nossov, Mikhail G., "The USSR and the Security of the AsiaPacific Region", Asian Survey. 39:3 (March 1989), pp. 252-267.

Ogawa, Heishiro. "A Diplomat's View of China's Foreign Policy", Asian Pacific Community. No. 17, Summer 1982, pp. 89-10:

Oksenberg, Michael. "Mao's Policy Commitments, 1921-1976", Problems of Communism. Vol. XXV, November-December 1976, pp. 1-26.

Peric, Milan. "Chinese-Soviet Consultations", Review of International Affairs. Vol. 34, April 20, 1983, pp. 27-30.

Pin, Ying-Hsien. "Gorbachev's New Political Thinking and Soviet Policy in the Asia-Pacific Region", Issues and Studies. 25:6 (June 1989).

- Normalyzation of Peking-Moscow Relations: The Process and Prospects", Issues and Studies. 21:8 (August, 1985), pp. 104-124.

Issues and Studies. 11:3 (March 1975), pp. 58-70.

- "Peiping-Moscow Relations in the Post-Treaty Era: The Search for a New Framework", Issues and Studies. $17:$ i (August 1981), pp. 48-63.

Peng's Visit to the Soviet Union" 26:9 (September, 1990), pp. 12-26.

. Issues and Stuaies. 23:11 (November 1987), pp. 96-114 and Studies. 25:9 (1989). pp. 105-118.

Pravda, Alex. "Is there a Gorbachev Foreign Policy?", The Journal of Communist studies. 4:4 (December, 1988), pp. 100-120. 


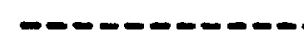

Soviet Foreign Pollcy: Priorities under Gorbachev. London: Routledge. 1988. (Chatham House Papers).

Pollack, Jonathan D. "China's Agonizing Reappraisal", in Herbert J. Ellison (ed.) The sino-soviet conflict: A Global Perspective. Seattle and London: University of Washington Press, 1982, pp. 50-73.

Economic Review. June 1, 1989, pp. 22-23.

Qaiser, Aileen. "China's Interest in Afghanistan: In the ccntext of Sino-Soviet Rivalry", strategic studies. Winter 1987, pp. 56-66.

Quested, R.K.I. Sino-Russian Relations: A Short History. Sydney; Boston: G. Allen $f$ Unwin, 1984 .

Quinn-judge, Sophie., Robert Delfs and Nayan Chanda. "Clearing the Peking Road", Far Eastern Economic Review. October, 15,1988, p. 17 .

Quinn-Judge, Sophie. "Li's 'Indulgence"", Far Eastern Economic Review. May 10, 1990, pp. 10-11.

Review. June 21, 1990, pp. 22-23.

"Pragmatic Partners: Li Peng goes to Moscow for Military and Trade 'alks", Far Eastern Economic Review. April 26, 1990, pp. 12-13.

. "Reduction Resistance", Far Eastern Economic Review. March 16, 1989, p. 22.

Rafael, Edgard. "Sino-Soviet Competition in the Balkans", in stuart, Douglas T. and Tow, William T. (eds.) China, the Soviet Union and the West: Strategic and Political Dimensions in the 1980s. Boulder: Westview Press, 1982, pp. 223-231.

Rea, Kenneth $\omega$. "Peking and the Brezhnev Doctrine", Asian Affairs: An American Review. 3:1 (September/October 1975), pp. 22-30.

Riedmiller, Josef. "Negotiating the silk Route Between Moscow and Peking", German Tribune. May 28, 1989, p. 2 .

Roberts, Cynthia."The New Realism and old Rigidifies: Gorbachev's strategy in Perspective", The washington Quarterly. 11:3 (Summer 1988), pp. 213-224. 
Robinson, Thomas w. "Chinese-Soviet Relations in the Context of Asian and International Politics", International Journal. 34:4 (Autumn 1979), pp. 624-648.

"sino-Soviet competition in Asia", in stuart, Douglas T. and Tow, William T. (eds.) China, the Soviet Union and the West: Strategic and Political Dimensions in the 1980s. Boulder: Westview Press, 1982, pp. 175-186.

- The New Era in Sino-Soviet Relations", Current History. 86:521 (September 1987),

pp. 241-244, 303-304.

"The soviet Union and Asia in 1981", Asian Survey. $22: 1$ (January 1932), pp. 13-32.

Rosario, Louise do. "Don't Call Me Comrade", Far Eastern Economic Review. February 16, 1989, pp. 10-11.

Economic Review. January 1, 1987, pp. 46-47.

Review. May 25, 1989, pp. 15-16.

Rozman, Gilbert. The chinese Debate about Soviet Socialism. 1978-1985. Princeton: Princeton University Press, 1987.

- China's Soviet watchers in the 1980s: A New Era in Scholarship", World Polities. 37:4 (July 1985), pp. 435-474.

"Moscow's China-Watchers in the Post-Mao Era: The Response to a Changing China", China Quarterly. No. 94, June 1983, pp. 215-241.

Salitsky, Alexander. "Communist Economjc Giants", Far Eastern Economic Review. May 18, 1989, pp. 20-21.

Sanders, Alan. "Let's Make Friends", Far Eastern Economic Review. January 10, 1985, pp. 32-33.

"Looking Beyond the steppe: Sino-Scviet Relations Remain the Key to the Future", Far Eastern Economic Review. December 10, 1987, pp. 39-44.

Sarty, Leigh. "Canadian-Soviet Relations, 1955-1989: Three Encounters," (Occasional paper), 35 pgs.

Scalapino, Robert A. "Containment and Countercontainment: The current stage of sino-soviet Relations", in stuart, 
Douglas T. and Tow, W1111am T. (eds.) China, the sovlet Union and the West: strategic and Political Dimensions in the 1980s. Boulder: Westview Press, 1982, pp. 159-174.

Scherer, John L., (ed.) USSR Facts and Figures Annual: 1977,

US: Academic International Press, Vol. 1, 1977.

Segal, Gerald. "China and the Great Power Triangle", The China Quarterly. No. 83, september 1980, pp. 490-509.

"Sino-Soviet Detente: the Long and Winding Road", Journal of Communist Studies. 1:1 (March 1985), pp. 21-33.

World Today. 43:5 (May 1987), pp. 87-91.

-..- Sino-Soviet Relations after Mao. London: the International Institute for strategic studies, 1985. (Adelphi Papers, No. 202)

World Today. 44:6 (June 1988), pp. 95-99.

clark (ed.) Gorbachev's Agenda: Changes in soviet Domestic and Foreign Policy. Boulder: Westview Press, 1989, pp. 313-353.

- "Taking sino-Soviet Detente seriously", The Washington Quarterly. 12:3 (Summer 1989), pp. 53-63.

Sestanovich, stephen. "Gorbachev's Foreign Policy: A Diplomacy of Decline?", Problems of Communism. 37:1 (JanuaryFebruary 1988), pp. 1-15.

Shao, Wenguang. "China's Relations with the super-Powers", Survival. March/April 1990, pp. 157-172.

Simes, Dmitri. "Gorbachev: A New Foreign Policy?", Eoreign Affairs. $65: 3$ (1987), pp. 47i-500.

simon, Sheldon $w$. "The sino-Soviet Future: Some PRC Perspectives", Third world Quarterly' 11:3 (July 1989), pp. 85-106.

strode, Dan L. "Soviet China Policy in Flux", Survival. 30:4 (July/August 1988), pp. 332-350.

strong, John w. "Sino-Soviet Relations in Historical Perspective", in Bromke, Adam. (ed.) The Communist 
States at the Crossroads: Between Hoscow and Peking. New York: Frederick A. Praeger, 1965, pp. 21-42.

stuart, Douglas $T$. and william $T$. Tow. (eds.) China, the Soviet Union, and the West: Strategic and Political Dimensions in the 1980s. Boulder, Colo: Westview Press, 1982.

Su, Chi. "China and the Soviet Union", Current History. 83:494 (September 1984), pp. 245-247, 281.

- "Soviet China-Watchers" Influence on Soviet China Policy", Journal of Northeast Asian studies. $2: 4$ (December 1983), pp. 25-49.

"sino-soviet Relations of the 1980s: From Confrontation to Conciliation", in samuel s. Kim (ed.) China and the world: New Direction in Chinese Foreign Relations. (Second Edition) Boulder: Westview Press, 1989, pp. 109-127.

Suharchuk, Gregorii D. "Modernization in China and Foreign Policy", Asian Survey. 24:11 (November 1984), pp. 1157-1162.

Sutter, Robert G. "Changes in Eastern Europe and The Soviet Union: The Effects on China", Journal of Northeast Asian studies. Simmer 1990, pp. 34-45.

"Peking's Relations with Vietnam and Korea: Implications for Future changes in Peking's Foreign Policy", Issues and studies. 23:9 (September 1987), pp. 92-114.

Tai, sung An. The sino-soviet Territorial Dispute. Philadelphia: The Westminster Press, 1973.

Talbott, strobe. "Swords into Sample Cases: on the Heavily Armed sino-soviet Border, Tension is Giving Way to Trade", Time. July 18, 1988, pp. 28-30.

Tedstrom, John. "Soviet Trade with China", Radio Free Europe. (RL 210/88), May 17, 1988, pp. 2-3.

Thakur, Raniesh. "Coexistence to Conflict: Hanoi-Moscow-Peking Relations and the China-Vietnam War", Australian outlook. 34:1 (April 1980), pp. 64-74.

Thakur, Ramesh and Carlyle A. Thayer (eds.) The Soviet Union as an Asian Pacific Power: Implications of Gorbachev's 1986 Vladivostok Initiatives. Boulder, Co: Westriew Press, 1987. 
Tsui, Tsien-hua. The Sino-Soviet Border Dispute in the 19708 . Oakville: Mosaic Press: 1983.

Ulam, Adam. Expansion and Coexistence: the History of Soviet Foreign Policy 1917-1967. New York: Fredirck A. Prager, 1968 .

United States. Senate. Committee on Foreign Relations. SinoSoviet Relations After the Summit. Washington, D.C.: U.S. Government Printing office, February 1990.

Urban, Joan Barth. "Gorbachev and World Communism: Collapse or Perestroika?", Problems of Communism. 37:5 (SeptemberOctober 1988), pp. 71-76.

Uren, Philip E. "Economic Relations Among the Communist States", in Bromke, Adam. (ed.) The communist states at the Crossroads: Between Moscow and Peking. New York: Frederick A. Praeger, 1965, pp. 199-218.

Veen, Hans-Joachim. From Brezhnev to Gorbachev: Domestic Affairs and Soviet Foreign Policy. New York: St. Martin's Press, 1987.

Wallace, william v. "Sino-Soviet Reiations: An Interpretation", soviet Studies. 45:4 (October 1983), pp. 457-470.

Wang, Cheng-Chung. "Normalization of Peking-Moscow Relations", Issues and ctudies. 25:4 (April 1989), pp. 57-75.

Whiting, Allen S. "Sino-Soviet Relations: What Next?" Annals of the Aulerican Academy of Political and Social Science. Vol. 476 (November, 1984), pp. 142-155.

Wilson, Dick. "China's Affair with Russia", Asian Pacific Community. No. 7, winter 1980, pp. 66-78.

Woods, Lawrence T. "Delicate Diplomatic Debuts: Chinese and Soviet Participation in the Pacific Economic Cooperation Conference", Pacific Affairs. 63:2 (Summer 1970).

Wu, Aitchen K. China and the Soviet Union: A Study of SinoSoviet Relations. London: Methuen \& Co. Ltd. 1950.

Xinan, Wu. "1he Present Status and Prospects of Sino-Soviet Relations", Strategic Studies. Sumwer 1988, pp. 75-78.

Yang, Shouzheng. "Sino-Soviet Kelations; Past, Future and Implications", Foreign Affairs Journal. June, 1989, pp. 22-27. 
Yao, Meng-hsuan. "Peiping's Current Foreign Policy", Issues and studies. $10: 13$ (1974), pp. 2-22.

Yee, Herbert s. "The Three World Theory and Post-Mao China's Global Strategy", International Affairs. (London) 59:2 (1983). pp. 239-249.

Yin, Ching-Yao. "Peking-Moscow Relations: An Analysis", Issues and Studies. $22: 3$ (1986), pp. 34-53.

Yourg, Stephen M. "Gorbachev's Asian Policy: Balancing the New and the old". Asian Survey. 28:3 (March 1988), pp. 317-339.

Zacek, Jane Shapiro. (ed.) The Gorbachev Generation: Issues in Soviet Foreign Policy. New York: Paragon, 1989.

Zagreg, Zivorad Petrovic. "Sino-Soviet Economic Cooperation", Review of International Affairs. Vol. 37, December 20, 1986, pp. 27-29.

Zagoria, Donald $s$. "The Moscow-Beijing Detente", Foreign Affairs. 61:4 (Spring 1983), pp. 853-873.

- The Moscow-Beijing Detente", In Laird, Robbin F. and Hoffmann, Erik P. (eds.) Soviet Foreign Policy in a Changing World. New York: Aldine Publishing Company, 1986, pp. 681-698.

1956-1961. London: Princeton University Press, 1962. Beginning?" Foreign Affairs: America and the World 1988/1989. $68: 1(1988 / 1989)$, pp. 120-138.

Constructive "Soviet Pollcy in East Asia: the Quest for Constructive Engagement", Korean Journal of Defense Analysis. (Summer 1990), pp. 7-31.

Zhao, ziyang. "The objectives of China's Foreign Policy: For Lasting Peace, Increased Friendly cooperation, and coprosperity", International Affairs. (Great Britain) 61:4 (Autumn 1985). pp. 577-580.

Zhu, Hongqian. "China and the Triangular Relationship", in Hao, Yufan ard Huan, Guocang (eds.) The Chirese View of the World. New York: Pantheon Books, 1989, pp. 33-56.

Zwick, Peter. Soviet Foreign Relations: process and Policy. New Jersey: Prentice Hall, 1990. 

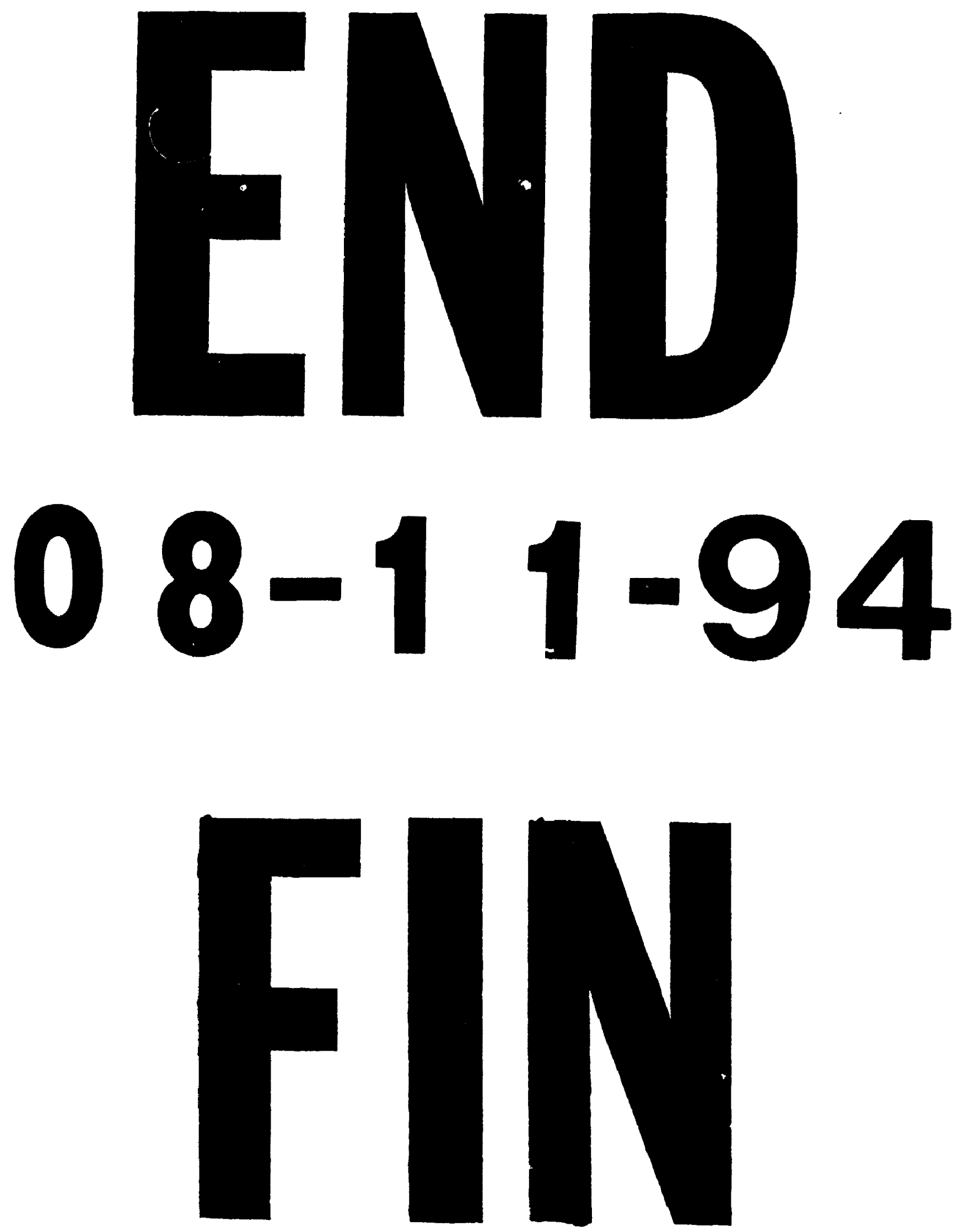